\title{
Dearomative Allylation of Naphthyl Cyanohydrins by Palladium Catalysis: Catalyst-Enhanced Site-Selectivity
}

Aika Yanagimoto, Masaaki Komatsuda, Kei Muto,* and Junichiro Yamaguchi*

Department of Applied Chemistry, Waseda University, 3-4-1 Ohkubo, Shinjuku, Tokyo 169-8555, Japan

E-mail: keimuto@aoni.waseda.jp (KM), junyamaguchi@waseda.jp (JY)

\section{Table of Contents}

1. General

2. Synthesis of Cyanophosphates

3. Pd-Catalyzed Dearomative Allylation of Cyanophosphates

4. Derivatization of Products

5. Effect of Parameters and Limitation

6. References

7. ${ }^{1} \mathrm{H},{ }^{13} \mathrm{C}$ and ${ }^{31} \mathrm{P}$ NMR Spectra
$\mathrm{S} 2$

S3-S11

S12-S17

S18-S20

S21-S23

S24

S25-S86 


\section{General}

Unless otherwise noted, all reactants or reagents including dry solvents were obtained from commercial suppliers and used as received. $\mathrm{Pd}(\mathrm{OAc})_{2}$ was obtained from FUJIFILM Wako Pure Chemical Corporation. Potassium allyltrifluoroborate (2a) was obtained from Frontier Scientific. Cesium carbonate was obtained from KANTO Chemical. 4-(Dimethylamino)phenyldiphenylphosphine (L1) and allyltributyltin (2b) were obtained from TCI. Tris(3,5-dimethylphenyl)phosphine $\quad(\mathbf{L 2}),{ }^{[1]} \quad$ tris(3,5-di-tert-butylphenyl)phosphine $\quad(\mathbf{L 3}),{ }^{[2]}$ tris(3,5-dimethoxyphenyl)phosphine (L4) ${ }^{[3]}$ and tris(3,5-bis(trifluoromethyl)phenyl)phosphine (L5) ${ }^{[4]}$ were synthesized according to the procedure in the reported literatures. Unless otherwise noted, all reactions were performed with dry solvents under an atmosphere of $\mathrm{N}_{2}$ in dried glassware using standard vacuum-line techniques. All dearomative reactions were performed in 8-mL glass vessel tubes equipped with a screw cap and heated (IKA Plate RCT digital) in a 16-well aluminum reaction block (IKA DB4.3 Block) unless otherwise noted. All work-up and purification procedures were carried out with reagent-grade solvents in air.

Analytical thin-layer chromatography (TLC) was performed using Silica-gel 70 TLC Plate-Wako $(0.25 \mathrm{~mm})$. The developed chromatogram was analyzed by UV lamp $(254 \mathrm{~nm})$. Flash column chromatography was performed with Biotage Isolera ${ }^{\circledR}$ equipped with Biotage SNAP Ultra columns or Biotage SNAP Ultra C18 columns. Preparative thin-layer chromatography (PTLC) was performed using Wakogel B5-F silica coated plates $(0.75 \mathrm{~mm})$ prepared in our laboratory. Basic alumina chromatography was performed using basic alumina, activated $(\mathrm{pH}=9.0-11.0)$ from FUJIFILM Wako Pure Chemical Corporation. High-resolution mass spectra were conducted on Thermo Fisher Scientific ExactivePlus Orbitrap (ESI and DART). Nuclear magnetic resonance (NMR) spectra were recorded on a JEOL JNM-ECS-400 $\left({ }^{1} \mathrm{H} 400 \mathrm{MHz},{ }^{13} \mathrm{C} 101 \mathrm{MHz},{ }^{31} \mathrm{P} 162 \mathrm{MHz}\right)$ spectrometer. Chemical shifts for ${ }^{1} \mathrm{H}$ NMR are expressed in parts per million (ppm) relative to tetramethylsilane ( $\delta$ $0.00 \mathrm{ppm})$. Chemical shifts for ${ }^{13} \mathrm{C}$ NMR are expressed in ppm relative to $\mathrm{CDCl}_{3}(\delta 77.0 \mathrm{ppm})$. Chemical shifts for ${ }^{31} \mathrm{P}$ NMR are expressed in ppm relative to $\mathrm{H}_{3} \mathrm{PO}_{4}(\delta 0.00 \mathrm{ppm})$ as an external standard. Data are reported as follows: chemical shift, multiplicity $(\mathrm{s}=$ singlet, $\mathrm{d}=$ doublet, $\mathrm{dd}=$ doublet of doublets, $\mathrm{t}=$ triplet, $\mathrm{dt}=$ doublet of triplets, $\mathrm{td}=$ triplet of doublets, $\mathrm{m}=$ multiplet ), coupling constant $(\mathrm{Hz})$, and integration. 


\section{Synthesis of Cyanophosphates}

\section{Synthesis of Cyano(4-methylnaphthalen-1-yl)methyl Diethyl Phosphate 1A}

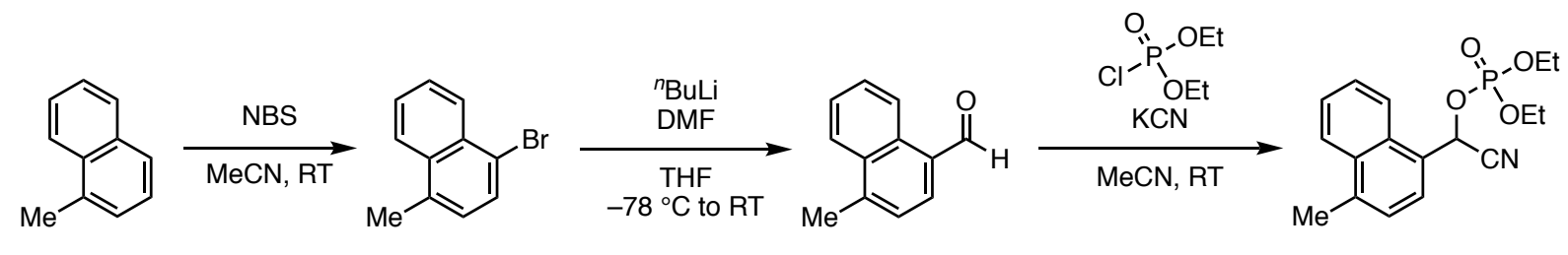

$1 \mathrm{~A}$

(Step 1) To a solution of 1-methlylnaphthalene (1.42 g, $10.0 \mathrm{mmol}, 1.0$ equiv) in MeCN (33 mL) was added $N$-bromosuccinimide (NBS: $2.31 \mathrm{~g}, 13.0 \mathrm{mmol}, 1.3$ equiv). After stirring the mixture for several hours with monitoring reaction progress with ${ }^{1} \mathrm{H} \mathrm{NMR}$, the solvent was evaporated in vacuo. Purification by Isolera ${ }^{\circledR}$ afforded 1-bromo-4-methylnaphthalene (2.15 g, 97\% yield).

(Step 2) A 100-mL two-necked flask containing a magnetic stirring bar was dried with a heat-gun in vacuo and filled with $\mathrm{N}_{2}$ after cooling to room temperature. To this flask was added 1-bromo-4-methylnaphthalene (1.56 g, $7.05 \mathrm{mmol}, 1.0$ equiv) in THF $(28 \mathrm{~mL})$. The mixture was cooled to $-78{ }^{\circ} \mathrm{C}$ and then $n$-butyllithium (1.59 $\mathrm{M}$ in hexane, $4.88 \mathrm{~mL}, 7.76 \mathrm{mmol}, 1.1$ equiv) was added slowly. The mixture was stirred at $-78{ }^{\circ} \mathrm{C}$ for $45 \mathrm{~min}$. To this mixture was slowly added DMF (1.09 mL, $14.1 \mathrm{mmol}, 1.5$ equiv). The mixture was further stirred at room temperature for $30 \mathrm{~min}$. The reaction was quenched with $\mathrm{NH}_{4} \mathrm{Cl}$ aq. and extracted three times with EtOAc. The combined organic layer was dried over $\mathrm{Na}_{2} \mathrm{SO}_{4}$, filtrated, and concentrated in vacuo. Purification by Isolera ${ }^{\circledR}$ (hexane/EtOAc = 15:1 to 2:1) afforded 4-methyl-1-naphthaldehyde (1.09 g, 91\% yield).

(Step 3) To a solution of 4-methyl-1-naphthaldehyde ( $860 \mathrm{mg}, 5.05 \mathrm{mmol}, 1.0$ equiv) in MeCN (50 $\mathrm{mL}$ ) were added potassium cyanide $(723 \mathrm{mg}, 11.1 \mathrm{mmol}, 2.2$ equiv) and diethyl chlorophosphate (1.05 $\mathrm{g}$, $6.06 \mathrm{mmol}, 1.2$ equiv). After stirring the mixture at room temperature for several hours with monitoring reaction progress with TLC, the reaction was quenched with $\mathrm{NaHCO}_{3}$ aq. and extracted three times with EtOAc. The combined organic layer was dried over $\mathrm{Na}_{2} \mathrm{SO}_{4}$, filtrated, and concentrated in vacuo. The residue was purified by Isolera ${ }^{\circledR}$ (hexane/EtOAc $=15: 1$ to $\left.2: 1\right)$ to afford $\mathbf{1 A}(1.55 \mathrm{~g}, 92 \%$ yield) as a yellow oil. ${ }^{1} \mathrm{H}$ NMR $\left(400 \mathrm{MHz}, \mathrm{CDCl}_{3}\right) \delta 8.26(\mathrm{~d}, J=8.4 \mathrm{~Hz}, 1 \mathrm{H}), 8.10(\mathrm{~d}, J=8.4 \mathrm{~Hz}, 1 \mathrm{H}), 7.73-7.59$ $(\mathrm{m}, 3 \mathrm{H}), 7.36(\mathrm{~d}, J=7.2 \mathrm{~Hz}, 1 \mathrm{H}), 6.63\left(\mathrm{~d}, J_{\mathrm{H}-\mathrm{P}}=8.4 \mathrm{~Hz}, 1 \mathrm{H}\right), 4.33-4.16(\mathrm{~m}, 2 \mathrm{H}), 4.02-3.84(\mathrm{~m}, 2 \mathrm{H})$, $2.74(\mathrm{~s}, 3 \mathrm{H}), 1.40(\mathrm{t}, J=7.2 \mathrm{~Hz}, 3 \mathrm{H}), 1.12(\mathrm{t}, J=7.2 \mathrm{~Hz}, 3 \mathrm{H}) ;{ }^{13} \mathrm{C} \mathrm{NMR}\left(101 \mathrm{MHz}, \mathrm{CDCl}_{3}\right) \delta 138.6$, $133.1,129.9,127.3,127.2,126.5,125.9\left(\mathrm{~d}, J_{\mathrm{C}-\mathrm{P}}=5.8 \mathrm{~Hz}\right), 125.8,125.1,123.4,116.3\left(\mathrm{~d}, J_{\mathrm{C}-\mathrm{P}}=4.8\right.$ $\mathrm{Hz}), 65.4\left(\mathrm{~d}, J_{\mathrm{C}-\mathrm{P}}=4.8 \mathrm{~Hz}\right), 64.9\left(\mathrm{~d}, J_{\mathrm{C}-\mathrm{P}}=5.7 \mathrm{~Hz}\right), 64.6\left(\mathrm{~d}, J_{\mathrm{C}-\mathrm{P}}=5.7 \mathrm{~Hz}\right), 19.8,16.0\left(\mathrm{~d}, J_{\mathrm{C}-\mathrm{P}}=6.7\right.$ $\mathrm{Hz}), 15.7\left(\mathrm{~d}, J_{\mathrm{C}-\mathrm{P}}=6.7 \mathrm{~Hz}\right) ;{ }^{31} \mathrm{P}$ NMR $\left(162 \mathrm{MHz}, \mathrm{CDCl}_{3}\right) \delta-3.70$; HRMS (DART) $\mathrm{m} / z$ calcd for $\mathrm{C}_{17} \mathrm{H}_{24} \mathrm{~N}_{2} \mathrm{O}_{4} \mathrm{P}\left[\mathrm{M}+\mathrm{NH}_{4}\right]^{+}: 351.1468$ found 351.1458 . 
Synthesis of Cyano(4-ethylnaphthalen-1-yl)methyl Diethyl Phosphate (1B)

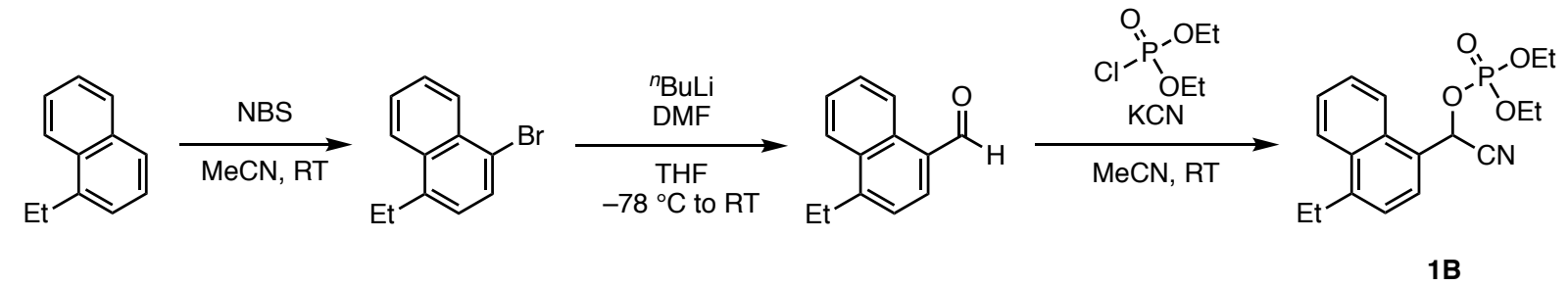

Following the synthetic procedure of 1A, compound 1B was obtained as a yellow oil (607 $\mathrm{mg}, 3.00$ mmol scale, Step 1: $86 \%$ yield; Step 2: 74\% yield; Step 3: 92\% yield). ${ }^{1} \mathrm{H}$ NMR (400 MHz, $\left.\mathrm{CDCl}_{3}\right) \delta$ $8.27(\mathrm{~d}, J=7.6 \mathrm{~Hz}, 1 \mathrm{H}), 8.16$ (d, $J=7.6 \mathrm{~Hz}, 1 \mathrm{H}), 7.74$ (d, $J=7.2 \mathrm{~Hz}, 1 \mathrm{H}), 7.69-7.59$ (m, 2H), 7.39 (d, $J=7.2 \mathrm{~Hz}, 1 \mathrm{H}), 6.63\left(\mathrm{~d}, J_{\mathrm{H}-\mathrm{P}}=8.4 \mathrm{~Hz}, 1 \mathrm{H}\right), 4.34-4.16(\mathrm{~m}, 2 \mathrm{H}), 4.02-3.84(\mathrm{~m}, 2 \mathrm{H}), 3.15(\mathrm{q}, J=7.6$ $\mathrm{Hz}, 2 \mathrm{H}), 1.45-1.36(\mathrm{~m}, 6 \mathrm{H}), 1.11(\mathrm{~m}, 3 \mathrm{H}) ;{ }^{13} \mathrm{C} \mathrm{NMR}\left(101 \mathrm{MHz}, \mathrm{CDCl}_{3}\right) \delta 144.4,132.2,130.1,127.4$, $127.0,126.4,125.7\left(\mathrm{~d}, J_{\mathrm{C}-\mathrm{P}}=5.8 \mathrm{~Hz}\right), 124.7,124.0,123.5,116.3\left(\mathrm{~d}, J_{\mathrm{C}-\mathrm{P}}=4.8 \mathrm{~Hz}\right), 65.4\left(\mathrm{~d}, J_{\mathrm{C}-\mathrm{P}}=4.8\right.$ $\mathrm{Hz}), 64.8\left(\mathrm{~d}, J_{\mathrm{C}-\mathrm{P}}=5.7 \mathrm{~Hz}\right), 64.6\left(\mathrm{~d}, J_{\mathrm{C}-\mathrm{P}}=5.8 \mathrm{~Hz}\right), 26.0,15.9\left(\mathrm{~d}, J_{\mathrm{C}-\mathrm{P}}=6.7 \mathrm{~Hz}\right), 15.6\left(\mathrm{~d}, J_{\mathrm{C}-\mathrm{P}}=6.7\right.$ $\mathrm{Hz}$ ), 14.7; ${ }^{31} \mathrm{P}$ NMR (162 MHz, $\mathrm{CDCl}_{3}$ ) $\delta-3.14$; HRMS (DART) $m / z$ calcd for $\mathrm{C}_{18} \mathrm{H}_{26} \mathrm{~N}_{2} \mathrm{O}_{4} \mathrm{P}[\mathrm{M}+$ $\left.\mathrm{NH}_{4}\right]^{+}: 365.1625$ found 365.1617 .

\section{Synthesis of Cyano(4-isobutylnaphthalen-1-yl)methyl Diethyl Phosphate (1C)}
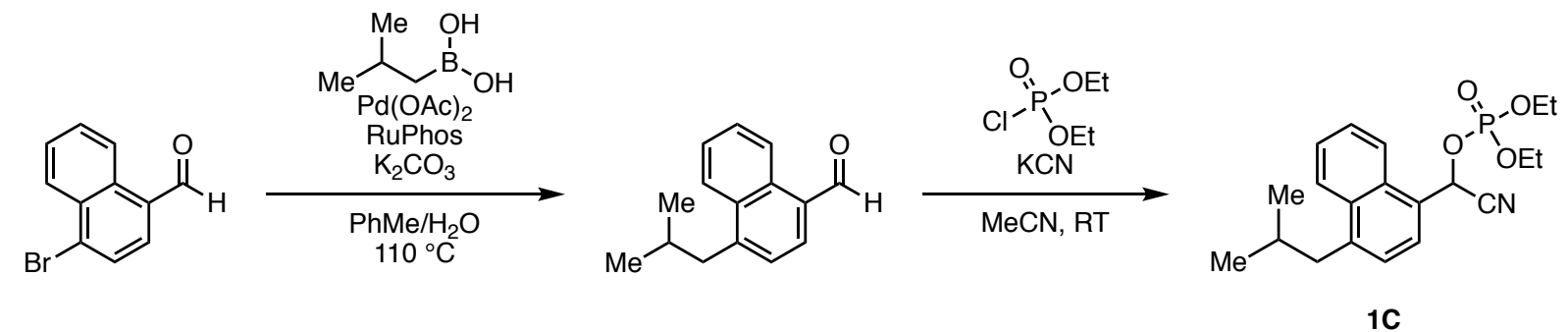

(Step 1) To a 25-mL glass vessel equipped with a screw cap containing a magnetic stirring bar were added potassium carbonate $\left(415 \mathrm{mg}, 3.00 \mathrm{mmol}, 3.0\right.$ equiv), 4-bromo-1-naphthaldehyde ${ }^{[5]}$ (235 mg, $1.00 \mathrm{mmol}, 1.0$ equiv), isobutylboronic acid (153 mg, $1.50 \mathrm{mmol}, 1.5$ equiv), $\mathrm{Pd}(\mathrm{OAc})_{2}(8.98 \mathrm{mg}, 40.0$ $\mu \mathrm{mol}, 4.0 \mathrm{~mol} \%$ ), and RuPhos (37.3 mg, $80.0 \mu \mathrm{mol}, 8.0 \mathrm{~mol} \%)$. The vessel was placed under vacuum and refilled $\mathrm{N}_{2}$ gas three times, and then added toluene $(3.0 \mathrm{~mL})$ and $\mathrm{H}_{2} \mathrm{O}(1.5 \mathrm{~mL})$. The vessel was sealed with a screw cap and then heated at $110^{\circ} \mathrm{C}$ in an oil bath for $18 \mathrm{~h}$ with stirring. After cooling the reaction mixture to room temperature, the mixture was passed through a short silica-gel pad with EtOAc as an eluent, and then concentrated in vacuo. The residue was purified by Isolera ${ }^{\circledR}$ (hexane to hexane/EtOAc $=5: 1)$ to afford 4-isobutyl-1-naphthaldehyde $(175 \mathrm{mg}, 82 \%$ yield $)$ as a yellow oil.

(Step 2) To a solution of 4-isobutyl-1-naphthaldehyde (175 mg, $0.823 \mathrm{mmol}, 1.0$ equiv) in $\mathrm{MeCN}$ $(8.2 \mathrm{~mL})$ were added potassium cyanide $(118 \mathrm{mg}, 1.81 \mathrm{mmol}, 2.2$ equiv) and diethyl chlorophosphate (142 $\mu \mathrm{L}, 0.988 \mathrm{mmol}, 1.2$ equiv). After stirring the mixture at room temperature for several hours with monitoring reaction progress with TLC, the reaction was quenched with $\mathrm{NaHCO}_{3}$ aq. and extracted three times with EtOAc. The combined organic layer was dried over $\mathrm{Na}_{2} \mathrm{SO}_{4}$, filtrated, and 
concentrated in vacuo. The residue was purified by Isolera ${ }^{\circledR}$ (hexane/EtOAc $=15: 1$ to 2:1) to afford 1C (264 mg, 85\% yield) as a colorless oil. ${ }^{1} \mathrm{H}$ NMR (400 MHz, $\left.\mathrm{CDCl}_{3}\right) \delta 8.26(\mathrm{~d}, J=8.4 \mathrm{~Hz}, 1 \mathrm{H})$, $8.12(\mathrm{~d}, J=8.4 \mathrm{~Hz}, 1 \mathrm{H}), 7.71(\mathrm{~d}, J=7.2 \mathrm{~Hz}, 1 \mathrm{H}), 7.68-7.57(\mathrm{~m}, 2 \mathrm{H}), 7.32(\mathrm{~d}, J=7.2 \mathrm{~Hz}, 1 \mathrm{H}), 6.63(\mathrm{~d}$, $\left.J_{\mathrm{H}-\mathrm{P}}=8.8 \mathrm{~Hz}, 1 \mathrm{H}\right), 4.33-4.15(\mathrm{~m}, 2 \mathrm{H}), 4.01-3.83(\mathrm{~m}, 2 \mathrm{H}), 2.96(\mathrm{~d}, J=7.2 \mathrm{~Hz}, 2 \mathrm{H}), 2.12-2.00(\mathrm{~m}, 1 \mathrm{H})$, $1.40(\mathrm{t}, J=7.2 \mathrm{~Hz}, 3 \mathrm{H}), 1.10(\mathrm{t}, J=7.2 \mathrm{~Hz}, 3 \mathrm{H}), 0.98(\mathrm{~d}, J=7.2 \mathrm{~Hz}, 3 \mathrm{H}), 0.97(\mathrm{~d}, J=7.2 \mathrm{~Hz}, 3 \mathrm{H}) ;{ }^{13} \mathrm{C}$ NMR (101 MHz, $\left.\mathrm{CDCl}_{3}\right) \delta 142.1,132.7,130.3,127.1,127.0,126.3,126.2,125.9$ (d, $\left.J_{\mathrm{C}-\mathrm{P}}=5.8 \mathrm{~Hz}\right)$, $125.2,123.5,116.4\left(\mathrm{~d}, J_{\mathrm{C}-\mathrm{P}}=4.8 \mathrm{~Hz}\right), 65.5\left(\mathrm{~d}, J_{\mathrm{C}-\mathrm{P}}=4.8 \mathrm{~Hz}\right), 64.9\left(\mathrm{~d}, J_{\mathrm{C}-\mathrm{P}}=6.7 \mathrm{~Hz}\right), 64.6\left(\mathrm{~d}, J_{\mathrm{C}-\mathrm{P}}=\right.$ $5.8 \mathrm{~Hz}), 42.7,29.5,22.75,22.72,16.0\left(\mathrm{~d}, J_{\mathrm{C}-\mathrm{P}}=6.7 \mathrm{~Hz}\right), 15.7\left(\mathrm{~d}, J_{\mathrm{C}-\mathrm{P}}=7.6 \mathrm{~Hz}\right) ;{ }^{31} \mathrm{P} \mathrm{NMR}(162 \mathrm{MHz}$, $\mathrm{CDCl}_{3}$ ) $\delta$-3.59; HRMS (DART) $m / z$ calcd for $\mathrm{C}_{20} \mathrm{H}_{30} \mathrm{~N}_{2} \mathrm{O}_{4} \mathrm{P}\left[\mathrm{M}+\mathrm{NH}_{4}\right]^{+}: 393.1938$ found 393.1932.

\section{Synthesis of Cyano(4-isopropylnaphthalen-1-yl)methyl Diethyl Phosphate (1D)}<smiles>Brc1cccc2ccccc12</smiles>

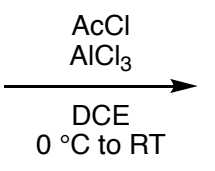<smiles>CC(=O)c1ccc(Br)c2ccccc12</smiles>
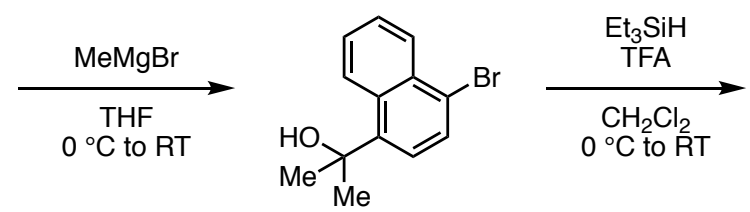<smiles>CC(C)c1ccc(Br)c2ccccc12</smiles>
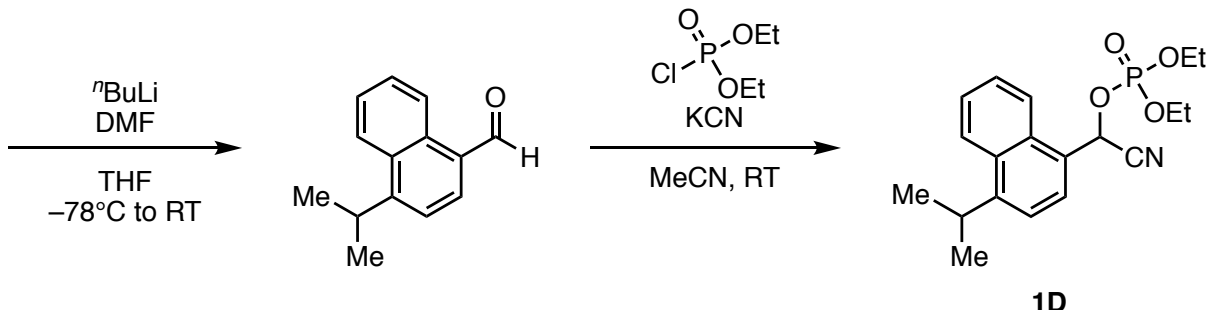

(Step 1) To a solution of 1-bromonaphthalene (1.12 mL, $8.00 \mathrm{mmol}, 1.0$ equiv) and acetyl chloride (628 $\mu \mathrm{L}, 8.80 \mathrm{mmol}, 1.1$ equiv) in 1,2-dichloroethane $(25 \mathrm{~mL})$ was added aluminum chloride $(2.40 \mathrm{~g}$, $18.0 \mathrm{mmol}, 2.3$ equiv) portionwise at $0{ }^{\circ} \mathrm{C}$. The mixture was stirred at room temperature for $24 \mathrm{~h}$. The reaction mixture was poured into ice-water $(50 \mathrm{~mL})$. The mixture was extracted three times with EtOAc. The combined organic layer was dried over $\mathrm{MgSO}_{4}$, filtrated, and concentrated in vacuo. The residue was purified by Isolera $^{\circledR}$ (hexane/EtOAc $=15: 1$ to $1: 1$ ) to afford 1-(4-bromonaphthalen-1-yl)ethan-1-one (1.16 g, 58\% yield) as an orange oil.

(Step 2) A 100-mL round-bottom flask containing a magnetic stirring bar, was dried with a heat-gun in vacuo and filled with $\mathrm{N}_{2}$ after cooling to room temperature. To this flask was added 1-(4-bromonaphthalen-1-yl)ethan-1-one (1.50 g, $6.00 \mathrm{mmol}, 1.0$ equiv) in THF (20 mL). The mixture was cooled to $0{ }^{\circ} \mathrm{C}$ and then $\mathrm{MeMgBr}(1.07 \mathrm{M}$ in THF, $11.3 \mathrm{~mL}, 2.0$ equiv) was added slowly. The mixture was stirred at room temperature overnight. The reaction was quenched with $\mathrm{NH}_{4} \mathrm{Cl}$ aq. and extracted three times with EtOAc. The combined organic layer was dried over $\mathrm{Na}_{2} \mathrm{SO}_{4}$, filtrated, and concentrated in vacuo. Purification by Isolera $^{\circledR}$ (hexane/EtOAc $=15: 1$ to $1: 1$ ) to afford 2-(4-bromonaphthalen-1-yl)propan-2-ol (1.02 g, 65\% yield) as a yellow oil.

(Step 3) To a 100-mL round-bottom flask containing 2-(4-bromonaphthalen-1-yl)propan-2-ol (1.02 g, $3.86 \mathrm{mmol}, 1.0$ equiv) in $\mathrm{CH}_{2} \mathrm{Cl}_{2}(30 \mathrm{~mL})$ and triethylsilane $(677 \mu \mathrm{L}, 4.25 \mathrm{mmol}, 1.1$ equiv) was added 
TFA (3.25 mL, $42.5 \mathrm{mmol}, 11$ equiv) at $0{ }^{\circ} \mathrm{C}$. The mixture was further stirred at room temperature overnight. The reaction was quenched with $\mathrm{NaHCO}_{3}$ aq. and extracted three times with EtOAc. The combined organic layer was dried over $\mathrm{Na}_{2} \mathrm{SO}_{4}$, filtrated, and concentrated in vacuo. Purification by Isolera $^{\circledR}$ (hexane to hexane/EtOAc $\left.=5: 1\right)$ afforded 1-bromo-4-isopropylnaphthalene $(873 \mathrm{mg}, 91 \%$ yield) as a colorless oil.

(Step 4) A 100-mL two-necked flask containing a magnetic stirring bar was dried with a heat-gun in vacuo and filled with $\mathrm{N}_{2}$ after cooling to room temperature. To this flask was added 1-bromo-4-isopropylnaphthalene (372 mg, $1.49 \mathrm{mmol}, 1.0$ equiv) in THF (5.0 mL). The mixture was cooled to $-78^{\circ} \mathrm{C}$ and then $n$-butyllithium ( $1.55 \mathrm{M}$ in hexane, $1.06 \mathrm{~mL}, 1.1$ equiv) was added slowly. The mixture was stirred at $-78{ }^{\circ} \mathrm{C}$ for $45 \mathrm{~min}$. To this mixture was slowly added DMF ( $173 \mu \mathrm{L}, 2.24 \mathrm{mmol}$, 1.5 equiv). The mixture was further stirred at room temperature for $30 \mathrm{~min}$. The reaction was quenched with $\mathrm{NH}_{4} \mathrm{Cl}$ aq. and extracted three times with EtOAc. The combined organic layer was dried over $\mathrm{Na}_{2} \mathrm{SO}_{4}$, filtrated, and concentrated in vacuo. Purification by Isolera ${ }^{\circledR}$ (hexane to hexane/EtOAc $=3: 1$ ) afforded 4-isopropyl-1-naphthaldehyde (126 mg, 43\% yield) as a yellow oil.

(Step 5) To a solution of 4-isopropyl-1-naphthaldehyde (126 mg, $0.638 \mathrm{mmol}, 1.0$ equiv) in $\mathrm{MeCN}$ $(6.4 \mathrm{~mL})$ were added potassium cyanide $(91.3 \mathrm{mg}, 1.40 \mathrm{mmol}, 2.2$ equiv) and diethyl chlorophosphate (110 $\mu \mathrm{L}, 0.765 \mathrm{mmol}, 1.2$ equiv). After stirring the mixture at room temperature for several hours with monitoring reaction progress with TLC, the reaction was quenched with $\mathrm{NaHCO}_{3}$ aq. and extracted three times with EtOAc. The combined organic layer was dried over $\mathrm{Na}_{2} \mathrm{SO}_{4}$, filtrated, and concentrated in vacuo. The residue was purified by Isolera ${ }^{\circledR}$ (hexane/EtOAc $=15: 1$ to $\left.2: 1\right)$ to afford 1D $(183 \mathrm{mg}, 79 \%$ yield) as a colorless oil. ${ }^{1} \mathrm{H}$ NMR $\left(400 \mathrm{MHz}, \mathrm{CDCl}_{3}\right) \delta 8.27(\mathrm{~d}, J=7.6 \mathrm{~Hz}, 1 \mathrm{H}), 8.24(\mathrm{~d}, J=7.6 \mathrm{~Hz}$, $1 \mathrm{H}), 7.77(\mathrm{~d}, J=7.2 \mathrm{~Hz}, 1 \mathrm{H}), 7.69-7.58(\mathrm{~m}, 2 \mathrm{H}), 7.46(\mathrm{~d}, J=7.2 \mathrm{~Hz}, 1 \mathrm{H}), 6.63\left(\mathrm{~d}, J_{\mathrm{H}-\mathrm{P}}=8.4 \mathrm{~Hz}, 1 \mathrm{H}\right)$, 4.33-4.16 (m, 2H), 4.02-3.85 (m, 2H), 3.85-3.72 (m, 1H), 1.46-1.36 (m, 9H), $1.11(\mathrm{t}, J=7.2 \mathrm{~Hz}$, $3 \mathrm{H}) ;{ }^{13} \mathrm{C} \mathrm{NMR}\left(101 \mathrm{MHz}, \mathrm{CDCl}_{3}\right) \delta 148.8,131.8,130.2,127.4,126.9,126.4,125.5$ (d, $\left.J_{\mathrm{C}-\mathrm{P}}=5.8 \mathrm{~Hz}\right)$, 124.3, 123.6, 121.0, $116.3\left(\mathrm{~d}, J_{\mathrm{C}-\mathrm{P}}=4.8 \mathrm{~Hz}\right), 65.5\left(\mathrm{~d}, J_{\mathrm{C}-\mathrm{P}}=4.7 \mathrm{~Hz}\right), 64.8\left(\mathrm{~d}, J_{\mathrm{C}-\mathrm{P}}=5.8 \mathrm{~Hz}\right), 64.6(\mathrm{~d}$, $\left.J_{\mathrm{C}-\mathrm{P}}=5.8 \mathrm{~Hz}\right), 28.7,23.4,23.3,15.9\left(\mathrm{~d}, J_{\mathrm{C}-\mathrm{P}}=7.7 \mathrm{~Hz}\right), 15.6\left(\mathrm{~d}, J_{\mathrm{C}-\mathrm{P}}=6.7 \mathrm{~Hz}\right) ;{ }^{31} \mathrm{P} \mathrm{NMR}(162 \mathrm{MHz}$, $\left.\mathrm{CDCl}_{3}\right) \delta-3.62$; HRMS (DART) $\mathrm{m} / z$ calcd for $\mathrm{C}_{19} \mathrm{H}_{28} \mathrm{~N}_{2} \mathrm{O}_{4} \mathrm{P}\left[\mathrm{M}+\mathrm{NH}_{4}\right]^{+}: 379.1781$ found 379.1776 .

\section{Synthesis of Cyano(4-cyclopropylnaphthalen-1-yl)methyl Diethyl Phosphate (1E)}

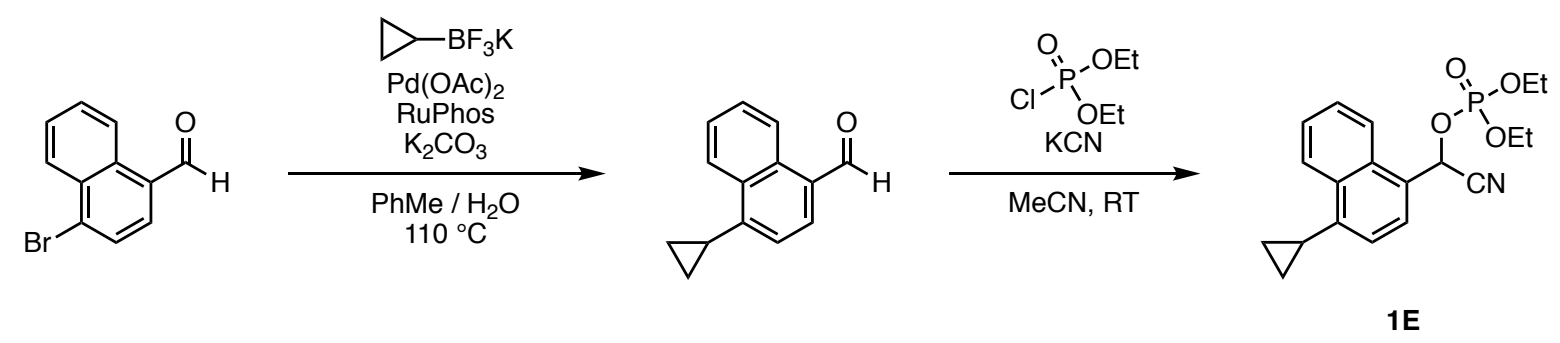

Following the synthetic procedure of 1C, compound 1E was obtained as a yellow oil $(207 \mathrm{mg}$, $0.696 \mathrm{mmol}$ scale, Step 1: 87\% yield; Step 2: 83\% yield). ${ }^{1} \mathrm{H}$ NMR $\left(400 \mathrm{MHz}, \mathrm{CDCl}_{3}\right) \delta 8.57-8.48(\mathrm{~m}$, 
$1 \mathrm{H}), 8.30-8.21(\mathrm{~m}, 1 \mathrm{H}), 7.71(\mathrm{~d}, J=7.6 \mathrm{~Hz}, 1 \mathrm{H}), 7.69-7.62(\mathrm{~m}, 2 \mathrm{H}), 7.29(\mathrm{~d}, J=7.6 \mathrm{~Hz}, 1 \mathrm{H}), 6.62(\mathrm{~d}$, $\left.J_{\mathrm{H}-\mathrm{P}}=8.4 \mathrm{~Hz}, 1 \mathrm{H}\right), 4.33-4.16(\mathrm{~m}, 2 \mathrm{H}), 4.02-3.84(\mathrm{~m}, 2 \mathrm{H}), 2.43-2.32(\mathrm{~m}, 1 \mathrm{H}), 1.40(\mathrm{t}, J=7.2 \mathrm{~Hz}, 3 \mathrm{H})$, 1.17-1.08 (m, 5H), 0.84-0.77 (m, 2H); ${ }^{13} \mathrm{C} \mathrm{NMR}\left(101 \mathrm{MHz}, \mathrm{CDCl}_{3}\right) \delta 143.2,133.8,129.7,127.11$, 127.07, 126.3, $125.7\left(\mathrm{~d}, J_{\mathrm{C}-\mathrm{P}}=4.8 \mathrm{~Hz}\right), 125.3,123.2,122.7,116.2\left(\mathrm{~d}, J_{\mathrm{C}-\mathrm{P}}=5.7 \mathrm{~Hz}\right), 65.3\left(\mathrm{~d}, J_{\mathrm{C}-\mathrm{P}}=\right.$ $4.8 \mathrm{~Hz}), 64.7\left(\mathrm{~d}, J_{\mathrm{C}-\mathrm{P}}=5.7 \mathrm{~Hz}\right), 64.5\left(\mathrm{~d}, J_{\mathrm{C}-\mathrm{P}}=5.8 \mathrm{~Hz}\right), 15.8\left(\mathrm{~d}, J_{\mathrm{C}-\mathrm{P}}=6.7 \mathrm{~Hz}\right), 15.5\left(\mathrm{~d}, J_{\mathrm{C}-\mathrm{P}}=6.7 \mathrm{~Hz}\right)$, 13.3, 6.62, 6.60; ${ }^{31} \mathrm{P}$ NMR (162 MHz, $\mathrm{CDCl}_{3}$ ) $\delta-4.43$; HRMS (DART) $m / z$ calcd for $\mathrm{C}_{19} \mathrm{H}_{26} \mathrm{~N}_{2} \mathrm{O}_{4} \mathrm{P}$ [M $\left.+\mathrm{NH}_{4}\right]^{+}: 377.1625$ found 377.1617 .

\section{Synthesis of (4-Allylnaphthalen-1-yl)(cyano)methyl Diethyl Phosphate (1F)}
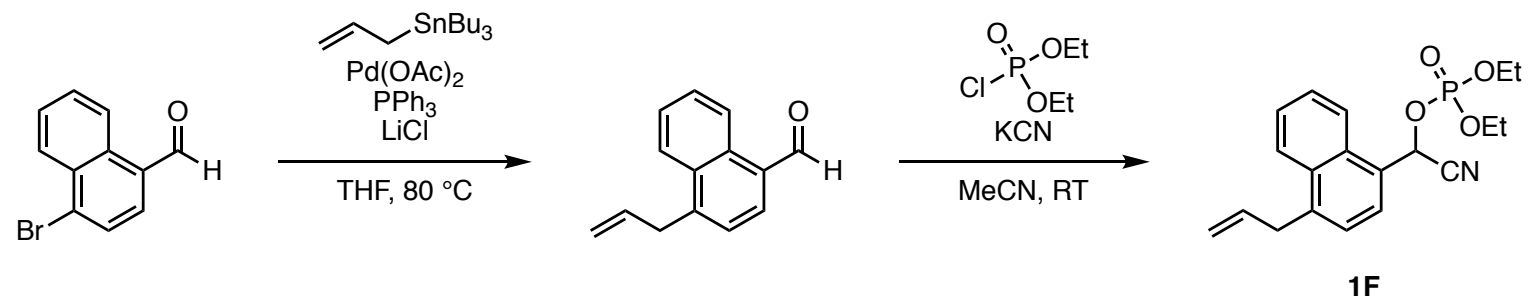

(Step 1) A 20-mL glass vessel equipped with J. Young ${ }^{\circledR}$ O-ring tap containing a magnetic stirring bar and lithium chloride (95.4 mg, $2.25 \mathrm{mmol}, 5.0$ equiv) was dried with a heat-gun in vacuo and filled with $\mathrm{N}_{2}$ after cooling to room temperature. To this vessel were added $\mathrm{Pd}(\mathrm{OAc})_{2}(10.1 \mathrm{mg}, 45.0 \mu \mathrm{mol}$, $\left.10 \mathrm{~mol}^{\%}\right), \mathrm{PPh}_{3}$ (47.2mg, $0.180 \mathrm{mmol}, 40 \mathrm{~mol} \%$ ) and 4-bromo-1-naphthaldehyde (106 mg, 0.450 mmol, 1.0 equiv). The vessel was placed under vacuum and refilled $\mathrm{N}_{2}$ gas three times, and then added allyltributyltin $(152 \mu \mathrm{L}, 0.495 \mathrm{mmol}, 1.1$ equiv) and THF $(4.5 \mathrm{~mL})$. The vessel was sealed with O-ring tap and then heated at $80{ }^{\circ} \mathrm{C}$ in an oil bath for $22 \mathrm{~h}$ with stirring. After cooling the reaction mixture to room temperature, the mixture was passed through a short silica-gel pad with EtOAc as an eluent, and then concentrated in vacuo. The residue was purified by Isolera ${ }^{\circledR}$ (hexane to hexane/EtOAc $=5: 1$ ) to afford 4-allyl-1-naphthaldehyde (66.0 mg, $75 \%$ yield) as a colorless oil.

(Step 2) To a solution of 4-allyl-1-naphthaldehyde (66.0 mg, $0.336 \mathrm{mmol}, 1.0$ equiv) in $\mathrm{MeCN}$ (3.4 $\mathrm{mL}$ ) were added potassium cyanide $(48.2 \mathrm{mg}, 0.740 \mathrm{mmol}, 2.2$ equiv) and diethyl chlorophosphate (58.0 $\mu \mathrm{L}, 0.404 \mathrm{mmol}, 1.2$ equiv). After stirring the mixture at room temperature for several hours with monitoring reaction progress with TLC, the reaction was quenched with $\mathrm{NaHCO}_{3}$ aq. and extracted three times with EtOAc. The combined organic layer was dried over $\mathrm{Na}_{2} \mathrm{SO}_{4}$, filtrated, and concentrated in vacuo. The residue was purified by Isolera ${ }^{\circledR}$ (hexane/EtOAc $=15: 1$ to $2: 1$ ) to afford $\mathbf{1 F}$ (100 mg, 83\% yield) as a colorless oil. ${ }^{1} \mathrm{H}$ NMR $\left(400 \mathrm{MHz}, \mathrm{CDCl}_{3}\right) \delta 8.27(\mathrm{~d}, J=8.0 \mathrm{~Hz}, 1 \mathrm{H}), 8.13$ (d, $J=8.0 \mathrm{~Hz}, 1 \mathrm{H}), 7.74(\mathrm{~d}, J=7.2 \mathrm{~Hz}, 1 \mathrm{H}), 7.69-7.58(\mathrm{~m}, 2 \mathrm{H}), 7.40(\mathrm{~d}, J=7.2 \mathrm{~Hz}, 1 \mathrm{H}), 6.64\left(\mathrm{~d}, J_{\mathrm{H}-\mathrm{P}}=\right.$ $8.8 \mathrm{~Hz}, 1 \mathrm{H}), 6.16-6.03(\mathrm{~m}, 1 \mathrm{H}), 5.19-5.05(\mathrm{~m}, 2 \mathrm{H}), 4.33-4.17(\mathrm{~m}, 2 \mathrm{H}), 4.02-3.84(\mathrm{~m}, 4 \mathrm{H}), 1.40(\mathrm{t}, J$ $=7.2 \mathrm{~Hz}, 3 \mathrm{H}), 1.12(\mathrm{t}, J=7.2 \mathrm{~Hz}, 3 \mathrm{H}) ;{ }^{13} \mathrm{C} \mathrm{NMR}\left(101 \mathrm{MHz}, \mathrm{CDCl}_{3}\right) \delta 140.3,135.9,132.4,130.1$, $127.25,127.17,126.5,126.3\left(\mathrm{~d}, J_{\mathrm{C}-\mathrm{P}}=5.7 \mathrm{~Hz}\right), 125.4,125.1,123.5,116.9,116.2\left(\mathrm{~d}, J_{\mathrm{C}-\mathrm{P}}=4.8 \mathrm{~Hz}\right)$, $65.3\left(\mathrm{~d}, J_{\mathrm{C}-\mathrm{P}}=4.8 \mathrm{~Hz}\right), 64.9\left(\mathrm{~d}, J_{\mathrm{C}-\mathrm{P}}=5.8 \mathrm{~Hz}\right), 64.6\left(\mathrm{~d}, J_{\mathrm{C}-\mathrm{P}}=6.7 \mathrm{~Hz}\right), 37.3,15.9\left(\mathrm{~d}, J_{\mathrm{C}-\mathrm{P}}=6.7 \mathrm{~Hz}\right)$, 
$15.7\left(\mathrm{~d}, J_{\mathrm{C}-\mathrm{P}}=7.6 \mathrm{~Hz}\right) ;{ }^{31} \mathrm{P}$ NMR $\left(162 \mathrm{MHz}, \mathrm{CDCl}_{3}\right) \delta-3.70$; HRMS (DART) $\mathrm{m} / \mathrm{z}$ calcd for $\mathrm{C}_{19} \mathrm{H}_{26} \mathrm{~N}_{2} \mathrm{O}_{4} \mathrm{P}\left[\mathrm{M}+\mathrm{NH}_{4}\right]^{+}: 377.1625$ found 377.1618 .

\section{Synthesis of (4-(1,3-Dioxolan-2-yl)naphthalen-1-yl)(cyano)methyl Diethyl Phosphate (1G)}

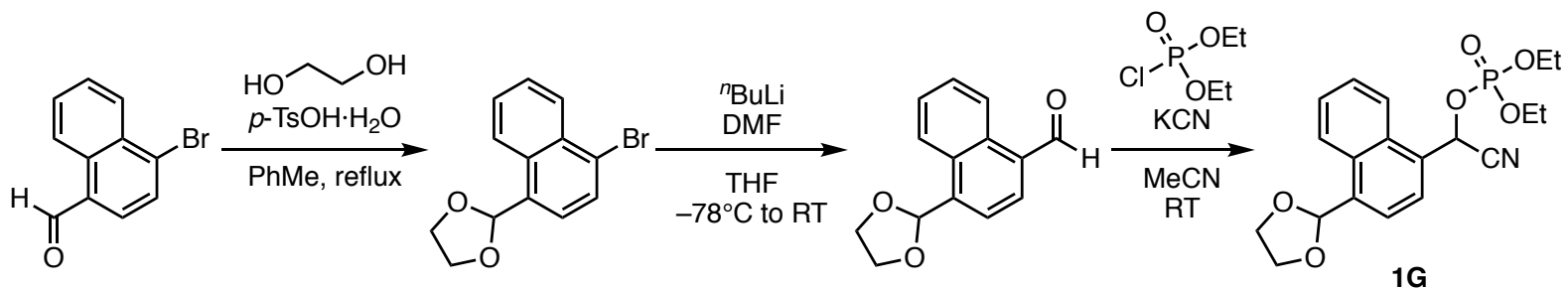

(Step 1) To a round-bottom flask containing 4-bromo-1-naphthaldehyde (423 mg, $1.80 \mathrm{mmol}, 1.0$ equiv) and $p$-toluenesulfonic acid monohydrate $(3.42 \mathrm{mg}, 18.0 \mu \mathrm{mol}, 1.0 \mathrm{~mol} \%)$ in toluene $(6.0 \mathrm{~mL})$ was added ethylene glycol $(292 \mu \mathrm{L}, 5.22 \mathrm{mmol}, 2.9$ equiv). The reaction mixture was refluxed (in an oil bath) in a Dean-Stark apparatus for $16 \mathrm{~h}$. After cooling to room temperature, the mixture was quenched with $\mathrm{NaHCO}_{3}$ aq. and extracted three times with EtOAc. The combined organic layer was dried over $\mathrm{Na}_{2} \mathrm{SO}_{4}$, filtrated, and concentrated in vacuo. The residue was purified by Isolera ${ }^{\circledR}$ (hexane to hexane/EtOAc $=5: 1)$ to afford 2-(4-bromonaphthalen-1-yl)-1,3-dioxolane (470 $\mathrm{mg}, 94 \%$ yield) as a yellow oil.

(Step 2) A 100-mL two-necked flask containing a magnetic stirring bar was dried with a heat-gun in vacuo and filled with $\mathrm{N}_{2}$ after cooling to room temperature. To this flask was added 2-(4-bromonaphthalen-1-yl)-1,3-dioxolane (335 mg, $1.20 \mathrm{mmol}, 1.0$ equiv) in THF (4.0 mL). The mixture was cooled to $-78{ }^{\circ} \mathrm{C}$ and then $n$-butyllithium (1.51 M in hexane, $874 \mu \mathrm{L}, 1.1$ equiv) was added slowly. The mixture was stirred at $-78{ }^{\circ} \mathrm{C}$ for $45 \mathrm{~min}$. To this mixture was slowly added DMF (139 $\mu \mathrm{L}, 1.80 \mathrm{mmol}, 1.5$ equiv). The mixture was further stirred at room temperature for $30 \mathrm{~min}$. The reaction was quenched with $\mathrm{NH}_{4} \mathrm{Cl}$ aq. and extracted three times with EtOAc. The combined organic layer was dried over $\mathrm{Na}_{2} \mathrm{SO}_{4}$, filtrated, and concentrated in vacuo. The residue was purified by Isolera $^{\circledR}($ hexane/EtOAc $=15: 1$ to $2: 1)$ to afford 4-(1,3-dioxolan-2-yl)-1-naphthaldehyde $(179 \mathrm{mg}, 65 \%$ yield) as a white solid.

(Step 3) To a solution of 4-(1,3-dioxolan-2-yl)-1-naphthaldehyde (179 mg, $0.785 \mathrm{mmol}, 1.0$ equiv) in $\mathrm{MeCN}(7.9 \mathrm{~mL})$ were added potassium cyanide $(112 \mathrm{mg}, 1.73 \mathrm{mmol}, 2.2$ equiv) and diethyl chlorophosphate (135 $\mu \mathrm{L}, 0.942 \mathrm{mmol}, 1.2$ equiv). After stirring the mixture at room temperature for several hours with monitoring reaction progress with TLC, the reaction was quenched with $\mathrm{NaHCO}_{3}$ aq. and extracted three times with EtOAc. The combined organic layer was dried over $\mathrm{Na}_{2} \mathrm{SO}_{4}$, filtrated, and concentrated in vacuo. The residue was purified by Isolera ${ }^{\circledR}$ (hexane/EtOAc $=15: 1$ to 2:1) to afford $1 \mathrm{G}$ (295 mg, 96\% yield) as a yellow oil. ${ }^{1} \mathrm{H}$ NMR (400 MHz, $\left.\mathrm{CDCl}_{3}\right) \delta 8.32(\mathrm{dd}, J=7.6$, $2.0 \mathrm{~Hz}, 1 \mathrm{H}), 8.27(\mathrm{dd}, J=7.6,2.0 \mathrm{~Hz}, 1 \mathrm{H}), 7.84-7.79(\mathrm{~m}, 2 \mathrm{H}), 7.70-7.62(\mathrm{~m}, 2 \mathrm{H}), 6.67\left(\mathrm{~d}, J_{\mathrm{H}-\mathrm{P}}=9.2\right.$ $\mathrm{Hz}, 1 \mathrm{H}), 6.50$ (s, 1H), 4.33-4.16 (m, 6H), 4.02-3.86 (m, 2H), 1.50-1.35 (m, 3H), 1.18-1.04 (m, 3H); ${ }^{13} \mathrm{C}$ NMR $\left(101 \mathrm{MHz}, \mathrm{CDCl}_{3}\right) \delta 136.9,131.5,130.1,128.8\left(\mathrm{~d}, J_{\mathrm{C}-\mathrm{P}}=5.8 \mathrm{~Hz}\right), 127.4,127.0,126.6$, 
$125.1,123.3,122.5,116.1\left(\mathrm{~d}, J_{\mathrm{C}-\mathrm{P}}=4.8 \mathrm{~Hz}\right), 101.4,65.4,65.2\left(\mathrm{~d}, J_{\mathrm{C}-\mathrm{P}}=4.8 \mathrm{~Hz}\right), 65.0\left(\mathrm{~d}, J_{\mathrm{C}-\mathrm{P}}=5.7\right.$ $\mathrm{Hz}), 64.7\left(\mathrm{~d}, J_{\mathrm{C}-\mathrm{P}}=5.7 \mathrm{~Hz}\right), 16.0\left(\mathrm{~d}, J_{\mathrm{C}-\mathrm{P}}=6.7 \mathrm{~Hz}\right), 15.7\left(\mathrm{~d}, J_{\mathrm{C}-\mathrm{P}}=6.7 \mathrm{~Hz}\right)$ (one peak is missing due to overlapping); ${ }^{31} \mathrm{P}$ NMR $\left(162 \mathrm{MHz}, \mathrm{CDCl}_{3}\right) \delta-3.22$; HRMS (DART) $m / z$ calcd for $\mathrm{C}_{19} \mathrm{H}_{26} \mathrm{~N}_{2} \mathrm{O}_{6} \mathrm{P}[\mathrm{M}+$ $\left.\mathrm{NH}_{4}\right]^{+}: 409.1523$ found 409.1539.

\section{Synthesis of Cyano(4-(2-methoxyethyl)naphthalen-1-yl)methyl Diethyl Phosphate (1H)}
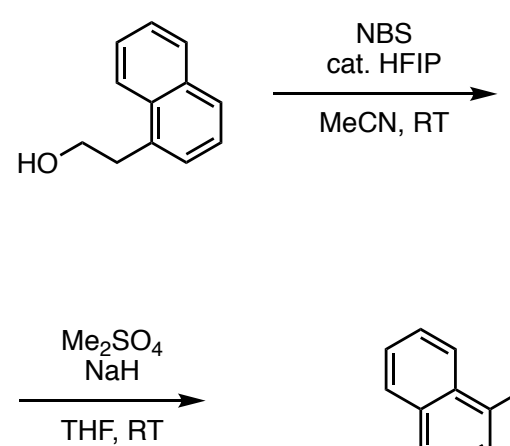

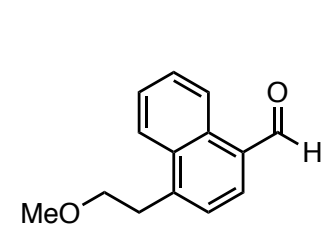<smiles>OCCc1ccc(Br)c2ccccc12</smiles>

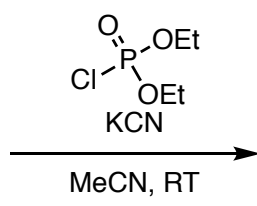

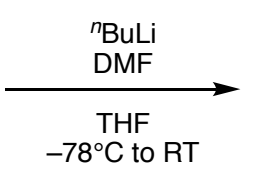<smiles>O=Cc1ccc(CCO)c2ccccc12</smiles>

S1

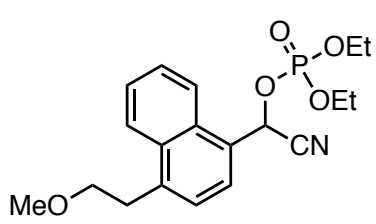

$1 \mathrm{H}$

(Step 1) To a solution of 2-(naphthalen-1-yl)ethan-1-ol (861 mg, $5.00 \mathrm{mmol}, 1.0$ equiv) in $\mathrm{MeCN}$ (25 mL) were added NBS (979 mg, $5.50 \mathrm{mmol}, 1.1$ equiv) and HFIP (50.0 $\mu \mathrm{L}, 0.46 \mathrm{mmol}, 9.0 \mathrm{~mol} \%$ ). After stirring the mixture overnight, the solvent was evaporated in vacuo. Purification by Isolera ${ }^{\circledR}$ (hexane/EtOAc $=20: 1$ to 2:1) afforded 2-(4-bromonaphthalen-1-yl)ethan-1-ol (1.05 g, 84\% yield) as a brown oil.

(Step 2) A 100-mL two-necked flask containing a magnetic stirring bar was dried with a heat-gun in vacuo and filled with $\mathrm{N}_{2}$ after cooling to room temperature. To this flask was added 2-(4-bromonaphthalen-1-yl)ethan-1-ol (802 mg, 3.19 mmol, 1.0 equiv) in THF (11 mL). The mixture was cooled to $-78{ }^{\circ} \mathrm{C}$ and then $n$-butyllithium (1.55 M in hexane, $4.12 \mathrm{~mL}, 2.0$ equiv) was added slowly. The mixture was stirred at $-78{ }^{\circ} \mathrm{C}$ for $45 \mathrm{~min}$. To this mixture was slowly added DMF $(371 \mu \mathrm{L}$, $4.79 \mathrm{mmol}, 1.5$ equiv). The mixture was further stirred at room temperature for $30 \mathrm{~min}$. The reaction was quenched with $\mathrm{NH}_{4} \mathrm{Cl}$ aq. and extracted three times with EtOAc. The combined organic layer was dried over $\mathrm{Na}_{2} \mathrm{SO}_{4}$, filtrated, and concentrated in vacuo. Purification by Isolera ${ }^{\circledR}$ (hexane/EtOAc $=$ 15:1 to 1:1) afforded 2-(4-bromonaphthalen-1-yl)ethan-1-ol (S1: $277 \mathrm{mg}, 43 \%$ yield) as a brown oil.

(Step 3) To a round-bottom flask containing S1 (160 mg, $0.800 \mathrm{mmol}, 1.0$ equiv) and dimethyl sulfate $(114 \mu \mathrm{L}, 1.20 \mathrm{mmol}, 1.5$ equiv) in THF $(3.0 \mathrm{~mL})$ was added sodium hydride $(60 \%$ oil dispersion; $64.0 \mathrm{mg}, 1.60 \mathrm{mmol}, 2.0$ equiv) at room temperature and then the mixture was stirred for $12 \mathrm{~h}$. The reaction was quenched with water at $0{ }^{\circ} \mathrm{C}$ and extracted three times with EtOAc. The combined organic layer was dried over $\mathrm{Na}_{2} \mathrm{SO}_{4}$, filtrated, and concentrated in vacuo. The residue was purified by Isolera ${ }^{\circledR}$ (hexane/EtOAc $=15: 1$ to $1: 1$ ) to afford 4-(2-methoxyethyl)-1-naphthaldehyde (123 mg, 72\% yield) as a yellow oil. 
(Step 4) To a solution of 4-(2-methoxyethyl)-1-naphthaldehyde (123 mg, $0.574 \mathrm{mmol}, 1.0$ equiv) in $\mathrm{MeCN}(5.8 \mathrm{~mL})$ were added potassium cyanide $(82.2 \mathrm{mg}, 1.26 \mathrm{mmol}, 2.2$ equiv) and diethyl chlorophosphate $(99.0 \mu \mathrm{L}, 0.688 \mathrm{mmol}, 1.2$ equiv). After stirring the mixture at room temperature for several hours with monitoring reaction progress with TLC, the reaction was quenched with $\mathrm{NaHCO}_{3}$ aq. and extracted three times with EtOAc. The combined organic layer was dried over $\mathrm{Na}_{2} \mathrm{SO}_{4}$, filtrated, and concentrated in vacuo. The residue was purified by Isolera ${ }^{\circledR}$ (hexane/EtOAc $=15: 1$ to $2: 3)$ to afford $\mathbf{1 H}(153 \mathrm{mg}, 71 \%$ yield $)$ as a colorless oil. ${ }^{1} \mathrm{H} \mathrm{NMR}\left(400 \mathrm{MHz}, \mathrm{CDCl}_{3}\right) \delta 8.26(\mathrm{~d}, J=$ $8.0 \mathrm{~Hz}, 1 \mathrm{H}), 8.16(\mathrm{~d}, J=8.0 \mathrm{~Hz}, 1 \mathrm{H}), 7.74(\mathrm{~d}, J=7.6 \mathrm{~Hz}, 1 \mathrm{H}), 7.68-7.60(\mathrm{~m}, 2 \mathrm{H}), 7.42(\mathrm{~d}, J=7.6 \mathrm{~Hz}$, $1 \mathrm{H}), 6.63\left(\mathrm{~d}, J_{\mathrm{H}-\mathrm{P}}=8.8 \mathrm{~Hz}, 1 \mathrm{H}\right), 4.32-4.17(\mathrm{~m}, 2 \mathrm{H}), 4.02-3.86(\mathrm{~m}, 2 \mathrm{H}), 3.74(\mathrm{t}, J=7.2 \mathrm{~Hz}, 2 \mathrm{H}), 3.42-$ $3.38(\mathrm{~m}, 5 \mathrm{H}), 1.45-1.35(\mathrm{~m}, 3 \mathrm{H}), 1.15-1.05(\mathrm{~m}, 3 \mathrm{H}) ;{ }^{13} \mathrm{C} \mathrm{NMR}\left(101 \mathrm{MHz}, \mathrm{CDCl}_{3}\right) \delta 139.2,132.6$, $130.2,127.1,126.6,126.4\left(\mathrm{~d}, J_{\mathrm{C}-\mathrm{P}}=5.7 \mathrm{~Hz}\right), 125.9,124.7,123.6,116.2\left(\mathrm{~d}, J_{\mathrm{C}-\mathrm{P}}=4.8 \mathrm{~Hz}\right), 72.4,65.3$ $\left(\mathrm{d}, J_{\mathrm{C}-\mathrm{P}}=5.7 \mathrm{~Hz}\right), 64.9\left(\mathrm{~d}, J_{\mathrm{C}-\mathrm{P}}=5.8 \mathrm{~Hz}\right), 64.6\left(\mathrm{~d}, J_{\mathrm{C}-\mathrm{P}}=5.7 \mathrm{~Hz}\right), 58.7,33.3,15.9\left(\mathrm{~d}, J_{\mathrm{C}-\mathrm{P}}=6.7 \mathrm{~Hz}\right)$, $15.7\left(\mathrm{~d}, J_{\mathrm{C}-\mathrm{P}}=7.7 \mathrm{~Hz}\right)$ (one peak is missing due to overlapping); ${ }^{31} \mathrm{P} \mathrm{NMR}\left(162 \mathrm{MHz}, \mathrm{CDCl}_{3}\right) \delta-3.73$; HRMS (DART) $m / z$ calcd for $\mathrm{C}_{19} \mathrm{H}_{28} \mathrm{~N}_{2} \mathrm{O}_{5} \mathrm{P}\left[\mathrm{M}+\mathrm{NH}_{4}\right]^{+}: 395.1730$ found 395.1721 .

\section{Synthesis of 2-(4-(Cyano((diethoxyphosphoryl)oxy)methyl)naphthalen-1-yl)ethyl Acetate (1I)}

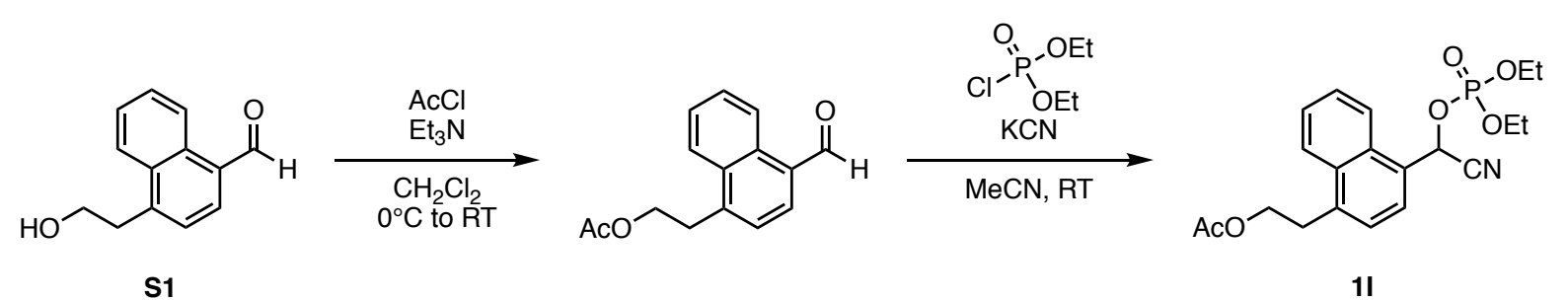

To a round-bottom flask containing $\mathbf{S} 1(277 \mathrm{mg}, 1.38 \mathrm{mmol}, 1.0$ equiv) and triethylamine $(289 \mu \mathrm{L}$, 2.08 mmol, 1.5 equiv) in $\mathrm{CH}_{2} \mathrm{Cl}_{2}(5.0 \mathrm{~mL})$ was added acetyl chloride (119 $\mu \mathrm{L}, 1.66 \mathrm{mmol}, 1.2$ equiv) at $0{ }^{\circ} \mathrm{C}$ and then the mixture was stirred at room temperature for $12 \mathrm{~h}$. The reaction was quenched with water at $0{ }^{\circ} \mathrm{C}$ and extracted three times with $\mathrm{CH}_{2} \mathrm{Cl}_{2}$. The combined organic layer was dried over $\mathrm{Na}_{2} \mathrm{SO}_{4}$, filtrated, and concentrated in vacuo. The residue was purified by Isolera ${ }^{\circledR}$ (hexane/EtOAc $=$ 15:1 to 1:1) to afford 2-(4-formylnaphthalen-1-yl)ethyl acetate (198 $\mathrm{mg}, 60 \%$ yield) as a yellow oil.

To a solution of 2-(4-formylnaphthalen-1-yl)ethyl acetate (198 mg, $0.818 \mathrm{mmol}, 1.0$ equiv) in $\mathrm{MeCN}(8.2 \mathrm{~mL})$ were added potassium cyanide $(117 \mathrm{mg}, 1.80 \mathrm{mmol}, 2.2$ equiv) and diethyl chlorophosphate (141 $\mu \mathrm{L}, 0.981 \mathrm{mmol}, 1.2$ equiv). After stirring the mixture at room temperature for several hours with monitoring reaction progress with TLC, the reaction was quenched with $\mathrm{NaHCO}_{3}$ aq. and extracted three times with EtOAc. The combined organic layer was dried over $\mathrm{Na}_{2} \mathrm{SO}_{4}$, filtrated, and concentrated in vacuo. The residue was purified by Isolera ${ }^{\circledR}$ (hexane/EtOAc $=15: 1$ to $2: 3)$ to afford $\mathbf{1 I}\left(257 \mathrm{mg}, 78 \%\right.$ yield) as a colorless oil. ${ }^{1} \mathrm{H}$ NMR $\left(400 \mathrm{MHz}, \mathrm{CDCl}_{3}\right) \delta 8.27$ (dd, $J=$ $8.0,2.0 \mathrm{~Hz}, 1 \mathrm{H}), 8.19(\mathrm{dd}, J=8.0,2.0 \mathrm{~Hz}, 1 \mathrm{H}), 7.75(\mathrm{~d}, J=7.2 \mathrm{~Hz}, 1 \mathrm{H}), 7.70-7.62(\mathrm{~m}, 2 \mathrm{H}), 7.42(\mathrm{~d}, J$ $=7.2 \mathrm{~Hz}, 1 \mathrm{H}), 6.64\left(\mathrm{~d}, J_{\mathrm{H}-\mathrm{P}}=8.8 \mathrm{~Hz}, 1 \mathrm{H}\right), 4.42(\mathrm{t}, J=7.2 \mathrm{~Hz}, 2 \mathrm{H}), 4.33-4.14(\mathrm{~m}, 2 \mathrm{H}), 4.03-3.86(\mathrm{~m}$, $2 \mathrm{H}), 3.45(\mathrm{t}, J=7.2 \mathrm{~Hz}, 2 \mathrm{H}), 2.05(\mathrm{~s}, 3 \mathrm{H}), 1.45-1.35(\mathrm{~m}, 3 \mathrm{H}), 1.18-1.08(\mathrm{~m}, 3 \mathrm{H}) ;{ }^{13} \mathrm{C}$ NMR $(101$ 
$\left.\mathrm{MHz}, \mathrm{CDCl}_{3}\right) \delta 171.0,138.0,132.5,130.2,127.4,127.1,126.92,126.89\left(\mathrm{~d}, J_{\mathrm{C}-\mathrm{P}}=6.7 \mathrm{~Hz}\right), 126.1$, 124.6, 123.6, $116.2\left(\mathrm{~d}, J_{\mathrm{C}-\mathrm{P}}=4.8 \mathrm{~Hz}\right), 65.3\left(\mathrm{~d}, J_{\mathrm{C}-\mathrm{P}}=4.8 \mathrm{~Hz}\right), 64.9\left(\mathrm{~d}, J_{\mathrm{C}-\mathrm{P}}=5.9 \mathrm{~Hz}\right), 64.7\left(\mathrm{~d}, J_{\mathrm{C}-\mathrm{P}}=\right.$ $5.8 \mathrm{~Hz}), 64.0,32.3,20.9,16.0\left(\mathrm{~d}, J_{\mathrm{C}-\mathrm{P}}=6.7 \mathrm{~Hz}\right), 15.7\left(\mathrm{~d}, J_{\mathrm{C}-\mathrm{P}}=7.6 \mathrm{~Hz}\right) ;{ }^{31} \mathrm{P}$ NMR $\left(162 \mathrm{MHz}, \mathrm{CDCl}_{3}\right)$ $\delta-4.35$; HRMS (DART) $\mathrm{m} / z$ calcd for $\mathrm{C}_{20} \mathrm{H}_{28} \mathrm{~N}_{2} \mathrm{O}_{6} \mathrm{P}\left[\mathrm{M}+\mathrm{NH}_{4}\right]^{+}: 423.1679$ found 423.1675.

\section{Synthesis of (4-(2-((tert-Butyldimethylsilyl)oxy)ethyl)naphthalen-1-yl)(cyano)methyl Diethyl}

\section{Phosphate (1J)}

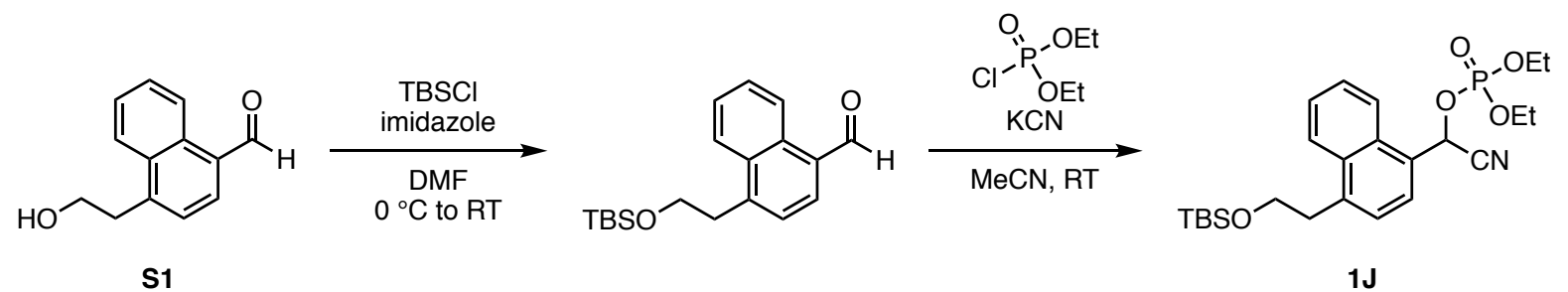

To a round-bottom flask containing $\mathbf{S 1}(195 \mathrm{mg}, 0.971 \mathrm{mmol}, 1.0$ equiv) and imidazole $(159 \mathrm{mg}$, $2.33 \mathrm{mmol}, 2.4$ equiv) in DMF (4.9 mL) was added TBSCl (293 mg, $1.94 \mathrm{mmol}, 2.0$ equiv) at $0{ }^{\circ} \mathrm{C}$ and then the mixture was stirred at room temperature for $3 \mathrm{~h}$. The reaction was quenched with brine at $0{ }^{\circ} \mathrm{C}$ and extracted three times with $\mathrm{Et}_{2} \mathrm{O}$. The combined organic layer was dried over $\mathrm{MgSO}_{4}$, filtrated, and concentrated in vacuo. The residue was purified by Isolera ${ }^{\circledR}$ (hexane to hexane/EtOAc $=10: 1$ ) to afford 4-(2-((tert-butyldimethylsilyl)oxy)ethyl)-1-naphthaldehyde (222 mg, 73\% yield) as a yellow oil.

To a solution of 4-(2-((tert-butyldimethylsilyl)oxy)ethyl)-1-naphthaldehyde (222 mg, $0.707 \mathrm{mmol}$, 1.0 equiv) in $\mathrm{MeCN}$ (7.1 mL) were added potassium cyanide (101 mg, $1.56 \mathrm{mmol}, 2.2$ equiv) and diethyl chlorophosphate $(122 \mu \mathrm{L}, 0.849 \mathrm{mmol}, 1.2$ equiv). After stirring the mixture at room temperature for several hours with monitoring reaction progress with TLC, the reaction was quenched with $\mathrm{NaHCO}_{3}$ aq. and extracted three times with EtOAc. The combined organic layer was dried over $\mathrm{Na}_{2} \mathrm{SO}_{4}$, filtrated, and concentrated in vacuo. The residue was purified by Isolera ${ }^{\circledR}$ (hexane/EtOAc $=$ 15:1 to $2: 1)$ to afford $\mathbf{1 J}\left(253 \mathrm{mg}, 75 \%\right.$ yield) as a yellow oil. ${ }^{1} \mathrm{H} \mathrm{NMR}\left(400 \mathrm{MHz}, \mathrm{CDCl}_{3}\right) \delta 8.25(\mathrm{~d}, J$ $=8.0 \mathrm{~Hz}, 1 \mathrm{H}), 8.17(\mathrm{~d}, J=8.0 \mathrm{~Hz}, 1 \mathrm{H}), 7.73(\mathrm{~d}, J=7.2 \mathrm{~Hz}, 1 \mathrm{H}), 7.68-7.58(\mathrm{~m}, 2 \mathrm{H}), 7.41(\mathrm{~d}, J=7.2$ $\mathrm{Hz}, 1 \mathrm{H}), 6.64\left(\mathrm{~d}, J_{\mathrm{H}-\mathrm{P}}=9.2 \mathrm{~Hz}, 1 \mathrm{H}\right), 4.33-4.17(\mathrm{~m}, 2 \mathrm{H}), 4.02-3.85(\mathrm{~m}, 4 \mathrm{H}), 3.34(\mathrm{t}, J=7.2 \mathrm{~Hz}, 2 \mathrm{H})$, $1.45-1.35(\mathrm{~m}, 3 \mathrm{H}), 1.18-1.08(\mathrm{~m}, 3 \mathrm{H}), 0.84(\mathrm{~s}, 9 \mathrm{H}),-0.06(\mathrm{~s}, 6 \mathrm{H}) ;{ }^{13} \mathrm{C}$ NMR $\left(101 \mathrm{MHz}, \mathrm{CDCl}_{3}\right) \delta$ 139.6, 132.7, 130.1, 127.04, 126.97, 126.4, 126.24, 126.22 (d, $\left.J_{\mathrm{C}-\mathrm{P}}=4.8 \mathrm{~Hz}\right), 124.9,123.4,116.2(\mathrm{~d}$, $\left.J_{\mathrm{C}-\mathrm{P}}=4.8 \mathrm{~Hz}\right), 65.3\left(\mathrm{~d}, J_{\mathrm{C}-\mathrm{P}}=4.8 \mathrm{~Hz}\right), 64.8\left(\mathrm{~d}, J_{\mathrm{C}-\mathrm{P}}=6.7 \mathrm{~Hz}\right), 64.6\left(\mathrm{~d}, J_{\mathrm{C}-\mathrm{P}}=5.8 \mathrm{~Hz}\right), 63.4,36.6,25.7$, $18.1,15.9\left(\mathrm{~d}, J_{\mathrm{C}-\mathrm{P}}=7.7 \mathrm{~Hz}\right), 15.6\left(\mathrm{~d}, J_{\mathrm{C}-\mathrm{P}}=6.7 \mathrm{~Hz}\right),-5.6 ;{ }^{31} \mathrm{P} \mathrm{NMR}\left(162 \mathrm{MHz}, \mathrm{CDCl}_{3}\right) \delta-4.35$; HRMS (ESI) $m / z$ calcd for $\mathrm{C}_{24} \mathrm{H}_{36} \mathrm{NNaO}_{5} \mathrm{PSi}[\mathrm{M}+\mathrm{Na}]^{+}: 500.1993$ found 500.1991 . 


\section{Pd-Catalyzed Dearomative Allylation of Cyanophosphates}

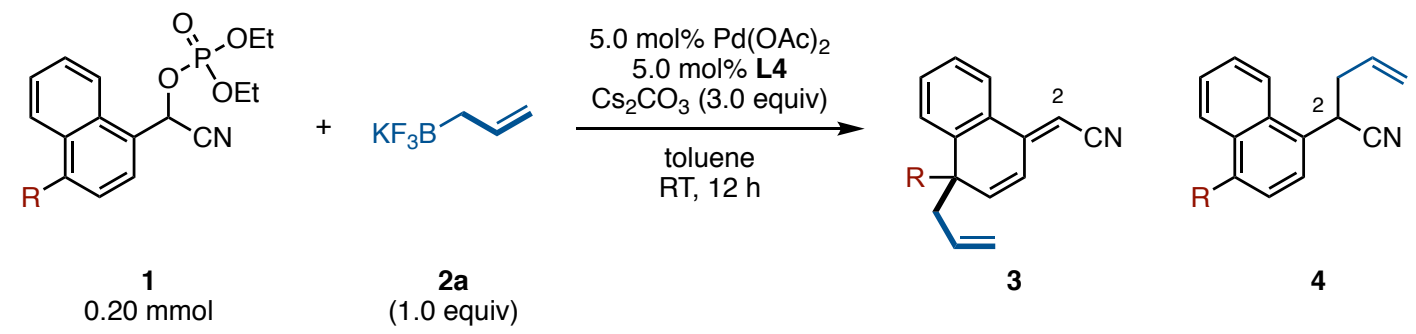

\section{General Procedure}

To an 8-mL glass tube equipped with a screw cap containing a magnetic stirring bar and cesium carbonate (196 mg, $0.600 \mathrm{mmol}, 3.0$ equiv) was dried with a heat-gun in vacuo and filled with $\mathrm{N}_{2}$ after cooling to room temperature. To this tube were added $\mathrm{Pd}(\mathrm{OAc})_{2}(2.25 \mathrm{mg}, 10.0 \mu \mathrm{mol}, 5.0 \mathrm{~mol} \%)$, tris(3,5-dimethoxyphenyl)phosphine $\quad(\mathbf{L 4}: \quad 4.42 \quad \mathrm{mg}, \quad 10.0 \quad \mu \mathrm{mol}, \quad 5.0 \quad \mathrm{~mol} \%), \quad$ potassium allyltrifluoroborate (2a: $29.6 \mathrm{mg}, 0.200 \mathrm{mmol}, 1.0$ equiv). The tube was placed under vacuum and refilled $\mathrm{N}_{2}$ gas three times. To this tube was added a solution of cyanophosphates $\mathbf{1}(0.200 \mathrm{mmol}, 1.0$ equiv) in toluene $(1.0 \mathrm{~mL})$. The tube was sealed with a screw cap. After stirring the mixture at room temperature for $12 \mathrm{~h}$, the mixture was passed through a short alumina pad with hexane/EtOAc $=3: 1$ as an eluent. The filtrate was concentrated in vacuo. The yield of $\mathbf{3}$ was determined by ${ }^{1} \mathrm{H}$ NMR analysis using $\mathrm{CH}_{2} \mathrm{Br}_{2}$ as an internal standard $\left({ }^{1} \mathrm{H}\right.$ NMR signal of compound 3 at the $\mathrm{C} 2$ position was generally used to determine the yield). The ratio of $\mathbf{3 : 4}$ was determined by ${ }^{1} \mathrm{H}$ NMR analysis ( ${ }^{1} \mathrm{H}$ NMR signal of compound 4 at the $\mathrm{C} 2$ position (ca. $\delta 4.60 \mathrm{ppm}$, dd, $1 \mathrm{H}$ ) was used). The residue was purified by Isolera $^{\circledR}$ with a Biotage SNAP Ultra column or a basic alumina column cartridge to afford the corresponding dearomatized product 3 .

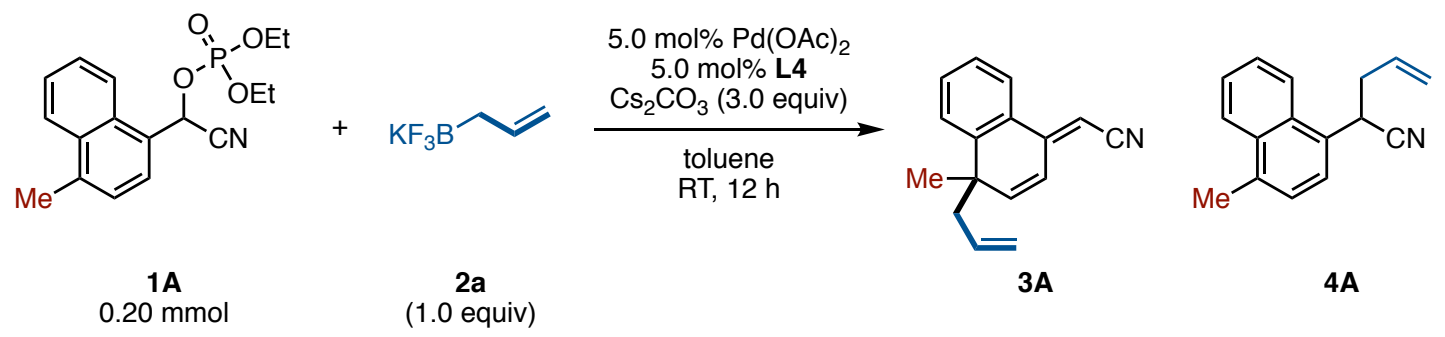

\section{(E)-2-(4-Allyl-4-methylnaphthalen-1(4H)-ylidene)acetonitrile (3A)}

Crude ${ }^{1} \mathrm{H}$ NMR showed $\mathbf{3 A}$ and $\mathbf{4 A}$ was generated in $70 \%$ yield $(\mathbf{3 A}: \mathbf{4 A}=97: 3)$. Purification by Isolera $^{\circledR}$ with a Biotage SNAP Ultra column (hexane to hexane/EtOAc $\left.=10: 1\right)$ afforded 3A $(28.2 \mathrm{mg}$, $64 \%$ yield) as a colorless oil. ${ }^{1} \mathrm{H}$ NMR $\left(400 \mathrm{MHz}, \mathrm{CDCl}_{3}\right) \delta 7.68(\mathrm{~d}, J=8.0 \mathrm{~Hz}, 1 \mathrm{H}), 7.52-7.42$ (m, 2H), 7.32-7.27 (m, 1H), $7.00(\mathrm{~d}, J=10.8 \mathrm{~Hz}, 1 \mathrm{H}), 6.22(\mathrm{dd}, J=10.8,1.2 \mathrm{~Hz}, 1 \mathrm{H}), 5.72(\mathrm{~d}, J=1.2 \mathrm{~Hz}$, 1H), 5.41-5.28 (m, 1H), 4.94-4.81 (m, 2H), 2.62 (dd, $J=14.0,7.2 \mathrm{~Hz}, 1 \mathrm{H}), 2.48$ (dd, $J=14.0,7.2 \mathrm{~Hz}$, 1H), $1.44(\mathrm{~s}, 3 \mathrm{H}) ;{ }^{13} \mathrm{C}$ NMR $\left(101 \mathrm{MHz}, \mathrm{CDCl}_{3}\right) \delta 149.1,144.8,143.6,133.3,130.6,128.7,126.9$, 
126.7, 123.2, 123.0, 118.2, 118.0, 88.2, 48.0, 41.6, 29.2; HRMS (DART) $m / z$ calcd for $\mathrm{C}_{16} \mathrm{H}_{19} \mathrm{~N}_{2}[\mathrm{M}+$ $\left.\mathrm{NH}_{4}\right]^{+}: 239.1543$ found 239.1538 .

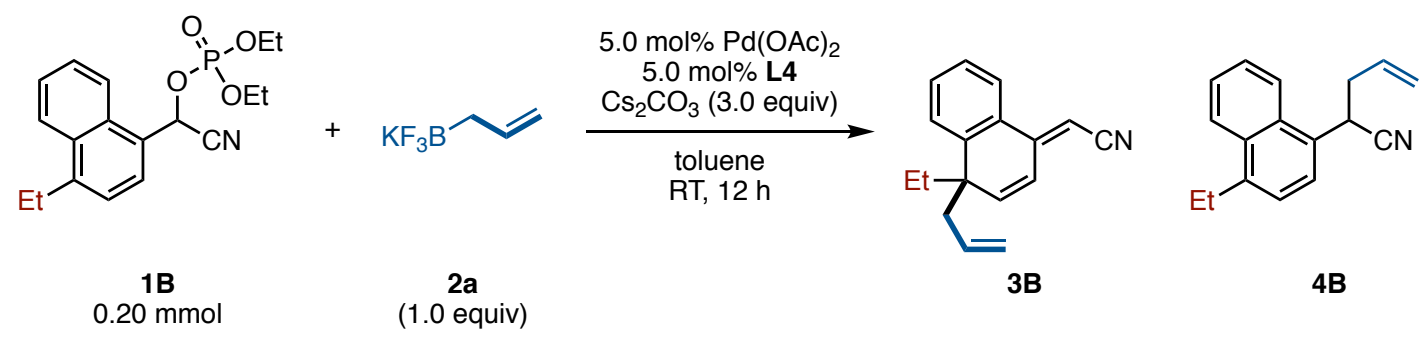

\section{(E)-2-(4-Allyl-4-ethylnaphthalen-1(4H)-ylidene)acetonitrile (3B)}

Crude ${ }^{1} \mathrm{H}$ NMR showed 3B and 4B was generated in $76 \%$ yield $(3 \mathrm{~B}: 4 \mathrm{~B}=98: 2)$. Purification by Isolera $^{\circledR}$ with a Biotage SNAP Ultra column (hexane to hexane/EtOAc $\left.=10: 1\right)$ afforded 3B $(32.8 \mathrm{mg}$, $70 \%$ yield) as a colorless oil. ${ }^{1} \mathrm{H}$ NMR $\left(400 \mathrm{MHz}, \mathrm{CDCl}_{3}\right) \delta 7.69(\mathrm{~d}, J=8.8 \mathrm{~Hz}, 1 \mathrm{H}), 7.49-7.40$ (m, $2 \mathrm{H}), 7.32-7.26(\mathrm{~m}, 1 \mathrm{H}), 7.11(\mathrm{~d}, J=10.0 \mathrm{~Hz}, 1 \mathrm{H}), 6.11(\mathrm{dd}, J=10.0,1.2 \mathrm{~Hz}, 1 \mathrm{H}), 5.72(\mathrm{~d}, J=1.2 \mathrm{~Hz}$, $1 \mathrm{H}), 5.38-5.26(\mathrm{~m}, 1 \mathrm{H}), 4.90-4.81(\mathrm{~m}, 2 \mathrm{H}), 2.64(\mathrm{dd}, J=14.0,7.2 \mathrm{~Hz}, 1 \mathrm{H}), 2.46(\mathrm{dd}, J=14.0,7.2 \mathrm{~Hz}$, $1 \mathrm{H}), 2.05-1.94(\mathrm{~m}, 1 \mathrm{H}), 1.82-1.71(\mathrm{~m}, 1 \mathrm{H}), 0.51(\mathrm{t}, J=7.6 \mathrm{~Hz}, 3 \mathrm{H}) ;{ }^{13} \mathrm{C} \mathrm{NMR}\left(101 \mathrm{MHz}, \mathrm{CDCl}_{3}\right) \delta$ 149.3, 143.8, 141.8, 133.3, 130.7, 130.1, 126.6, 125.0, 123.1, 118.3, 117.8, 88.2, 47.5, 46.6, 35.3, 8.9 (one peak is missing due to overlapping); HRMS (DART) $m / z$ calcd for $\mathrm{C}_{17} \mathrm{H}_{21} \mathrm{~N}_{2}\left[\mathrm{M}+\mathrm{NH}_{4}\right]^{+}$: 253.1699 found 253.1694 .
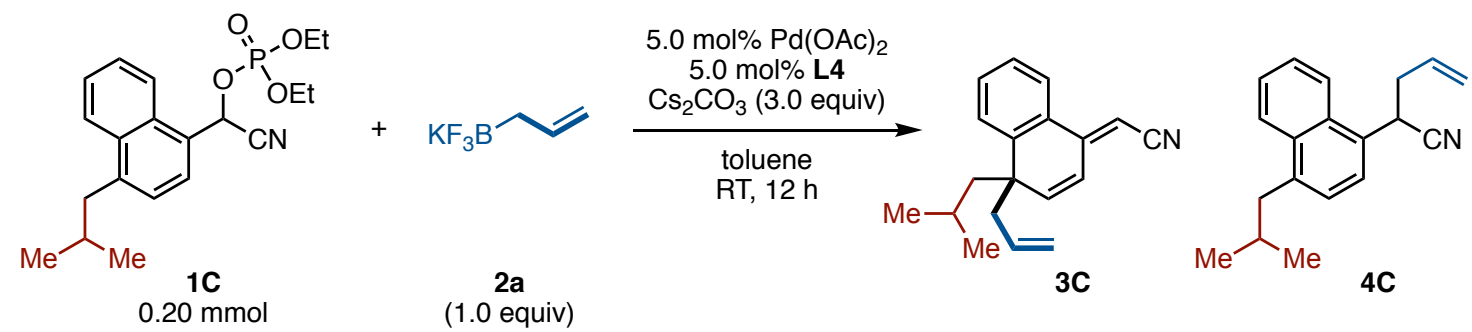

\section{(E)-2-(4-Allyl-4-isobutylnaphthalen-1(4H)-ylidene)acetonitrile (3C)}

Crude ${ }^{1} \mathrm{H}$ NMR showed $\mathbf{3 C}$ and $\mathbf{4 C}$ was generated in $71 \%$ yield $(\mathbf{3 C}: \mathbf{4 C}=92: 8)$. Purification by Isolera $^{\circledR}$ with a Biotage SNAP Ultra column (hexane to hexane/EtOAc $\left.=10: 1\right)$ afforded 3C $(30.0 \mathrm{mg}$, $57 \%$ yield) as a colorless oil. ${ }^{1} \mathrm{H}$ NMR $\left(400 \mathrm{MHz} \mathrm{CDCl}_{3}\right) \delta 7.69(\mathrm{~d}, J=8.0 \mathrm{~Hz}, 1 \mathrm{H}), 7.48-7.42$ (m, 2H), 7.29 (dd, $J=8.0,4.0 \mathrm{~Hz}, 1 \mathrm{H}), 7.08$ (d, $J=10.4 \mathrm{~Hz}, 1 \mathrm{H}), 6.19$ (dd, $J=10.4,1.2 \mathrm{~Hz}, 1 \mathrm{H}), 5.72(\mathrm{~d}$, $J=1.2 \mathrm{~Hz}, 1 \mathrm{H}), 5.33-5.20(\mathrm{~m}, 1 \mathrm{H}), 4.87-4.78(\mathrm{~m}, 2 \mathrm{H}), 2.57$ (dd, $J=13.6,7.2 \mathrm{~Hz}, 1 \mathrm{H}), 2.39$ (dd, $J=$ 13.6, 7.2 Hz, 1H), 1.98 (dd, $J=14.4,6.0 \mathrm{~Hz}, 1 \mathrm{H}), 1.69$ (dd, $J=14.4,6.0 \mathrm{~Hz}, 1 \mathrm{H}), 1.35-1.22(\mathrm{~m}, 1 \mathrm{H})$, $0.77(\mathrm{~d}, J=6.8 \mathrm{~Hz}, 3 \mathrm{H}), 0.46(\mathrm{~d}, J=6.8 \mathrm{~Hz}, 3 \mathrm{H}) ;{ }^{13} \mathrm{C} \mathrm{NMR}\left(101 \mathrm{MHz}, \mathrm{CDCl}_{3}\right) \delta 149.3,144.6,142.4$, 132.9, 130.4, 129.7, 127.2, 126.6, 124.0, 123.1, 118.4, 118.0, 88.0, 51.1, 49.0, 46.1, 25.4, 24.3, 24.0; HRMS (DART) $m / z$ calcd for $\mathrm{C}_{19} \mathrm{H}_{25} \mathrm{~N}_{2}\left[\mathrm{M}+\mathrm{NH}_{4}\right]^{+}: 281.2012$ found 281.2015. 


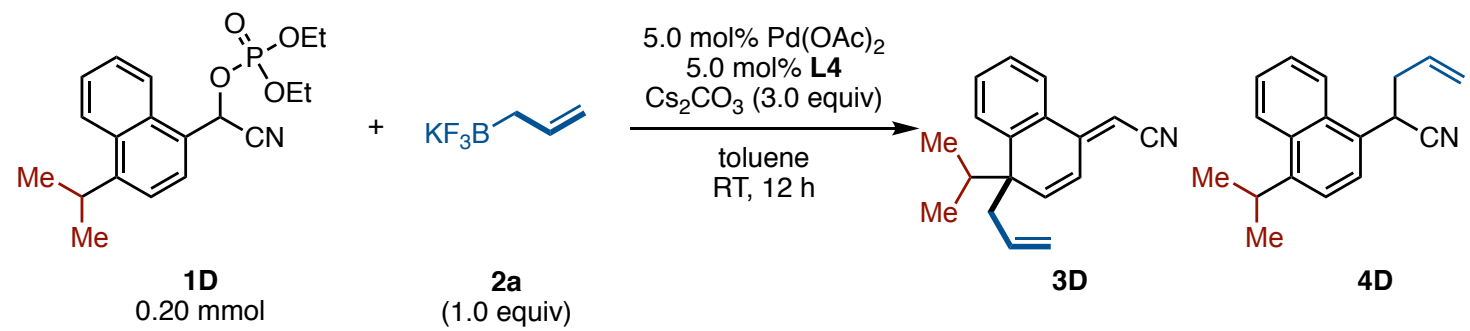

\section{(E)-2-(4-Allyl-4-isopropylnaphthalen-1(4H)-ylidene)acetonitrile (3D)}

Crude ${ }^{1} \mathrm{H}$ NMR showed 3D and 4D was generated in 61\% yield (3D:4D $\left.=95: 5\right)$. Purification by Isolera $^{\circledR}$ with a basic alumina column cartridge (hexane to hexane/EtOAc $\left.=10: 1\right)$ afforded 3D (26.0 $\mathrm{mg}, 52 \%$ yield) as a colorless oil. ${ }^{1} \mathrm{H}$ NMR $\left(400 \mathrm{MHz}, \mathrm{CDCl}_{3}\right) \delta 7.68(\mathrm{~d}, J=8.0 \mathrm{~Hz}, 1 \mathrm{H}), 7.48-7.40$ (m, 2H), 7.31-7.26 (m, 1H), 7.15 (d, $J=10.4 \mathrm{~Hz}, 1 \mathrm{H}), 6.24$ (d, $J=10.4 \mathrm{~Hz}, 1 \mathrm{H}), 5.71(\mathrm{~s}, 1 \mathrm{H}), 5.24-$ $5.11(\mathrm{~m}, 1 \mathrm{H}), 4.89-4.74(\mathrm{~m}, 2 \mathrm{H}), 2.75-2.61(\mathrm{~m}, 2 \mathrm{H}), 2.22-2.11(\mathrm{~m}, 1 \mathrm{H}), 1.05(\mathrm{~d}, J=7.2 \mathrm{~Hz}, 3 \mathrm{H})$, $0.51(\mathrm{~d}, J=7.2 \mathrm{~Hz}, 3 \mathrm{H}) ;{ }^{13} \mathrm{C}$ NMR $\left(101 \mathrm{MHz}, \mathrm{CDCl}_{3}\right) \delta 149.3,142.7,140.8,133.8,130.5,130.2$, 126.8, 126.5, 125.8, 123.0, 118.3, 117.4, 88.1, 48.9, 43.9, 39.6, 18.3, 17.4; HRMS (DART) $\mathrm{m} / z$ calcd for $\mathrm{C}_{18} \mathrm{H}_{23} \mathrm{~N}_{2}\left[\mathrm{M}+\mathrm{NH}_{4}\right]^{+}: 267.1856$ found 267.1852.
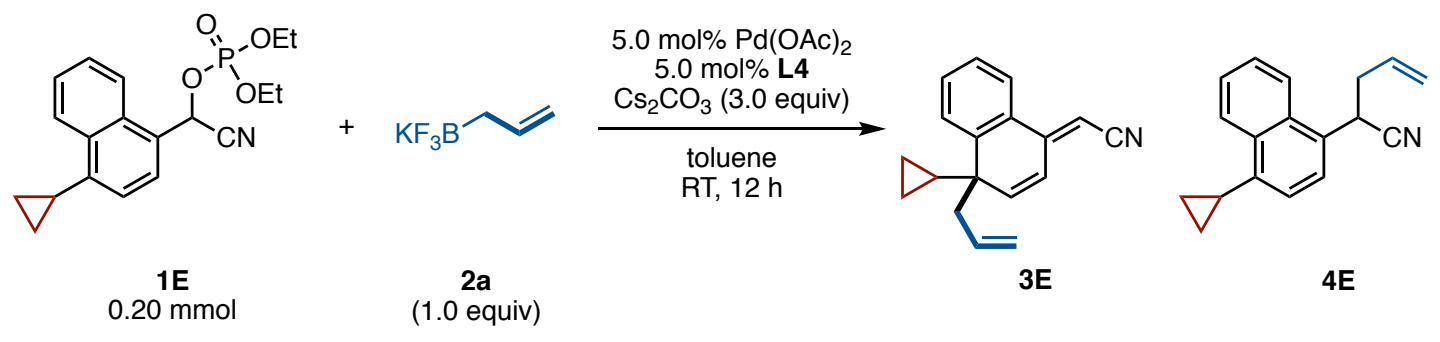

\section{(E)-2-(4-Allyl-4-cyclopropylnaphthalen-1(4H)-ylidene)acetonitrile (3E)}

Crude ${ }^{1} \mathrm{H}$ NMR showed $\mathbf{3 E}$ and $\mathbf{4 E}$ was generated in $66 \%$ yield $(\mathbf{3 E}: \mathbf{4 E}=91: 9)$. Purification by Isolera $^{\circledR}$ with a Biotage SNAP Ultra column (hexane to hexane/EtOAc $\left.=10: 1\right)$ afforded 3E $(24.5 \mathrm{mg}$, $50 \%$ yield) as a colorless oil. ${ }^{1} \mathrm{H}$ NMR $\left(400 \mathrm{MHz}, \mathrm{CDCl}_{3}\right) \delta 7.67(\mathrm{~d}, J=8.0 \mathrm{~Hz}, 1 \mathrm{H}), 7.57(\mathrm{~d}, J=8.0$ Hz, 1H), 7.50-7.43 (m, 1H), 7.33-7.27 (m, 1H), 7.04 (d, $J=10.4 \mathrm{~Hz}, 1 \mathrm{H}), 6.05$ (dd, $J=10.4,1.6 \mathrm{~Hz}$, $1 \mathrm{H}), 5.72(\mathrm{~d}, J=1.6 \mathrm{~Hz}, 1 \mathrm{H}), 5.40-5.28(\mathrm{~m}, 1 \mathrm{H}), 4.95-4.80(\mathrm{~m}, 2 \mathrm{H}), 2.75(\mathrm{dd}, J=14.0,7.2 \mathrm{~Hz}, 1 \mathrm{H})$, $2.51(\mathrm{dd}, J=14.0,7.2 \mathrm{~Hz}, 1 \mathrm{H}), 1.24-1.15(\mathrm{~m}, 1 \mathrm{H}), 0.53-0.45$ (m, 1H), 0.45-0.37 (m, 1H), 0.33-0.24 $(\mathrm{m}, 1 \mathrm{H}), 0.11-0.03(\mathrm{~m}, 1 \mathrm{H}) ;{ }^{13} \mathrm{C}$ NMR $\left(101 \mathrm{MHz}, \mathrm{CDCl}_{3}\right) \delta 149.0,143.1,141.2,133.3,130.5,129.0$, 127.3, 126.7, 125.0, 123.1, 118.2, 117.8, 88.6, 44.8, 44.1, 23.2, 1.9, 1.0; HRMS (DART) $\mathrm{m} / z$ calcd for $\mathrm{C}_{18} \mathrm{H}_{21} \mathrm{~N}_{2}\left[\mathrm{M}+\mathrm{NH}_{4}\right]^{+}: 265.1699$ found 265.1696.
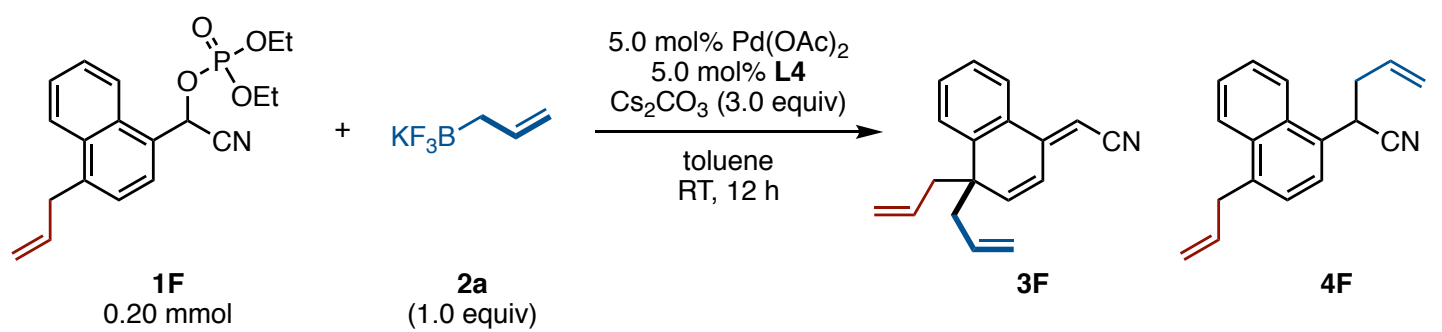


\section{(E)-2-(4,4-Diallylnaphthalen-1(4H)-ylidene)acetonitrile (3F)}

Crude ${ }^{1} \mathrm{H}$ NMR showed $\mathbf{3 F}$ and $\mathbf{4 F}$ was generated in $66 \%$ yield $(\mathbf{3 F}: \mathbf{4 F}=93: 7)$. Purification by Isolera $^{\circledR}$ with a basic alumina column cartridge (hexane to hexane/EtOAc $\left.=10: 1\right)$ afforded $\mathbf{3 F}(24.5 \mathrm{mg}$, $50 \%$ yield $)$ as a white solid. mp $64-65{ }^{\circ} \mathrm{C}:{ }^{1} \mathrm{H}$ NMR $\left(400 \mathrm{MHz}, \mathrm{CDCl}_{3}\right) \delta 7.68(\mathrm{~d}, J=8.0 \mathrm{~Hz}, 1 \mathrm{H})$, 7.50-7.44 (m, 2H), 7.33-7.25 (m, 1H), 7.08 (d, $J=10.0 \mathrm{~Hz}, 1 \mathrm{H}), 6.18$ (dd, $J=10.0,1.6 \mathrm{~Hz}, 1 \mathrm{H}), 5.71$ (d, $J=1.6 \mathrm{~Hz}, 1 \mathrm{H}), 5.39-5.26$ (m, 2H), 4.93-4.83 (m, 4H), 2.67 (dd, $J=14.0,7.2 \mathrm{~Hz}, 2 \mathrm{H}), 2.49$ (dd, $J$ $=14.0,7.2 \mathrm{~Hz}, 2 \mathrm{H}) ;{ }^{13} \mathrm{C} \mathrm{NMR}\left(101 \mathrm{MHz}, \mathrm{CDCl}_{3}\right) \delta 149.1,143.2,141.6,132.9,130.6,129.8,126.9$, 126.8, 124.6, 123.2, 118.22, 118.16, 88.4, 46.8, 45.8; HRMS (ESI) $m / z$ calcd for $\mathrm{C}_{18} \mathrm{H}_{21} \mathrm{~N}_{2}[\mathrm{M}+$ $\left.\mathrm{NH}_{4}\right]^{+}: 265.1699$ found 265.1696 .

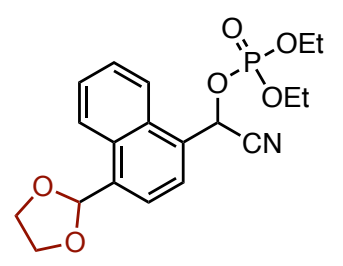

$0.20 \mathrm{mmo}$

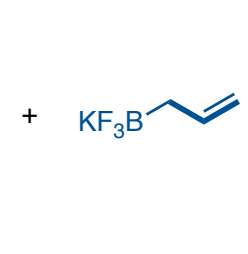

2a
$(1.0$ equiv $)$

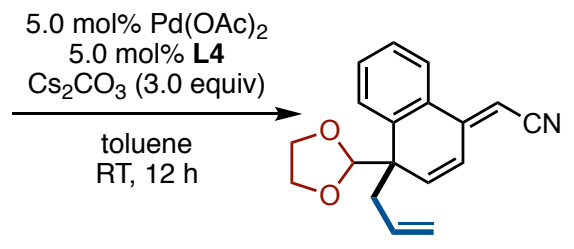

$3 G$<smiles>C=CCC(C#N)c1ccc(C2OCCO2)c2ccccc12</smiles>

4G

\section{(E)-2-(4-Allyl-4-(1,3-dioxolan-2-yl)naphthalen-1(4H)-ylidene)acetonitrile (3G)}

Crude ${ }^{1} \mathrm{H}$ NMR showed $\mathbf{3 G}$ and $\mathbf{4 G}$ was generated in $\mathbf{7 5 \%}$ yield $(\mathbf{3 G}: \mathbf{4 G}=93: 7)$. Purification by Isolera ${ }^{\circledR}$ with a Biotage SNAP Ultra column (hexane to hexane/EtOAc $\left.=10: 1\right)$ afforded 3G $(34.2 \mathrm{mg}$, $61 \%$ yield) as a white solid. mp 66-67 ${ }^{\circ} \mathrm{C}:{ }^{1} \mathrm{H}$ NMR $\left(400 \mathrm{MHz}, \mathrm{CDCl}_{3}\right) \delta 7.72(\mathrm{dd}, J=8.4,0.8 \mathrm{~Hz}$, 1H), $7.60(\mathrm{dd}, J=8.4,0.8 \mathrm{~Hz}, 1 \mathrm{H}), 7.50-7.44(\mathrm{~m}, 1 \mathrm{H}), 7.37-7.31(\mathrm{~m}, 1 \mathrm{H}), 7.17(\mathrm{~d}, J=10.4 \mathrm{~Hz}, 1 \mathrm{H})$, $6.33(\mathrm{dd}, J=10.4,1.6 \mathrm{~Hz}, 1 \mathrm{H}), 5.76(\mathrm{~d}, J=1.6 \mathrm{~Hz}, 1 \mathrm{H}), 5.34-5.22(\mathrm{~m}, 1 \mathrm{H}), 5.04(\mathrm{~s}, 1 \mathrm{H}), 4.98-4.82$ (m, 2H), 3.88-2.77 (m, 4H), $2.89(\mathrm{dd}, J=14.0,6.8 \mathrm{~Hz}, 1 \mathrm{H}), 2.48(\mathrm{dd}, J=14.0,6.8 \mathrm{~Hz}, 1 \mathrm{H}) ;{ }^{13} \mathrm{C} \mathrm{NMR}$ $\left(101 \mathrm{MHz}, \mathrm{CDCl}_{3}\right) \delta 148.9,138.8,138.0,132.5,130.3,130.2,127.7,127.3,126.3,123.3,118.3,118.1$, 108.4, 89.1, 65.60, 65.57, 49.7, 40.3; HRMS (DART) $m / z$ calcd for $\mathrm{C}_{18} \mathrm{H}_{21} \mathrm{~N}_{2} \mathrm{O}_{2}\left[\mathrm{M}+\mathrm{NH}_{4}\right]^{+}: 297.1598$ found 297.1594 .
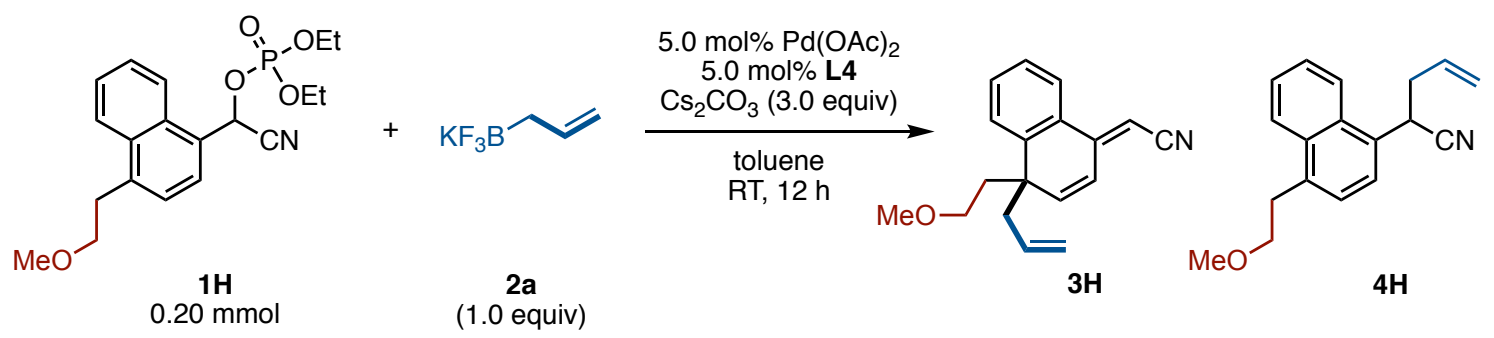

(E)-2-(4-Allyl-4-(2-methoxyethyl)naphthalen-1(4H)-ylidene)acetonitrile (3H)

Crude ${ }^{1} \mathrm{H}$ NMR showed $\mathbf{3 H}$ and $\mathbf{4 H}$ was generated in $68 \%$ yield $(\mathbf{3 H}: 4 \mathbf{H}=97: 3)$. Purification by Isolera $^{\circledR}$ with a Biotage SNAP Ultra column (hexane to hexane/EtOAc $\left.=10: 1\right)$ afforded $\mathbf{3 H}(32.7 \mathrm{mg}$, $62 \%$ yield) as a white solid. mp 68-69 ${ }^{\circ} \mathrm{C}:{ }^{1} \mathrm{H} \mathrm{NMR}\left(400 \mathrm{MHz}, \mathrm{CDCl}_{3}\right) \delta 7.69(\mathrm{~d}, J=8.4 \mathrm{~Hz}, 1 \mathrm{H})$, 7.51-7.44 (m, 2H), 7.33-7.28 (m, 1H), 7.08 (d, $J=10.8 \mathrm{~Hz}, 1 \mathrm{H}), 6.20$ (dd, $J=10.8,1.2 \mathrm{~Hz}, 1 \mathrm{H}), 5.73$ 
(d, $J=1.2 \mathrm{~Hz}, 1 \mathrm{H}), 5.37-5.24(\mathrm{~m}, 1 \mathrm{H}), 4.91-4.82(\mathrm{~m}, 2 \mathrm{H}), 3.13(\mathrm{~s}, 3 \mathrm{H}), 3.10-3.01(\mathrm{~m}, 1 \mathrm{H}), 2.89-2.81$ (m, 1H), 2.64 (dd, $J=13.6,7.2 \mathrm{~Hz}, 1 \mathrm{H}), 2.48$ (dd, $J=13.6,7.2 \mathrm{~Hz}, 1 \mathrm{H}), 2.35-2.24$ (m, 1H), $2.11-$ $2.01(\mathrm{~m}, 1 \mathrm{H}) ;{ }^{13} \mathrm{C}$ NMR $\left(101 \mathrm{MHz}, \mathrm{CDCl}_{3}\right) \delta 148.8,143.2,141.3,132.5,130.8,129.5,126.9,126.7$, 124.4, 123.2, 118.4, 118.1, 88.6, 69.0, 58.5, 47.9, 44.1, 41.5; HRMS (DART) $m / z$ calcd for $\mathrm{C}_{18} \mathrm{H}_{23} \mathrm{~N}_{2} \mathrm{O}$ $\left[\mathrm{M}+\mathrm{NH}_{4}\right]^{+}: 283.1805$ found 283.1798 .

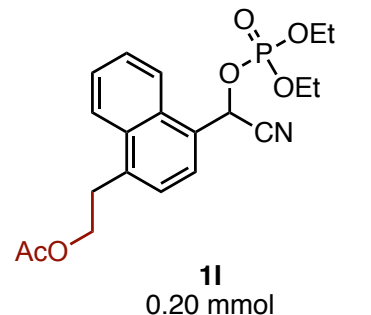

$0.20 \mathrm{mmol}$

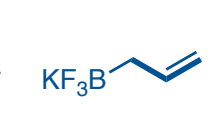

$2 \mathbf{a}$
$(1.0$ equiv

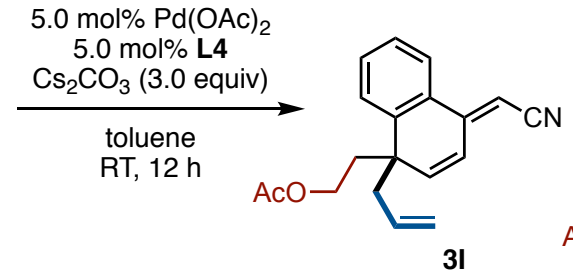<smiles>C=CCC(C#N)c1ccc(CCOC)c2ccccc12</smiles>

41

\section{(E)-2-(1-Allyl-4-(cyanomethylene)-1,4-dihydronaphthalen-1-yl)ethyl acetate (3I)}

Crude ${ }^{1} \mathrm{H}$ NMR showed 3I and 4I was generated in 73\% yield (3I:4I = 93:7). Purification by Isolera $^{\circledR}$ with a Biotage SNAP Ultra column (hexane to hexane/EtOAc $\left.=10: 1\right)$ afforded 3I $(35.0 \mathrm{mg}$, $60 \%$ yield) as a white solid. mp 61-62 ${ }^{\circ} \mathrm{C}:{ }^{1} \mathrm{H}$ NMR $\left(400 \mathrm{MHz}, \mathrm{CDCl}_{3}\right) \delta 7.69(\mathrm{~d}, J=8.0 \mathrm{~Hz}, 1 \mathrm{H})$, 7.52-7.44 (m, 2H), 7.34-7.28 (m, 1H), $7.11(\mathrm{~d}, J=10.0 \mathrm{~Hz}, 1 \mathrm{H}), 6.18$ (d, $J=10.0 \mathrm{~Hz}, 1 \mathrm{H}), 5.75$ (s, $1 \mathrm{H}), 5.37-5.25(\mathrm{~m}, 1 \mathrm{H}), 4.93-4.85(\mathrm{~m}, 2 \mathrm{H}), 3.84-3.75(\mathrm{~m}, 1 \mathrm{H}), 3.67-3.58(\mathrm{~m}, 1 \mathrm{H}), 2.63(\mathrm{dd}, J=14.0$, $7.6 \mathrm{~Hz}, 1 \mathrm{H}), 2.47(\mathrm{dd}, J=14.0,7.6 \mathrm{~Hz}, 1 \mathrm{H}), 2.43-2.34(\mathrm{~m}, 1 \mathrm{H}), 2.14-2.04(\mathrm{~m}, 1 \mathrm{H}), 1.84(\mathrm{~s}, 3 \mathrm{H}) ;{ }^{13} \mathrm{C}$ NMR (101 MHz, $\left.\mathrm{CDCl}_{3}\right) \delta 170.7,148.6,142.4,140.8,132.3,130.9,129.6,127.1,126.7,124.9,123.4$, 118.7, 118.0, 89.1, 61.1, 48.0, 44.2, 40.2, 20.7; HRMS (DART) $\mathrm{m} / z$ calcd for $\mathrm{C}_{19} \mathrm{H}_{23} \mathrm{~N}_{2} \mathrm{O}_{2}\left[\mathrm{M}+\mathrm{NH}_{4}\right]^{+}$: 311.1754 found 311.1749 .
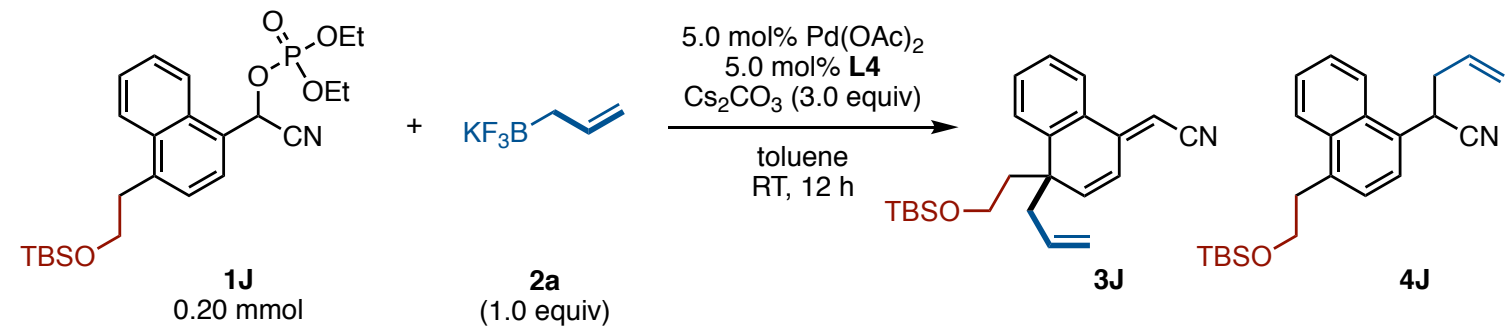

(E)-2-(4-Allyl-4-(2-((tert-butyldimethylsilyl)oxy)ethyl)naphthalen-1(4H)-ylidene)acetonitrile (3J)

Crude ${ }^{1} \mathrm{H}$ NMR showed 3J and $\mathbf{4 J}$ was generated in 70\% yield (3J:4J $\left.=93: 7\right)$. Purification by Isolera $^{\circledR}$ with a Biotage SNAP Ultra column (hexane to hexane/EtOAc $\left.=10: 1\right)$ afforded 3J $(42.1 \mathrm{mg}$, $58 \%$ yield) as a colorless oil. ${ }^{1} \mathrm{H}$ NMR $\left(400 \mathrm{MHz}, \mathrm{CDCl}_{3}\right) \delta 7.68(\mathrm{~d}, J=8.4 \mathrm{~Hz}, 1 \mathrm{H}), 7.49-7.43(\mathrm{~m}$, $2 \mathrm{H}), 7.32-7.27(\mathrm{~m}, 1 \mathrm{H}), 7.05(\mathrm{~d}, J=10.0 \mathrm{~Hz}, 1 \mathrm{H}), 6.20(\mathrm{dd}, J=1.2 \mathrm{~Hz}, 1 \mathrm{H}), 5.72(\mathrm{~d}, J=1.2 \mathrm{~Hz}, 1 \mathrm{H})$, 5.35-5.23 (m, 1H), 4.88-4.81 (m, 2H), 3.37-3.27 (m, 1H), 3.17-3.08 (m, 1H), $2.61(\mathrm{dd}, J=14.4,7.6$ $\mathrm{Hz}, 1 \mathrm{H}), 2.46$ (dd, $J=14.4,7.6 \mathrm{~Hz}, 1 \mathrm{H}), 2.31-2.22$ (m, 1H), 2.07-1.98 (m, 1H), 0.79 (s, 9H), -0.11 (s, $3 \mathrm{H}),-0.12(\mathrm{~s}, 3 \mathrm{H}) ;{ }^{13} \mathrm{C}$ NMR $\left(101 \mathrm{MHz}, \mathrm{CDCl}_{3}\right) \delta 149.0,143.5,141.5,132.6,130.7,129.6,126.8$, 126.7, 124.1, 123.2, 118.3, 118.2, 88.3, 59.6, 48.0, 44.7, 44.3, 25.8, 18.1, -5.5; HRMS (ESI) $\mathrm{m} / z$ calcd for $\mathrm{C}_{23} \mathrm{H}_{32} \mathrm{NOSi}[\mathrm{M}+\mathrm{H}]^{+}: 366.2248$ found 366.2246 . 


\section{Procedure for Dearomative Reaction using Allyltributyltin (2b)}<smiles>CCOP(=O)(O)OC(C#N)c1ccc(C)c2ccccc12</smiles>

$1 \mathrm{~A}$ $0.20 \mathrm{mmol}$

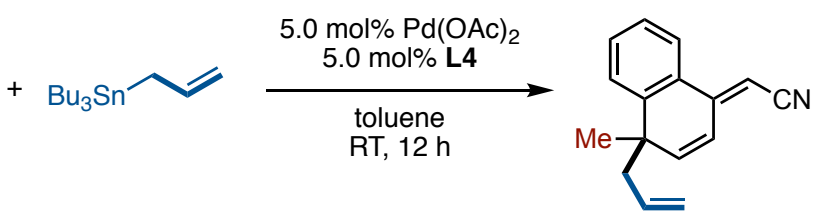

3A<smiles>C=CCC(C#N)c1ccc(C)c2ccccc12</smiles>

4A

To an 8-mL glass tube equipped with a screw cap containing a magnetic stirring bar was dried with a heat-gun in vacuo and filled with $\mathrm{N}_{2}$ after cooling to room temperature. To this tube were added $\mathrm{Pd}(\mathrm{OAc})_{2}(2.25 \mathrm{mg}, 10.0 \mu \mathrm{mol}, 5.0 \mathrm{~mol} \%)$, and tris(3,5-dimethoxyphenyl)phosphine (L4: $4.42 \mathrm{mg}$, $10.0 \mu \mathrm{mol}, 5.0 \mathrm{~mol} \%$ ). The tube was placed under vacuum and refilled $\mathrm{N}_{2}$ gas three times. To this tube were added allyltributyltin (2b: $66.2 \mathrm{mg}, 0.200 \mathrm{mmol}, 1.0$ equiv) and a solution of $\mathbf{1 A}$ (66.7 $\mathrm{mg}, 0.200$ mmol, 1.0 equiv) in toluene $(1.0 \mathrm{~mL})$. The tube was sealed with a screw cap. After stirring the mixture at room temperature for $12 \mathrm{~h}$, the mixture was passed through a short alumina pad with hexane/EtOAc $=3: 1$ as an eluent. The filtrate was concentrated in vacuo. Crude ${ }^{1} \mathrm{H}$ NMR showed $\mathbf{3 A}$ and $\mathbf{4 A}$ was generated in $82 \%$ yield $(\mathbf{3 A : 4 A}=96: 4)$.

\section{Procedure for Dearomative Reaction in $1 \mathrm{mmol}$ Scale}<smiles>CCOP(=O)(OCC)OC(C#N)c1ccc(C)c2ccccc12</smiles>

$1 \mathrm{~A}$

$1.0 \mathrm{mmol}$

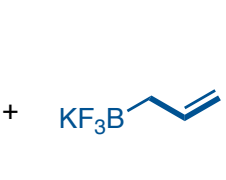

$2 \mathrm{a}$ (1.0 equiv)

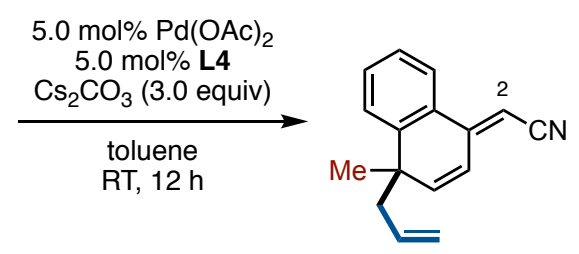

3A<smiles>C=CCC(C#N)c1ccc(C)c2ccccc12</smiles>

4A

To an 20-mL glass tube equipped with a screw cap containing a magnetic stirring bar and cesium carbonate (985 mg, $3.00 \mathrm{mmol}, 3.0$ equiv) was dried with a heat-gun in vacuo and filled with $\mathrm{N}_{2}$ after cooling to room temperature. To this tube were added $\mathrm{Pd}(\mathrm{OAc})_{2}(11.2 \mathrm{mg}, 50.0 \mu \mathrm{mol}, 5.0 \mathrm{~mol} \%)$, tris(3,5-dimethoxyphenyl)phosphine $\quad(\mathbf{L} 4: \quad 22.1 \quad \mathrm{mg}, \quad 50.0 \quad \mu \mathrm{mol}, \quad 5.0 \quad \mathrm{~mol} \%)$, potassium allyltrifluoroborate (2a: $148 \mathrm{mg}, 1.00 \mathrm{mmol}, 1.0$ equiv). The tube was placed under vacuum and refilled $\mathrm{N}_{2}$ gas three times. To this tube was added a solution of $\mathbf{1 A}$ (338.0 mg, $1.00 \mathrm{mmol}, 1.0$ equiv) in toluene $(5.0 \mathrm{~mL})$. The tube was sealed with a screw cap. After stirring the mixture at room temperature for $12 \mathrm{~h}$, the mixture was passed through a short alumina pad with hexane/EtOAc $=3: 1$ as an eluent. The filtrate was concentrated in vacuo. Crude ${ }^{1} \mathrm{H}$ NMR showed $\mathbf{3 A}$ and $\mathbf{4 A}$ was generated in $55 \%$ yield $(3 \mathrm{~A}: 4 \mathbf{A}=96: 4)$. Purification by Isolera ${ }^{\circledR}$ with a Biotage SNAP Ultra column (hexane to hexane/EtOAc $=10: 1)$ afforded $\mathbf{3 A}(113.6 \mathrm{mg}, 51 \%$ yield $)$ as a colorless oil. 


\section{Derivatization of Products}

\section{1,6-Addition of 3A using ${ }^{n} \mathrm{BuLi} / \mathrm{MeCN}$ for the Synthesis of}

\section{2,2'-((3S*,4R*)-4-allyl-4-methyl-3,4-dihydronaphthalene-1,3-diyl)diacetonitrile (5)}<smiles>C=CCC1(C)C=CC(=CC#N)c2ccccc21</smiles>

$3 \mathbf{A}$

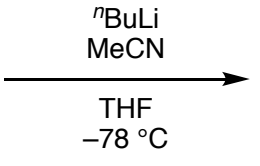

$-78^{\circ} \mathrm{C}$<smiles>C=CC[C@]1(C)c2ccccc2C(CC#N)=CC1N</smiles>

5

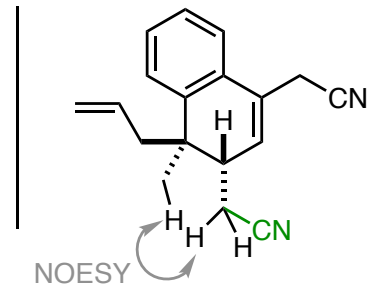

A $15 \mathrm{~mL}$ drum-vial was dried up by a heat-gun in vacuo and filled with $\mathrm{N}_{2}$ after cooling to room temperature. To this vial was added $\mathrm{MeCN}(36.1 \mu \mathrm{L}, 0.686 \mathrm{mmol}, 3.0$ equiv) and THF $(0.50 \mathrm{~mL})$ under the stream of $\mathrm{N}_{2}$ gas, and then the solution was cooled to $-78^{\circ} \mathrm{C}$. To the solution was added $n$-butyllithium (1.59 $\mathrm{M}$ in hexane, $0.431 \mathrm{~mL}, 0.686 \mathrm{mmol}, 3.0$ equiv) dropwise at $-78{ }^{\circ} \mathrm{C}$. After stirring for $45 \mathrm{~min}$., a solution of $\mathbf{3 A}(50.6 \mathrm{mg}, 0.229 \mathrm{mmol})$ in THF $(1.0 \mathrm{~mL})$ was added dropwise into the vial. After stirring $4 \mathrm{~h}$ at $-78^{\circ} \mathrm{C}$, the reaction was quenched with $\mathrm{NH}_{4} \mathrm{Cl}$ aq. and extracted three times with EtOAc. Combined organic layer was dried over $\mathrm{Na}_{2} \mathrm{SO}_{4}$, filtrated, and concentrated in vacuo. The mixture was purified by PTLC (hexane/EtOAc $=3: 1)$ to afford 5 ( $24.6 \mathrm{mg}, 41 \%$ yield, $\mathrm{dr}=$ 10:1) as a yellow oil. ${ }^{1} \mathrm{H} \mathrm{NMR}\left(400 \mathrm{MHz}, \mathrm{CDCl}_{3}\right) \delta$ 7.39-7.28 (m, 2H), 7.26-7.15 (m, 2H), 6.31 (d, $J$ $=6.4 \mathrm{~Hz}, 1 \mathrm{H}), 5.62-5.46(\mathrm{~m}, 1 \mathrm{H}), 5.11-4.94(\mathrm{~m}, 2 \mathrm{H}), 3.59(\mathrm{~s}, 2 \mathrm{H}), 2.72-2.61(\mathrm{~m}, 1 \mathrm{H}), 2.44(\mathrm{dd}, J=$ 16.8, 5.2 Hz, 1H), $2.31(\mathrm{dd}, J=13.6,6.4 \mathrm{~Hz}, 1 \mathrm{H}), 2.24(\mathrm{dd}, J=13.6,8.4 \mathrm{~Hz}, 1 \mathrm{H}), 2.14(\mathrm{dd}, J=16.8$, $10.0 \mathrm{~Hz}, 1 \mathrm{H}), 1.37$ (s, 3H); ${ }^{13} \mathrm{C}$ NMR $\left(101 \mathrm{MHz}, \mathrm{CDCl}_{3}\right) \delta 140.4,133.7,130.0,129.3,128.1,127.7$, 127.3, 126.2, 123.0, 118.8, 118.6, 117.0, 44.4, 39.8, 39.4, 21.8, 20.8, 17.4; HRMS (DART) $\mathrm{m} / z$ calcd for $\mathrm{C}_{18} \mathrm{H}_{22} \mathrm{~N}_{3}\left[\mathrm{M}+\mathrm{NH}_{4}\right]^{+}: 280.1808$ found 280.1803 .

\section{1,6-Addition of 3A using MeCN/DBU for the Synthesis of}

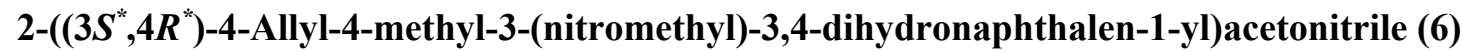<smiles>C=CCC1(C)C=CC(=CC#N)c2ccccc21</smiles>

3A

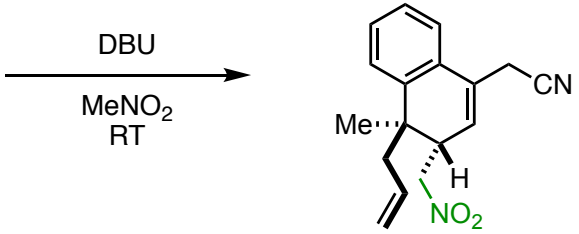

6

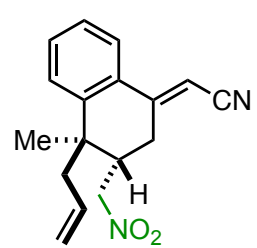

6'
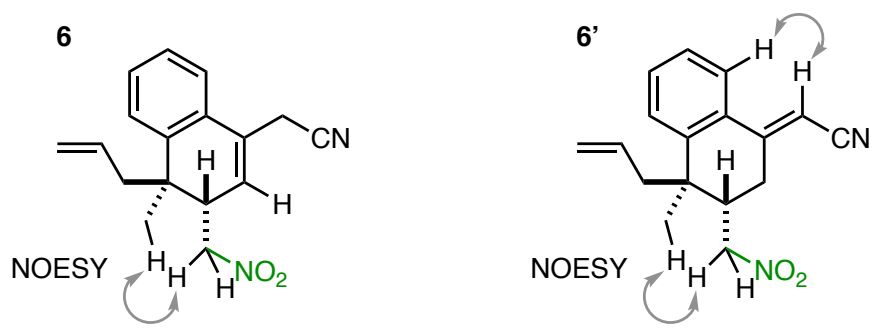
To a solution of 3A $(46.9 \mathrm{mg}, 0.212 \mu \mathrm{mol})$ in $\mathrm{MeNO}_{2}(1.0 \mathrm{~mL})$ was added DBU $(639 \mu \mathrm{L}, 4.24$ mmol, 20 equiv). After stirring the mixture at room temperature for several hours with monitoring reaction progress with $\mathrm{TLC}$, the reaction was quenched with $\mathrm{NaHCO}_{3}$ aq. and extracted three times with EtOAc. The combined organic layer was dried over $\mathrm{Na}_{2} \mathrm{SO}_{4}$, filtrated, and concentrated in vacuo. The mixture was purified by PTLC (hexane/EtOAc = 5:1) to afford a mixture of 6 and $\mathbf{6}$ ' (39.5 mg, $66 \%$ yield, 6:6' $=50: 50$ ). Further purification by Isolera ${ }^{\circledR}$ with a Biotage SNAP Ultra C18 column $\left(\mathrm{H}_{2} \mathrm{O}\right.$ to $\left.\mathrm{H}_{2} \mathrm{O} / \mathrm{MeCN}=1: 1\right)$ was performed for the characterization to give pure $\mathbf{6}$ and $\mathbf{6}$ ' as a colorless oil.

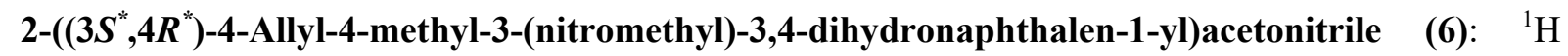
NMR (400 MHz, $\left.\mathrm{CDCl}_{3}\right) \delta$ 7.38-7.28 (m, 2H), 7.25-7.18 (m, 2H), 6.14 (d, J=6.4 Hz, 1H), 5.63-5.49 (m, 1H), 5.09 (d, $J=10.0 \mathrm{~Hz}, 1 \mathrm{H}), 5.00(\mathrm{~d}, J=16.0 \mathrm{~Hz}, 1 \mathrm{H}), 4.46$ (dd, $J=12.4,5.2 \mathrm{~Hz}, 1 \mathrm{H}), 4.07$ (dd, $J=12.4,10.4 \mathrm{~Hz}, 1 \mathrm{H}), 3.55(\mathrm{~s}, 2 \mathrm{H}), 3.23-3.12(\mathrm{~m}, 1 \mathrm{H}), 2.38-2.24(\mathrm{~m}, 2 \mathrm{H}), 1.37(\mathrm{~s}, 3 \mathrm{H}),{ }^{13} \mathrm{C} \mathrm{NMR}$ $\left(101 \mathrm{MHz}, \mathrm{CDCl}_{3}\right) \delta 140.6,133.5,129.9,129.4,128.6,127.3,126.2,126.0,123.2,119.0,116.8,75.6$, 44.4, 41.0, 39.4, 21.8, 20.6; HRMS (ESI) $m / z$ calcd for $\mathrm{C}_{17} \mathrm{H}_{18} \mathrm{~N}_{2} \mathrm{O}_{2} \mathrm{Na}[\mathrm{M}+\mathrm{Na}]^{+}: 305.1260$ found 305.1258 .

\section{2-((3S $\left.S^{*} 4 R^{*}, E\right)-4-A l l y l-4-m e t h y l-3-(n i t r o m e t h y l)-3,4-d i h y d r o n a p h t h a l e n-1(2 H)$-ylidene)acetonitril} e (6'): ${ }^{1} \mathrm{H}$ NMR (400 MHz, $\left.\mathrm{CDCl}_{3}\right) \delta 7.59$ (dd, $\left.J=8.0,1.2 \mathrm{~Hz}, 1 \mathrm{H}\right), 7.48-7.41$ (m, 1H), 7.35-7.27 (m, $2 \mathrm{H}), 5.85(\mathrm{t}, J=1.6 \mathrm{~Hz}, 1 \mathrm{H}), 5.68-5.56(\mathrm{~m}, 1 \mathrm{H}), 5.19-5.07(\mathrm{~m}, 2 \mathrm{H}), 4.45(\mathrm{dd}, J=12.0,4.0 \mathrm{~Hz}, 1 \mathrm{H})$, $4.03(\mathrm{dd}, J=12.0,9.2 \mathrm{~Hz}, 1 \mathrm{H}), 3.28-3.16(\mathrm{~m}, 1 \mathrm{H}), 2.94-2.85(\mathrm{~m}, 2 \mathrm{H}), 2.50(\mathrm{dd}, J=14.8,8.0 \mathrm{~Hz}, 1 \mathrm{H})$, $2.28(\mathrm{dd}, J=14.8,6.8 \mathrm{~Hz}, 1 \mathrm{H}), 1.39(\mathrm{~s}, 3 \mathrm{H}) ;{ }^{13} \mathrm{C} \mathrm{NMR}\left(101 \mathrm{MHz}, \mathrm{CDCl}_{3}\right) \delta 154.6,143.2,132.6,131.6$, $130.5,127.4,126.7,124.7,119.6,117.0,93.9,76.8,46.1,39.9,39.1,29.5,23.6$; HRMS (ESI) $\mathrm{m} / \mathrm{z}$ calcd for $\mathrm{C}_{17} \mathrm{H}_{18} \mathrm{~N}_{2} \mathrm{O}_{2} \mathrm{Na}[\mathrm{M}+\mathrm{Na}]^{+}: 305.1260$ found 305.1258 .

\section{Hydrogenation of $3 \mathrm{~A}$ for the Synthesis of}

\section{2-((1R*,4R*)-4-Methyl-4-propyl-1,2,3,4-tetrahydronaphthalen-1-yl)acetonitrile (7)}

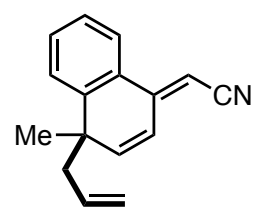

3A

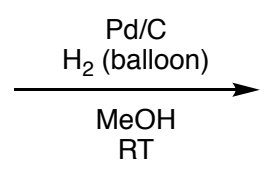
$7.33 \mu \mathrm{mol}, 2.0 \mathrm{~mol} \%$ ) and equipped with $\mathrm{H}_{2}$ balloon (1 atm) then stirred for overnight at room temperature. The mixture was passed through a pad of Celite ${ }^{\circledR}$. The mixture was concentrated in vacuo, and then purified by PTLC (hexane/EtOAc $=10: 1)$ to afford a mixture of 7 and 7 ' $(76.1 \mathrm{mg}, 95 \%$ yield, 7:7' $=2.8: 1$ ). Further purification by PTLC (hexane/EtOAc $=10: 1)$ for the characterization was performed to give pure $\mathbf{7}$ and $\mathbf{7}$ ' as a colorless oil. 


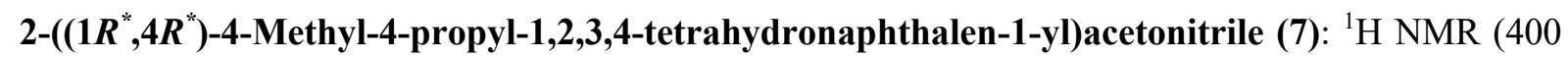
$\left.\mathrm{MHz}, \mathrm{CDCl}_{3}\right) \delta 7.28(\mathrm{~d}, J=7.6 \mathrm{~Hz}, 1 \mathrm{H}), 7.24-7.18(\mathrm{~m}, 1 \mathrm{H}), 7.18-7.08(\mathrm{~m}, 2 \mathrm{H}), 3.23-3.12(\mathrm{~m}, 1 \mathrm{H})$, $2.65(\mathrm{dd}, J=17.2,6.0 \mathrm{~Hz}, 1 \mathrm{H}), 2.56(\mathrm{dd}, J=17.2,9.6 \mathrm{~Hz}, 1 \mathrm{H}), 2.14-2.02(\mathrm{~m}, 1 \mathrm{H}), 1.98-1.83(\mathrm{~m}, 2 \mathrm{H})$, $1.73(\mathrm{td}, J=13.6,4.4 \mathrm{~Hz}, 1 \mathrm{H}), 1.62-1.43(\mathrm{~m}, 2 \mathrm{H}), 1.34-1.18(\mathrm{~m}, 4 \mathrm{H}), 1.12-0.97(\mathrm{~m}, 1 \mathrm{H}), 0.88(\mathrm{t}, J=$ $7.6 \mathrm{~Hz}, 3 \mathrm{H}) ;{ }^{13} \mathrm{C} \mathrm{NMR}\left(101 \mathrm{MHz}, \mathrm{CDCl}_{3}\right) \delta 144.8,136.3,128.5,127.3,127.2,125.8,118.9,45.6,37.0$, $35.6,30.9,30.0,24.7,23.5,17.7,14.7$; HRMS (ESI) $m / z$ calcd for $\mathrm{C}_{16} \mathrm{H}_{21} \mathrm{NNa}[\mathrm{M}+\mathrm{Na}]^{+}: 250.1566$ found 250.1565 .

2-((1S $\left.\left.S^{*}, 4 R^{*}\right)-4-M e t h y l-4-p r o p y l-1,2,3,4-t e t r a h y d r o n a p h t h a l e n-1-y l\right) a c e t o n i t r i l e ~\left(7^{\prime}\right):{ }^{1} \mathrm{H}$ NMR (400 $\left.\mathrm{MHz}, \mathrm{CDCl}_{3}\right) \delta 7.31(\mathrm{~d}, J=7.6 \mathrm{~Hz}, 1 \mathrm{H}), 7.24-7.18(\mathrm{~m}, 1 \mathrm{H}), 7.18-7.11(\mathrm{~m}, 2 \mathrm{H}), 3.22-3.11(\mathrm{~m}, 1 \mathrm{H})$, $2.72(\mathrm{dd}, J=17.2,5.2 \mathrm{~Hz}, 1 \mathrm{H}), 2.61(\mathrm{dd}, J=17.2,9.6 \mathrm{~Hz}, 1 \mathrm{H}), 2.15-2.03(\mathrm{~m}, 1 \mathrm{H}), 1.90-1.77(\mathrm{~m}, 2 \mathrm{H})$, $1.68-1.56(\mathrm{~m}, 2 \mathrm{H}), 1.52-1.42(\mathrm{~m}, 1 \mathrm{H}), 1.35-1.20(\mathrm{~m}, 4 \mathrm{H}), 1.19-1.05(\mathrm{~m}, 1 \mathrm{H}), 0.86(\mathrm{t}, J=7.2 \mathrm{~Hz}$, $3 \mathrm{H}),{ }^{13} \mathrm{C}$ NMR $\left(101 \mathrm{MHz}, \mathrm{CDCl}_{3}\right) \delta 145.6,135.9,127.6,127.2,127.1,125.8,118.9,46.0,36.8,35.5$, 31.3, 29.7, 24.7, 24.4, 17.6, 14.8; HRMS (ESI) $m / z$ calcd for $\mathrm{C}_{16} \mathrm{H}_{21} \mathrm{NNa}[\mathrm{M}+\mathrm{Na}]^{+}: 250.1566$ found 250.1565 .

DIBAL Reduction of 3A for the Synthesis of (E)-2-(4-Allyl-4-methylnaphthalen-1(4H)-ylidene) Acetaldehyde (8)

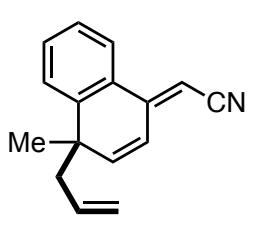

3A

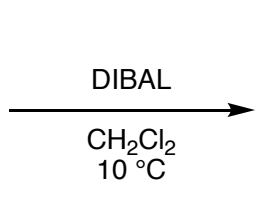

$10^{\circ} \mathrm{C}$

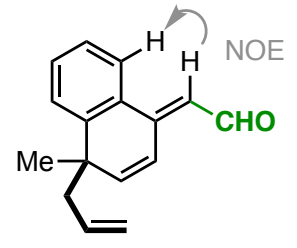

8

A solution of $\mathbf{3 A}(41.1 \mathrm{mg}, 0.19 \mathrm{mmol})$ in $\mathrm{CH}_{2} \mathrm{Cl}_{2}(1.0 \mathrm{~mL})$ was cooled to $10{ }^{\circ} \mathrm{C}$. To this mixture was added DIBAL (1.0 M in hexane, $0.56 \mathrm{~mL}, 0.56 \mathrm{mmol}, 3.0$ equiv) slowly. After stirring for $3 \mathrm{~h}$ at $10{ }^{\circ} \mathrm{C}$, the reaction was quenched with $1.0 \mathrm{M} \mathrm{HCl}$ aq. and extracted three times with EtOAc. Combined organic layer was dried over $\mathrm{Na}_{2} \mathrm{SO}_{4}$, filtrated, and concentrated in vacuo. The mixture was purified by PTLC (hexane/EtOAc $=9: 1)$ to afford $8\left(16.4 \mathrm{mg}, 39 \%\right.$ yield) as a yellow oil. ${ }^{1} \mathrm{H}$ NMR $\left(400 \mathrm{MHz}, \mathrm{CDCl}_{3}\right) \delta 10.36(\mathrm{~d}, J=8.0 \mathrm{~Hz}, 1 \mathrm{H}), 7.84(\mathrm{~d}, J=8.0 \mathrm{~Hz}, 1 \mathrm{H}), 7.54-7.42(\mathrm{~m}, 3 \mathrm{H}), 7.36-7.28$ (m, 1H), $6.53(\mathrm{~d}, J=8.0 \mathrm{~Hz}, 1 \mathrm{H}), 6.27(\mathrm{dd}, J=10.0,2.0 \mathrm{~Hz}, 1 \mathrm{H}), 5.46-5.30(\mathrm{~m}, 1 \mathrm{H}), 4.96-4.83$ (m, 2H), $2.64(\mathrm{dd}, J=14.4,7.6 \mathrm{~Hz}, 1 \mathrm{H}), 2.46(\mathrm{dd}, J=14.4,7.6 \mathrm{~Hz}, 1 \mathrm{H}), 1.46(\mathrm{~s}, 3 \mathrm{H}) ;{ }^{13} \mathrm{C}$ NMR $(101 \mathrm{MHz}$, $\left.\mathrm{CDCl}_{3}\right) \delta 190.7,146.8,145.3,144.5,133.5,130.5,130.0,126.8,124.3,120.0,119.7,118.0,48.1,41.3$, 29.1 (one peak is missing due to overlapping); HRMS (ESI) $\mathrm{m} / z$ calcd for $\mathrm{C}_{16} \mathrm{H}_{17} \mathrm{O}[\mathrm{M}+\mathrm{H}]^{+}$: 225.1274 found 225.1274 . 


\section{Effect of Parameters and Limitation}

\section{Screening of Ligands}

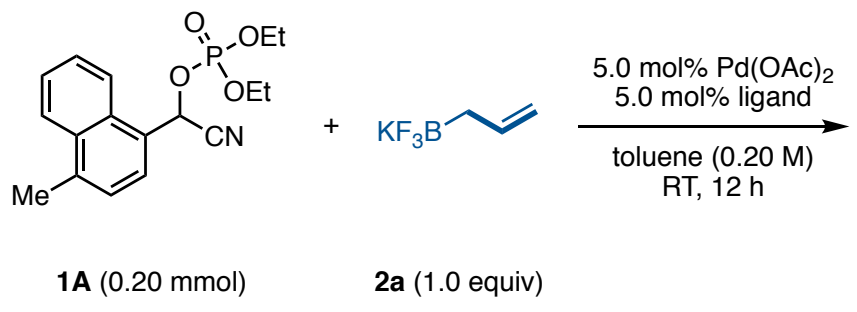

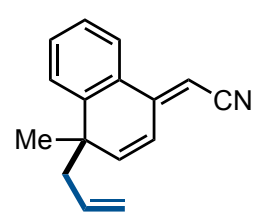

3A<smiles>C=CCC(C#N)c1ccc(C)c2ccccc12</smiles>

4A

\begin{tabular}{|c|c|c|c|c|c|}
\hline \multirow[b]{2}{*}{ entry } & \multirow[b]{2}{*}{ ligand } & \multicolumn{4}{|c|}{ NMR Yield (\%) } \\
\hline & & $1 \mathrm{~A}$ & 3A & 4A & ratio (3A:4A) \\
\hline 1 & $\mathrm{IPr} \cdot \mathrm{HCl}$ & 100 & 0 & 0 & n.a. \\
\hline 2 & $\mathrm{SIPr} \cdot \mathrm{HCl}$ & 100 & 0 & 0 & n.a. \\
\hline 3 & IMes·HCl & 100 & 0 & 0 & n.a. \\
\hline 4 & SIMes $\cdot \mathrm{HCl}$ & 100 & 0 & 0 & n.a. \\
\hline 5 & $\mathrm{PPhCy}_{2}$ & 92 & 4 & 0 & n.a. \\
\hline 6 & dpph & 92 & 1 & 1 & n.a. \\
\hline 7 & L1 & 43 & 46 & 7 & $87: 13$ \\
\hline 8 & $\mathrm{P}(p \text {-anisyl })_{3}$ & 58 & 29 & 4 & $88: 12$ \\
\hline 9 & $\mathrm{P}(p \text {-tolyl })_{3}$ & 60 & 29 & 4 & $88: 12$ \\
\hline 10 & $\mathrm{P}(m \text {-tolyl })_{3}$ & 46 & 42 & 4 & $91: 9$ \\
\hline 11 & $\mathrm{P}(\text { o-tolyl })_{3}$ & 100 & 3 & 0 & n.a. \\
\hline 12 & $\mathrm{P}(2 \text {-furyl })_{3}$ & 51 & 22 & 26 & $46: 64$ \\
\hline 13 & $\mathrm{P}(1-\text { naph })_{3}$ & 81 & 11 & 0 & 100:0 \\
\hline 14 & L2 & 79 & 32 & 3 & $91: 9$ \\
\hline 15 & L3 & 49 & 37 & 3 & $93: 7$ \\
\hline 16 & L4 & 60 & 42 & 2 & $95: 5$ \\
\hline 17 & L5 & 100 & 0 & 0 & n.a. \\
\hline 18 & L6 & 67 & 41 & 5 & $89: 11$ \\
\hline 19 & L7 & 69 & 39 & 6 & $87: 13$ \\
\hline 20 & L8 & 100 & 0 & 0 & n.a. \\
\hline 21 & L9 & 80 & 5 & 0 & n.a. \\
\hline 22 & $\mathrm{PPh}_{3}$ & 66 & 31 & 5 & $86: 14$ \\
\hline
\end{tabular}<smiles>CN(C)c1ccc(P(c2ccccc2)c2ccccc2)cc1</smiles>

L1

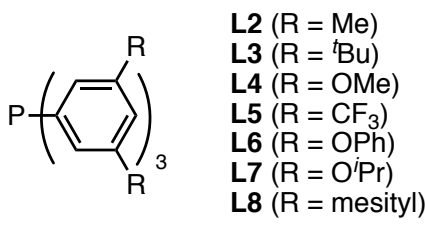<smiles>COc1cc(Br)c(P)c(Br)c1</smiles>

L9

[a] Yields were determined by ${ }^{1} \mathrm{H}$ NMR using $\mathrm{CH}_{2} \mathrm{Br}_{2}$ as an internal standard.

\section{Effect of meta-Substituted Arylphosphines on the Site-Selectivity}<smiles>CCOP(=O)(OCC)OC(C#N)c1ccc(C)c2ccccc12</smiles>

$1 \mathrm{~A}(0.20 \mathrm{mmol})$<smiles>C=CC[AsH2+]</smiles>

2a (1.0 equiv)

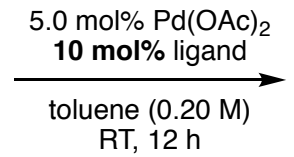
$\mathrm{RT}, 12 \mathrm{~h}$<smiles>C=CCC1(C)C=C/C(=C\C#N)c2ccccc21</smiles>

3A<smiles>C=CCC(C#N)c1ccc(C)c2ccccc12</smiles>

4A

Yield of $\mathbf{3 A + 4 A}$<smiles>COc1ccccc1P(c1ccccc1OC)c1ccccc1OC</smiles>

$17 \%$

(3A:4A = 65:35)<smiles>COc1ccc(P(c2ccc(OC)cc2)c2ccc(OC)cc2)cc1</smiles>

(3A:4A = 73:27)<smiles>COc1cc(OC)cc(P(c2cc(OC)cc(OC)c2)c2cc(OC)cc(OC)c2)c1</smiles>

$53 \%$

(3A:4A = 91:9) 


\section{Screening of Solvents}<smiles>CCOP(=O)(OCC)OC(C#N)c1ccc(C)c2ccccc12</smiles>

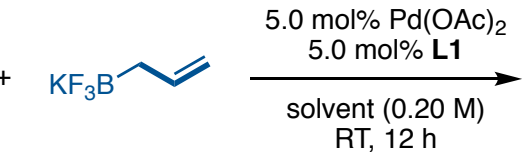

$1 \mathrm{~A}(0.20 \mathrm{mmol})$

2a (1.0 equiv)<smiles>C=CCC1(C)C=CC(=CC#N)c2ccccc21</smiles>

3A<smiles>C=CCC(C#N)c1ccc(C)c2ccccc12</smiles>

$4 A$

\begin{tabular}{cccccc}
\hline & & \multicolumn{5}{c}{ NMR yield (\%) } \\
entry & solvent & $\mathbf{1 A}$ & 3A & 4A & ratio (3A:4A) \\
\hline 1 & THF & 18 & 52 & 20 & $72: 28$ \\
2 & 1,4-dioxane & 57 & 48 & 8 & $86: 14$ \\
3 & $\mathrm{Et}_{2} \mathrm{O}$ & 34 & 36 & 14 & $72: 28$ \\
4 & $\mathrm{DME}$ & 31 & 43 & 18 & $70: 30$ \\
5 & toluene $^{2}$ & 43 & 46 & 7 & $87: 13$ \\
6 & $\mathrm{CH}_{2} \mathrm{Cl}_{2}$ & 70 & 3 & 0 & n.a. \\
$7^{b}$ & $\mathrm{CH}_{2} \mathrm{Cl}_{2}$ & 61 & 22 & 8 & $73: 27$ \\
8 & $\mathrm{CHCl}_{3}$ & 76 & 10 & 2 & $83: 17$ \\
$9^{b}$ & $\mathrm{CHCl}_{3}$ & 36 & 34 & 20 & $63: 37$ \\
10 & $\mathrm{DCE}$ & 100 & 0 & 0 & n.a. \\
11 & MeCN & 82 & 2 & trace & n.a. \\
12 & acetone & 92 & 8 & 0 & n.a. \\
13 & DMF & 96 & 4 & 0 & n.a. \\
\hline
\end{tabular}

[a] Yields were determined by ${ }^{1} \mathrm{H}$ NMR using $\mathrm{CH}_{2} \mathrm{Br}_{2}$ as an internal standard. [b] $40^{\circ} \mathrm{C}$

\section{Effect of Additives}<smiles>CCOP(=O)(OCC)OC(C#N)c1ccc(C)c2ccccc12</smiles><smiles>C=CC[AsH3-]</smiles>

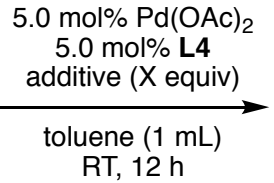

$\mathrm{RT}, 12 \mathrm{~h}$

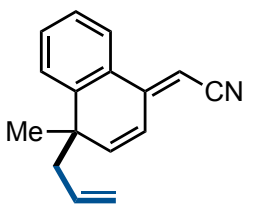

3A<smiles>C=CCC(C#N)c1ccc(C)c2ccccc12</smiles>

4A

\begin{tabular}{cccccc}
\hline & & \multicolumn{4}{c}{ NMR yield (\%) } \\
entry & additive $(\mathrm{X})$ & $\mathbf{1 A}$ & $\mathbf{3 A}$ & $\mathbf{4 A}$ & ratio $(\mathbf{3 A}: 4 \mathbf{A})$ \\
\hline 1 & none & 60 & 42 & 2 & $95: 5$ \\
2 & $\mathrm{CsF}(3.0)$ & 34 & 51 & 3 & $94: 6$ \\
3 & $\mathrm{Cs}_{2} \mathrm{CO}_{3}(3.0)$ & 39 & 68 & 2 & $97: 3$ \\
4 & $\mathrm{Cs}_{2} \mathrm{CO}_{3}(1.5)$ & 39 & 58 & 7 & $89: 11$
\end{tabular}

[a] Yields were determined by ${ }^{1} \mathrm{H}$ NMR using $\mathrm{CH}_{2} \mathrm{Br}_{2}$ as an internal standard.

\section{Effect of Leaving Groups}<smiles>Cc1ccc(C(O)C#N)c2ccccc12</smiles>

$1 \mathrm{~A}(0.20 \mathrm{mmol})$

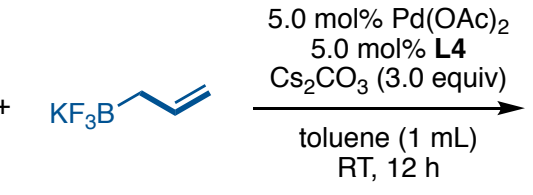

2a (1.0 equiv)<smiles>C=CCC1(C)C=CC(=CC#N)c2ccccc21</smiles>

3A

(Ar = 4-methylnaphthyl)<smiles>CCOP(=O)(OCC)OC([Mg])[Al]</smiles><smiles>COC(=O)OC([Mg])Br</smiles> 


\section{Limitation of This Method}<smiles>[R]c1ccc(C(C#N)OP(=O)(OCC)OCC)c2ccccc12</smiles>

1

$0.20 \mathrm{mmol}$

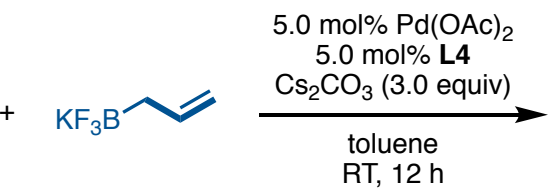

2a

(1.0 equiv)<smiles>[R]C1(CC=C)C=CC(=CC#N)c2ccccc21</smiles>

3<smiles>[R]c1ccc(C(C#N)CC=C)c2ccccc12</smiles>

NMR yield of 3+4 (3:4)<smiles>CCOP(=O)(OCC)OC(C#N)c1ccc(-c2ccccc2)c2ccccc12</smiles>

$37 \%(14: 86)$

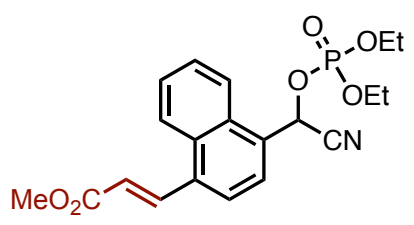

$48 \%(1:>99)$<smiles>CCOP(=O)(OCC)OC(C#N)c1cccc2ccccc12</smiles>

$2 \%(-)^{b}$<smiles>CCOP(=O)(OCC)OC(C#N)c1ccc(C)cc1</smiles>

$21 \%(0: 100)^{c}$

${ }^{b} \mathrm{P}(m \text {-Tolyl })_{3}$ was used instead of $\mathbf{L} 4$ without $\mathrm{Cs}_{2} \mathrm{CO}_{3}$.

${ }^{c}$ allylSnBu 3 was used instead of $2 a$, DPEphos was used instead of L4 and KF was used instead of $\mathrm{Cs}_{2} \mathrm{CO}_{3}$.<smiles>CCOP(=O)(OCC)OC(C#N)c1ccc(C)c2ccccc12</smiles>

$1 \mathrm{~A}$

$0.20 \mathrm{mmol}$

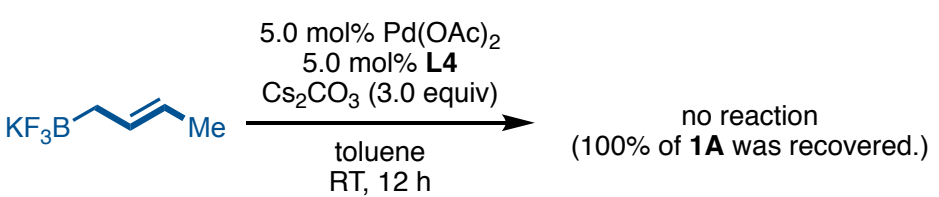

(1.0 equiv) 


\section{References}

[1] Smith, A. J.; Gawne, P. J.; Ma, M. T.; Blower, P. J.; Southworth, R.; Long, N. J. Synthesis, Gallium-68 Radiolabelling and Biological Evaluation of a Series of TriarylphosphoniumFunctionalized DO3A Chelators. Dalton Trans. 2018, 47, 15448-15457.

[2] Szigeti, M.; Dobi, Z.; Soés, T. The Goldilocks Principle in Phase Labeling. Minimalist and Orthogonal Phase Tagging for Chromatography-Free Mitsunobu Reaction. J. Org. Chem. 2018, 83, 2869-2874.

[3] Sinou, D.; Maillard, D.; Aghmiz, A.; Masdeu i-Bultó, A. M. Rhodium-Catalyzed Hydrogenation of Alkenes by Rhodium/ Tris(fluoroalkoxy)phosphane Complexes in Fluorous Biphasic System. Adv. Synth. Catal. 2003, 345, 603-611.

[4] Davis, T.; Erkey, C. Hydroformylation of Higher Olefins in Supercritical Carbon Dioxide with $\mathrm{HRh}(\mathrm{CO})\left[\mathrm{P}\left(3,5-\left(\mathrm{CF}_{3}\right)_{2}-\mathrm{C}_{6} \mathrm{H}_{3}\right)_{3}\right]_{3}$. Ind. Eng. Chem. Res. 2000, 39, 3671-3678

[5] Øien-Ødegaard, S.; Bouchevreau, B.; Hylland, K.; Wu, L.; Blom, R.; Grande, C.; Olsbye, U.; Tilset, M.; Lillerud, K. P. UiO-67-type Metal-Organic Frameworks with Enhanced Water Stability and Methane Adsorption Capacity. Inorg. Chem. 2016, 55, 1986-1991. 


\section{7. ${ }^{1} \mathrm{H},{ }^{13} \mathrm{C}$ and ${ }^{31} \mathrm{P}$ NMR Spectra}

${ }^{1} \mathrm{H}$ NMR of $\mathbf{1 A}\left(400 \mathrm{MHz}, \mathrm{CDCl}_{3}\right)$

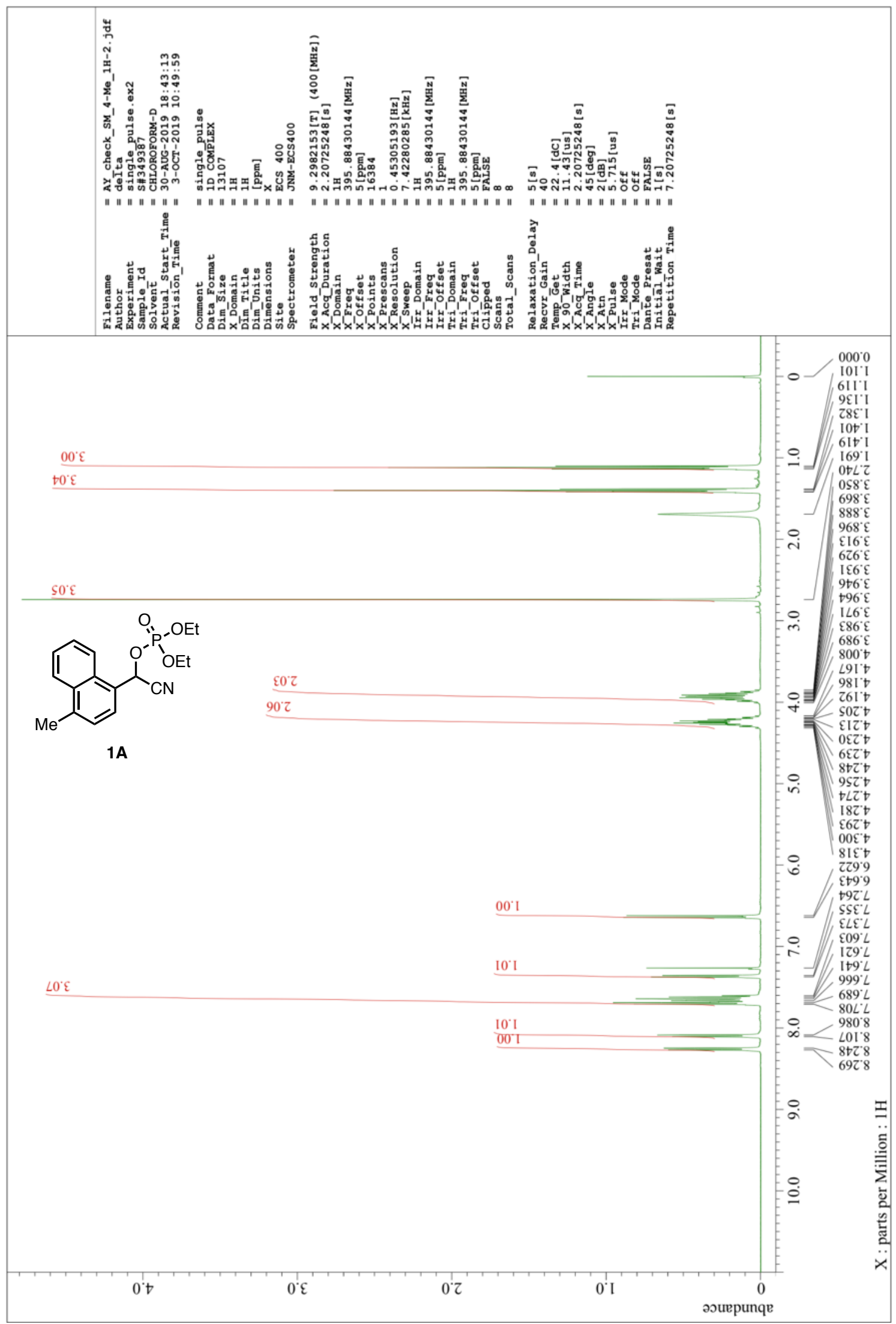


${ }^{13} \mathrm{C}$ NMR of $\mathbf{1 A}\left(101 \mathrm{MHz}, \mathrm{CDCl}_{3}\right)$

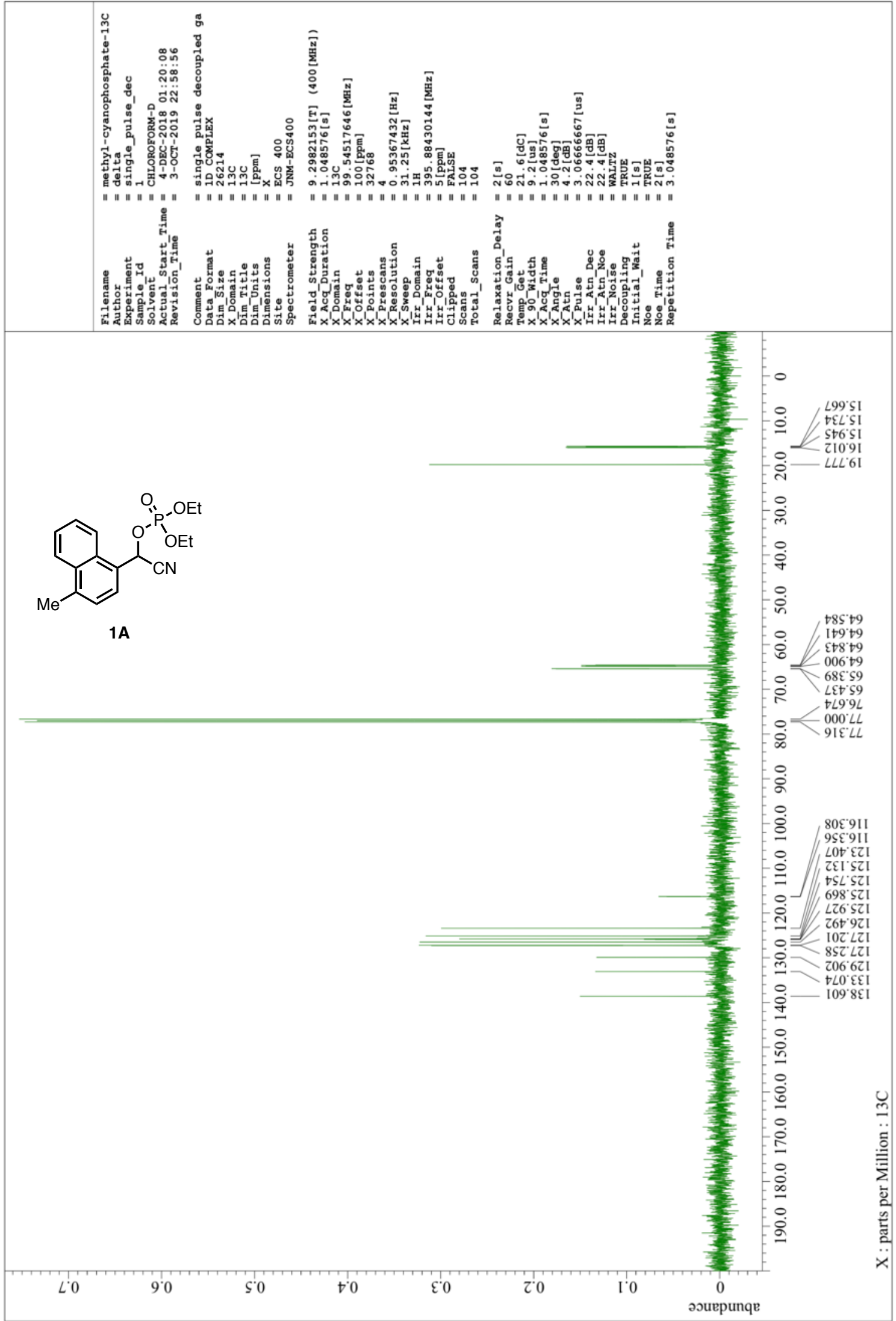




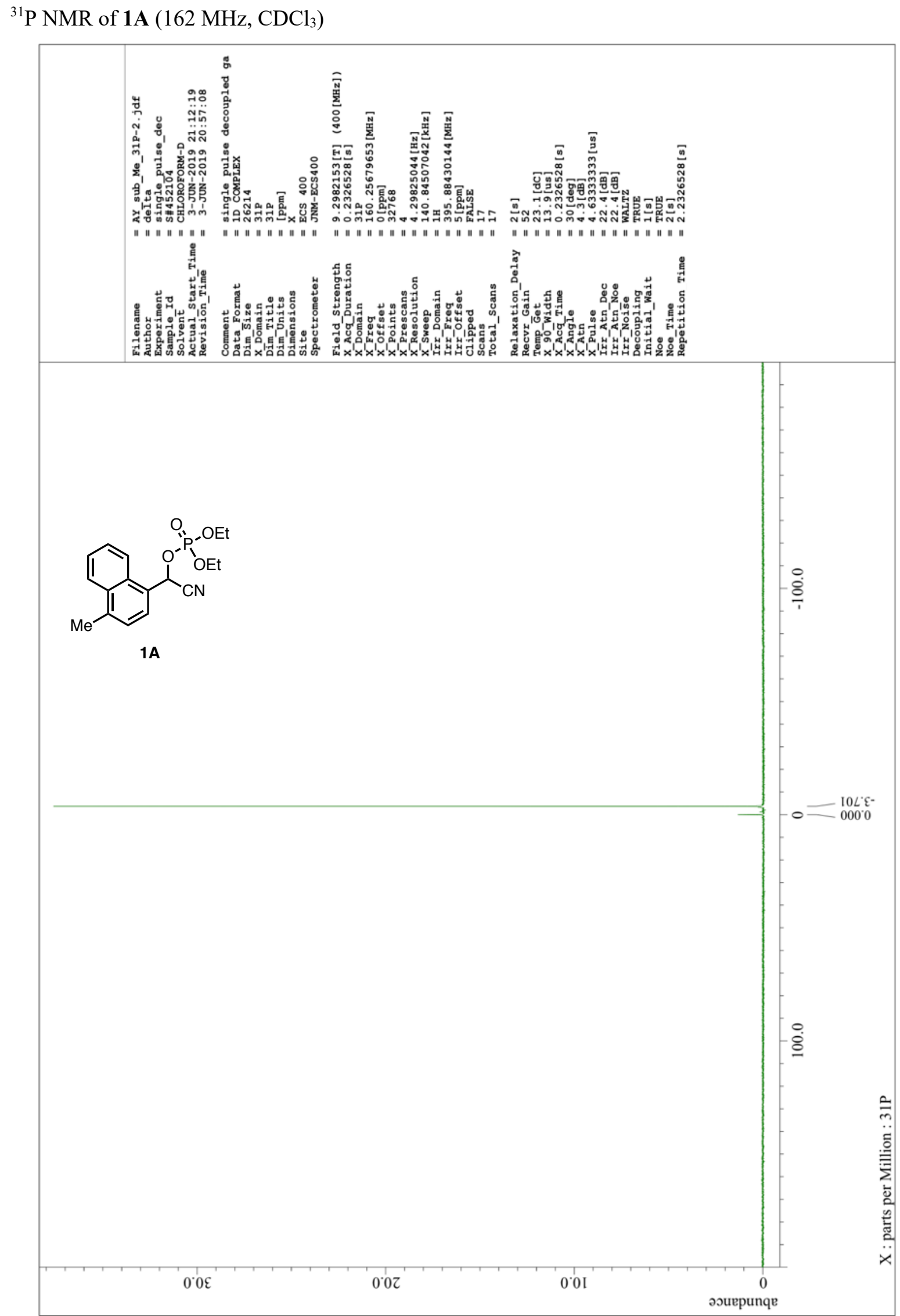


${ }^{1} \mathrm{H}$ NMR of $1 \mathbf{B}\left(400 \mathrm{MHz}, \mathrm{CDCl}_{3}\right)$

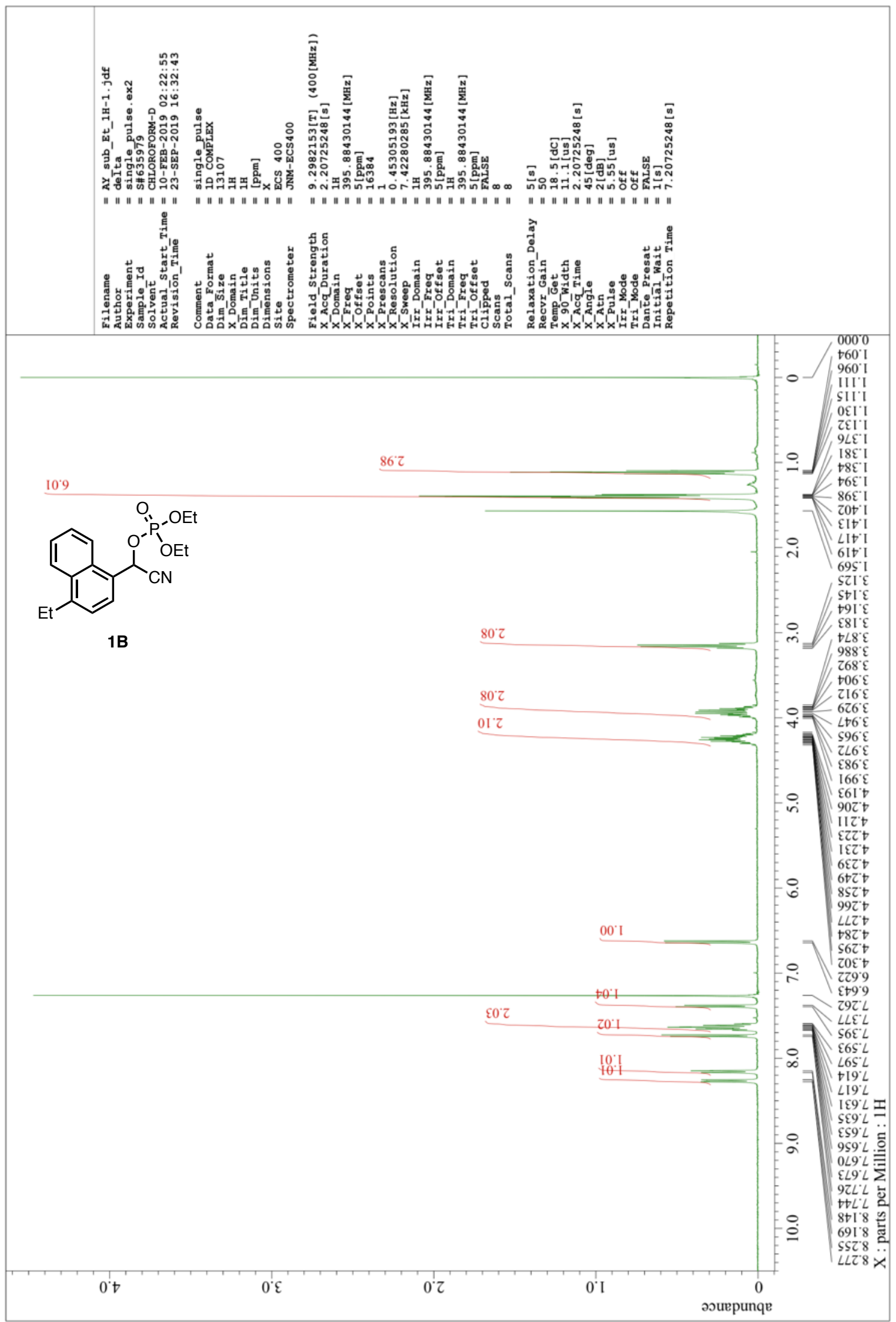


${ }^{13} \mathrm{C}$ NMR of $1 \mathbf{B}\left(101 \mathrm{MHz}, \mathrm{CDCl}_{3}\right)$

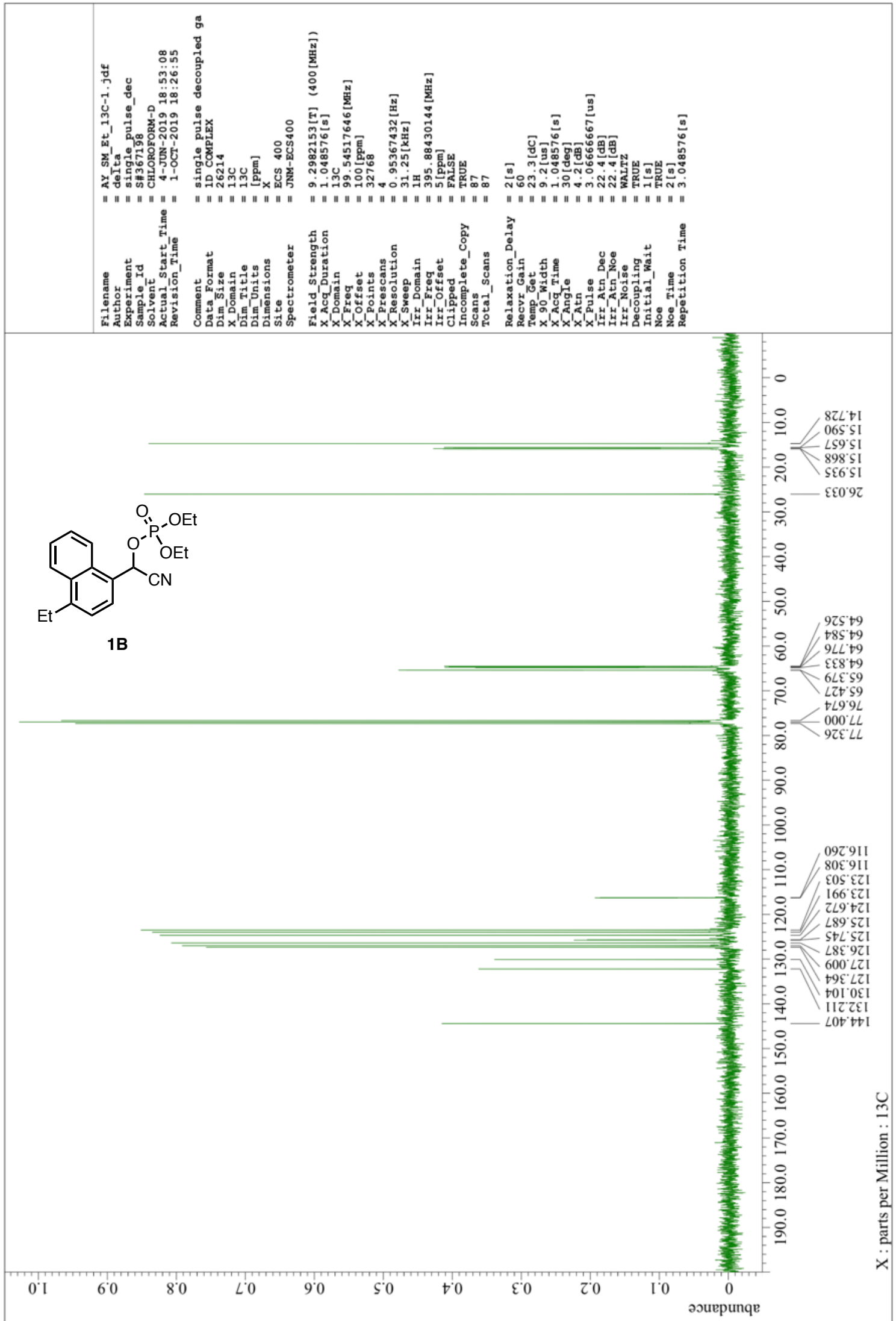




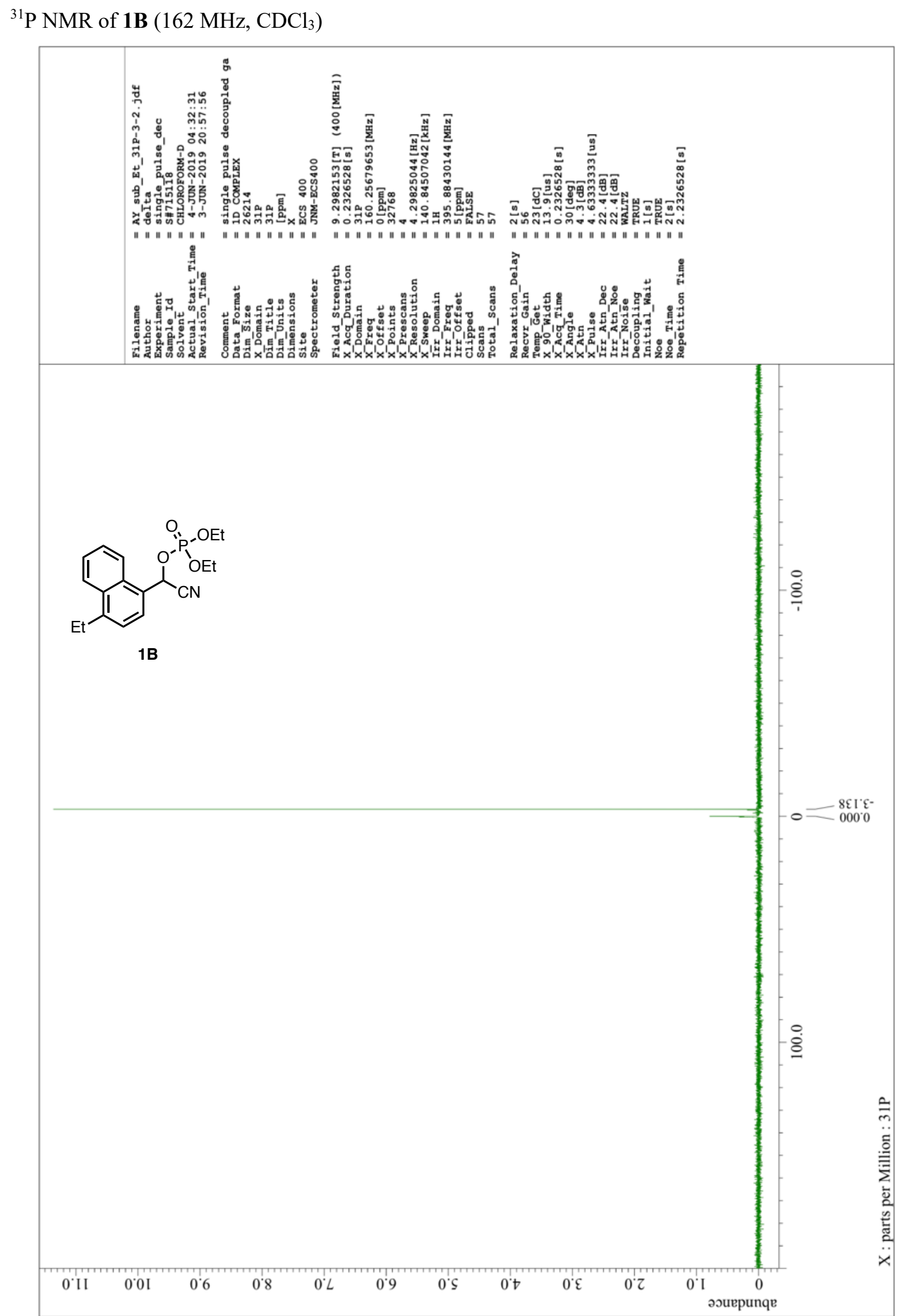


${ }^{1} \mathrm{H} \mathrm{NMR}$ of $1 \mathrm{C}\left(400 \mathrm{MHz}, \mathrm{CDCl}_{3}\right)$

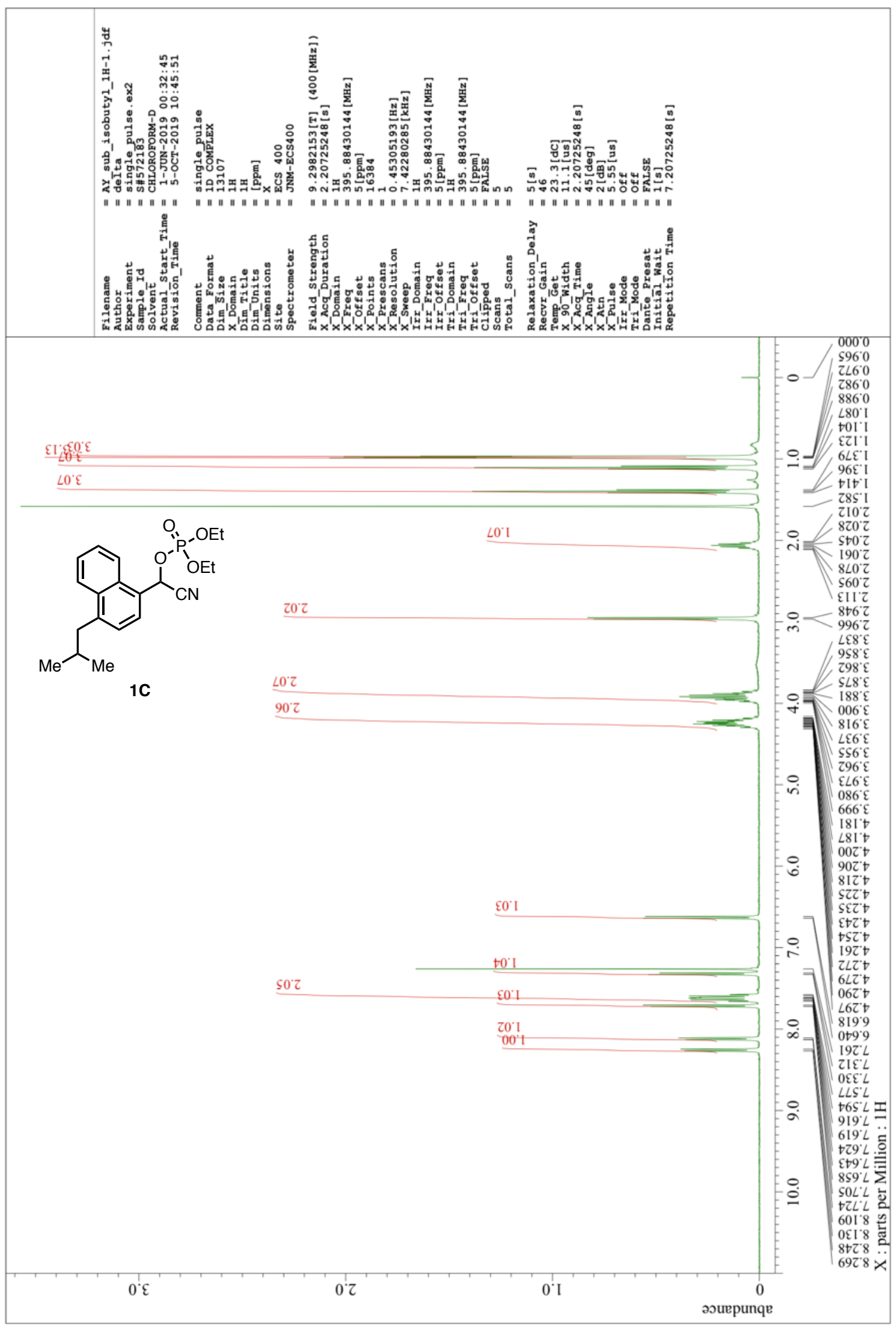


${ }^{13} \mathrm{C}$ NMR of $1 \mathrm{C}\left(101 \mathrm{MHz}, \mathrm{CDCl}_{3}\right)$

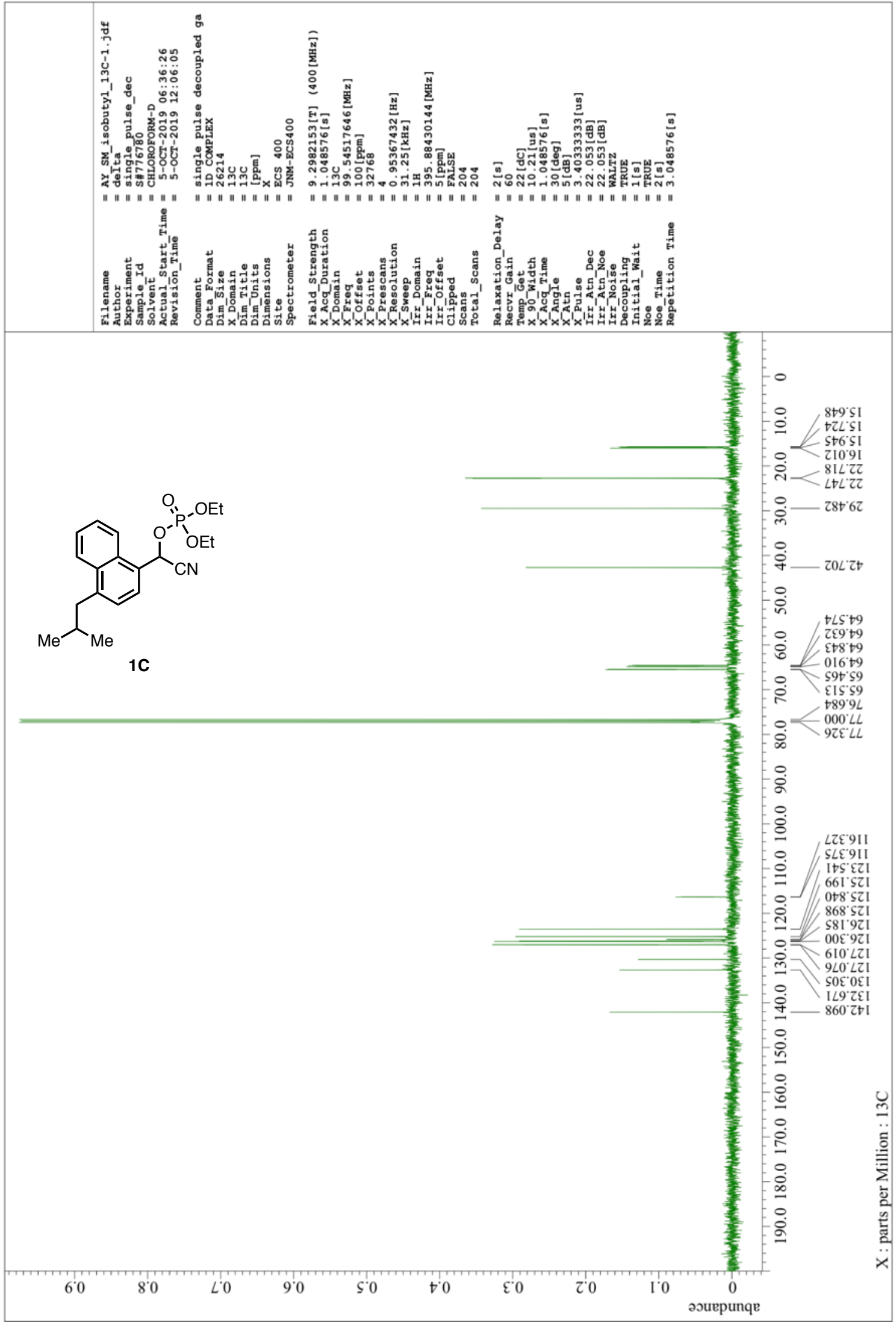




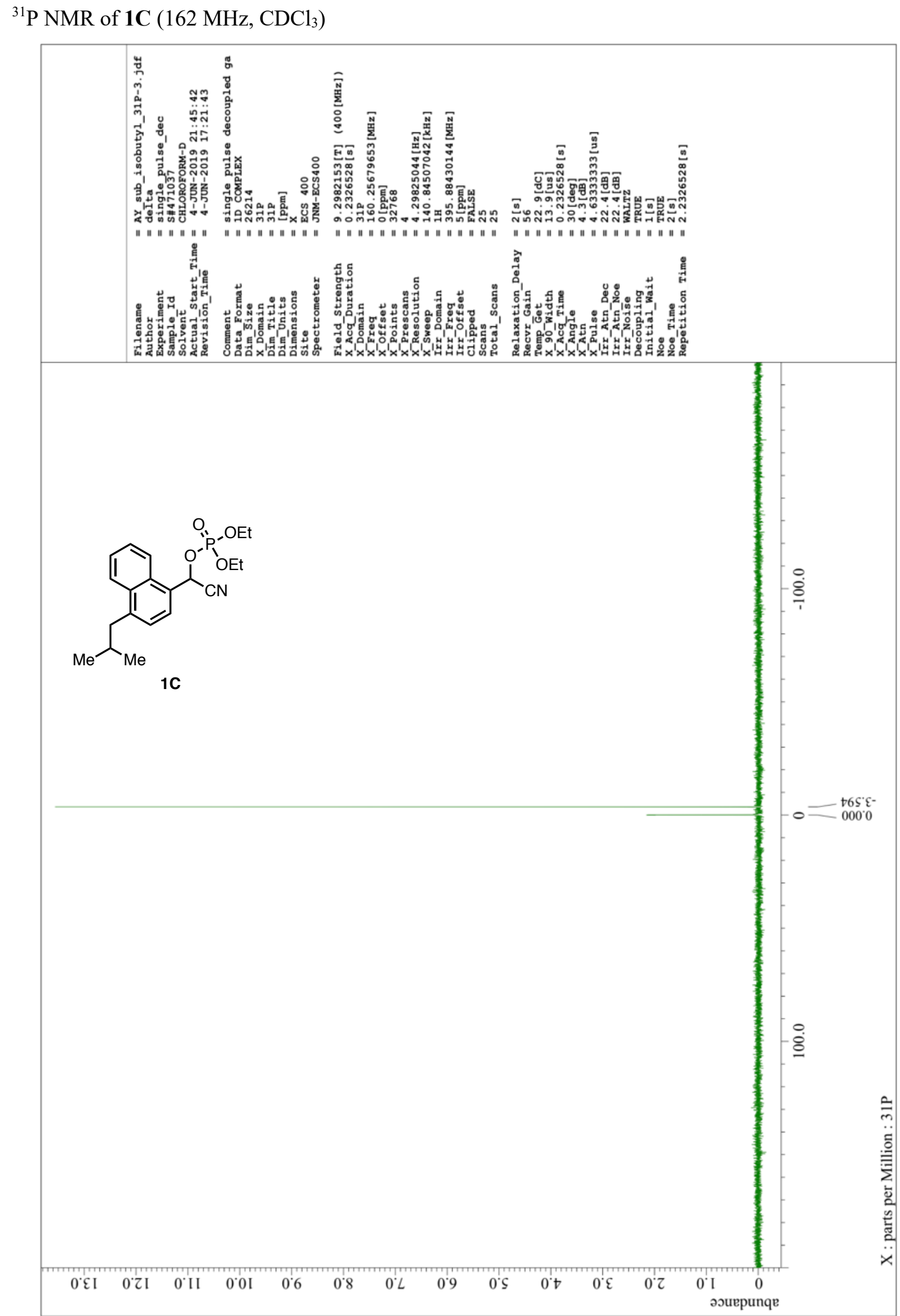


${ }^{1} \mathrm{H}$ NMR of $1 D\left(400 \mathrm{MHz}, \mathrm{CDCl}_{3}\right)$

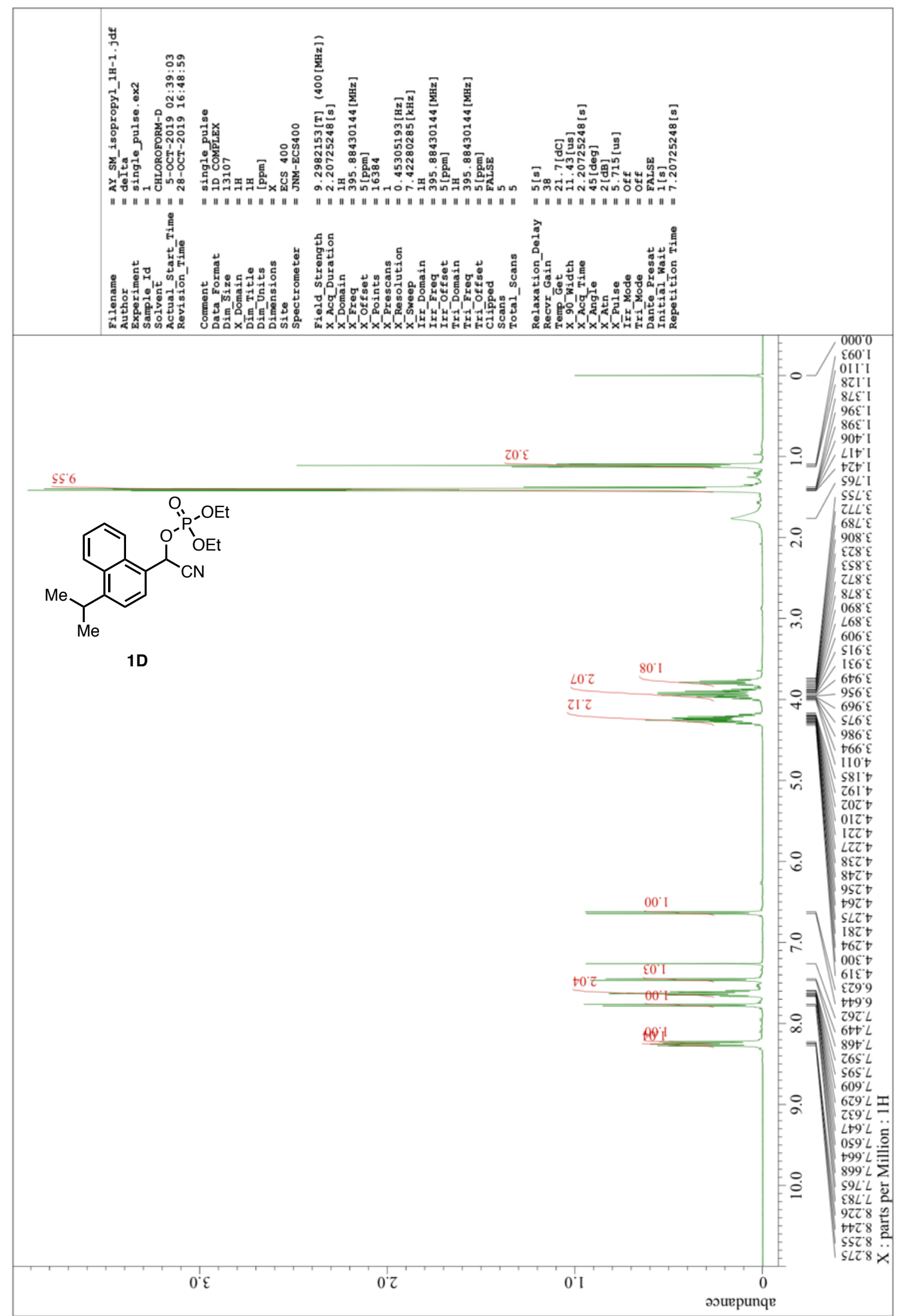


${ }^{13} \mathrm{C}$ NMR of $1 \mathrm{D}\left(101 \mathrm{MHz}, \mathrm{CDCl}_{3}\right)$

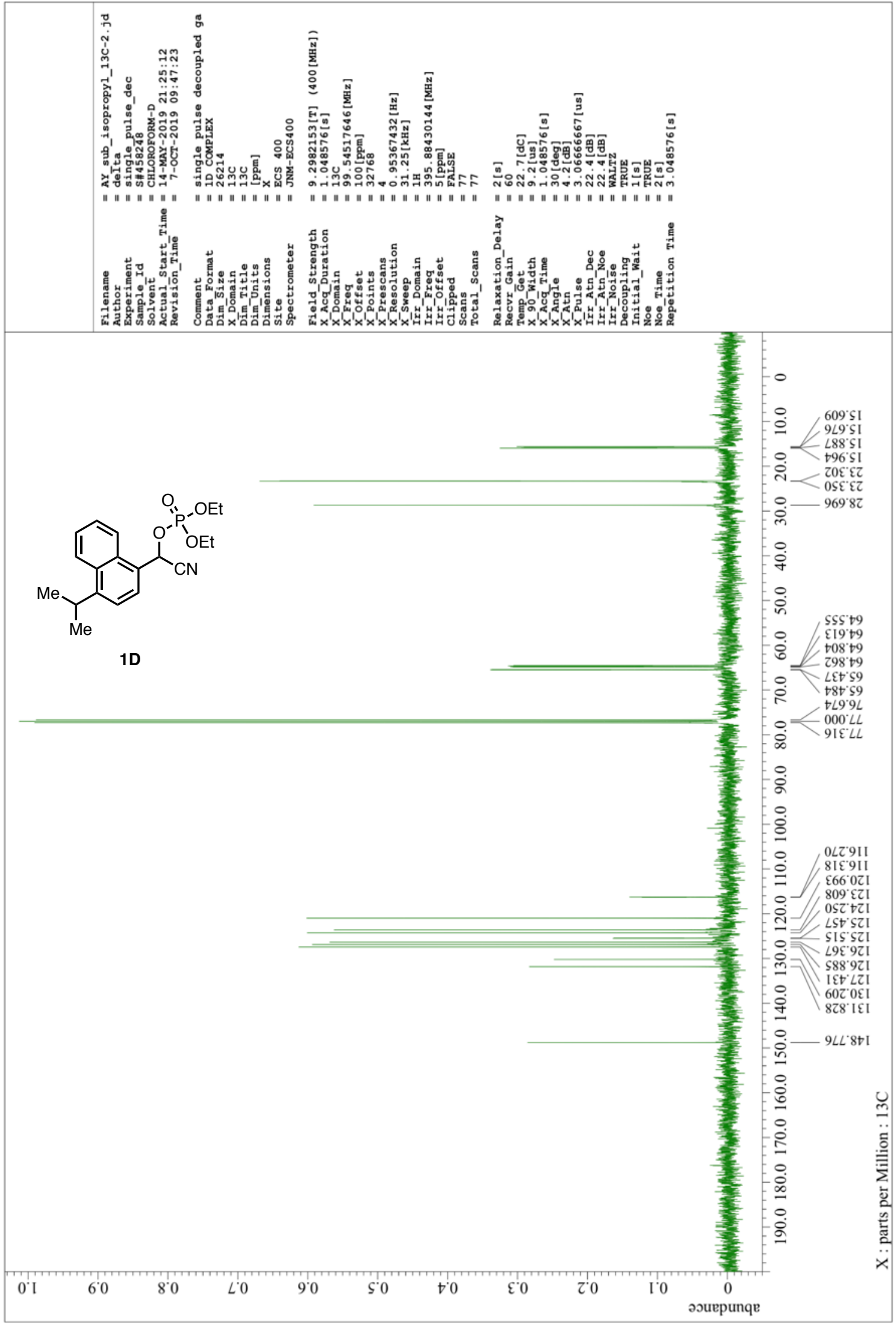




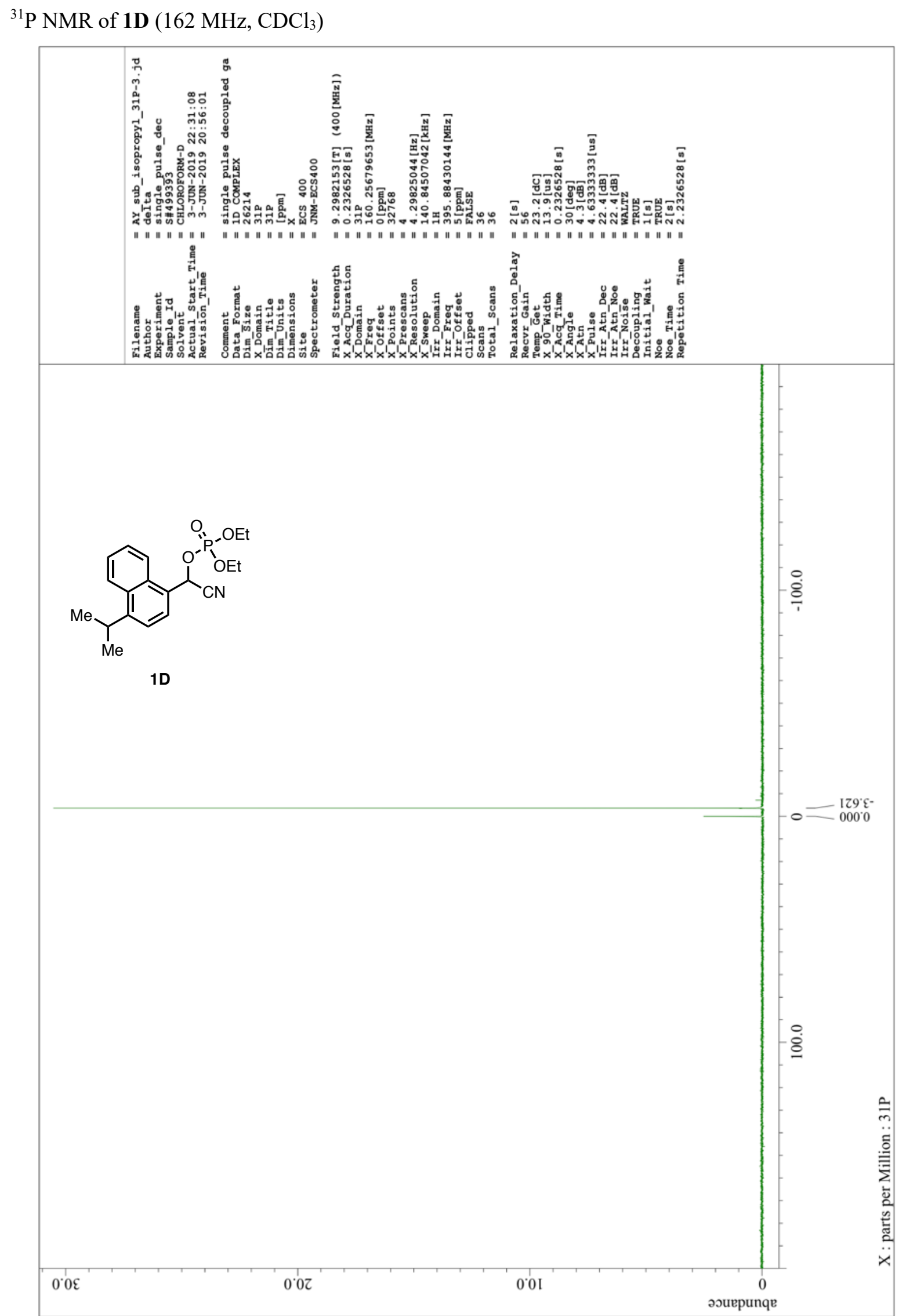


${ }^{1} \mathrm{H}$ NMR of $1 \mathbf{E}\left(400 \mathrm{MHz}, \mathrm{CDCl}_{3}\right)$

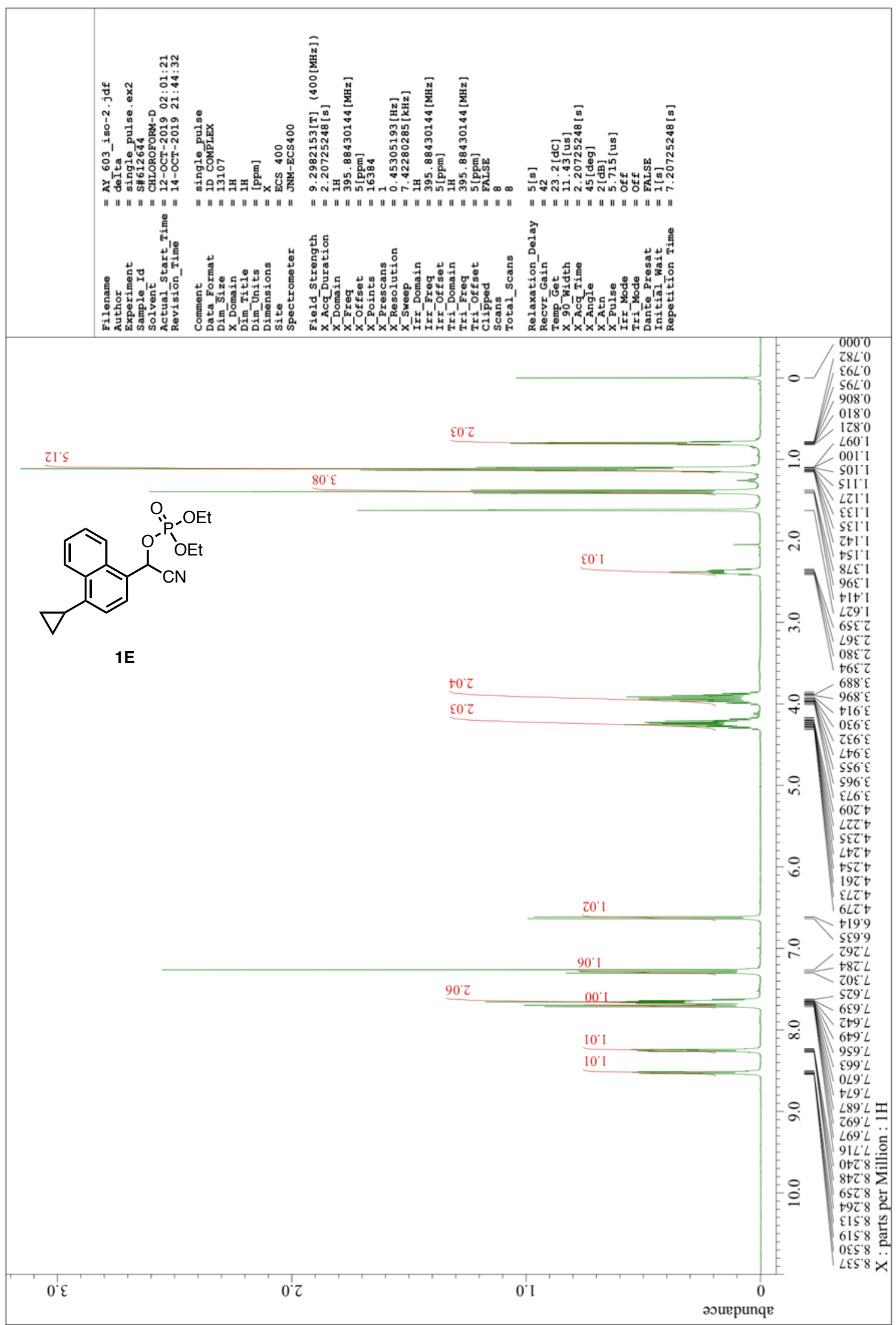


${ }^{13} \mathrm{C}$ NMR of 1E $\left(101 \mathrm{MHz}, \mathrm{CDCl}_{3}\right)$

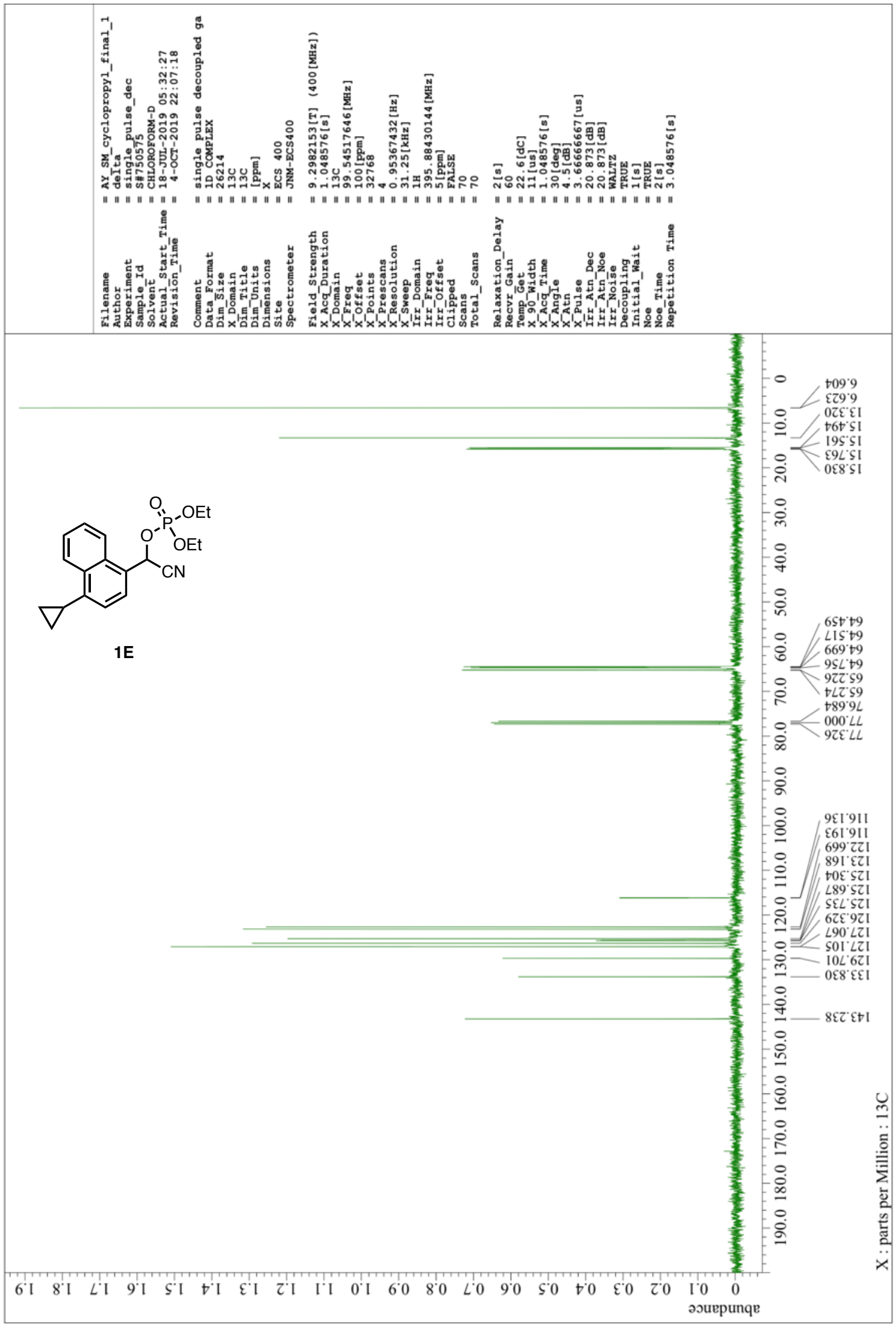




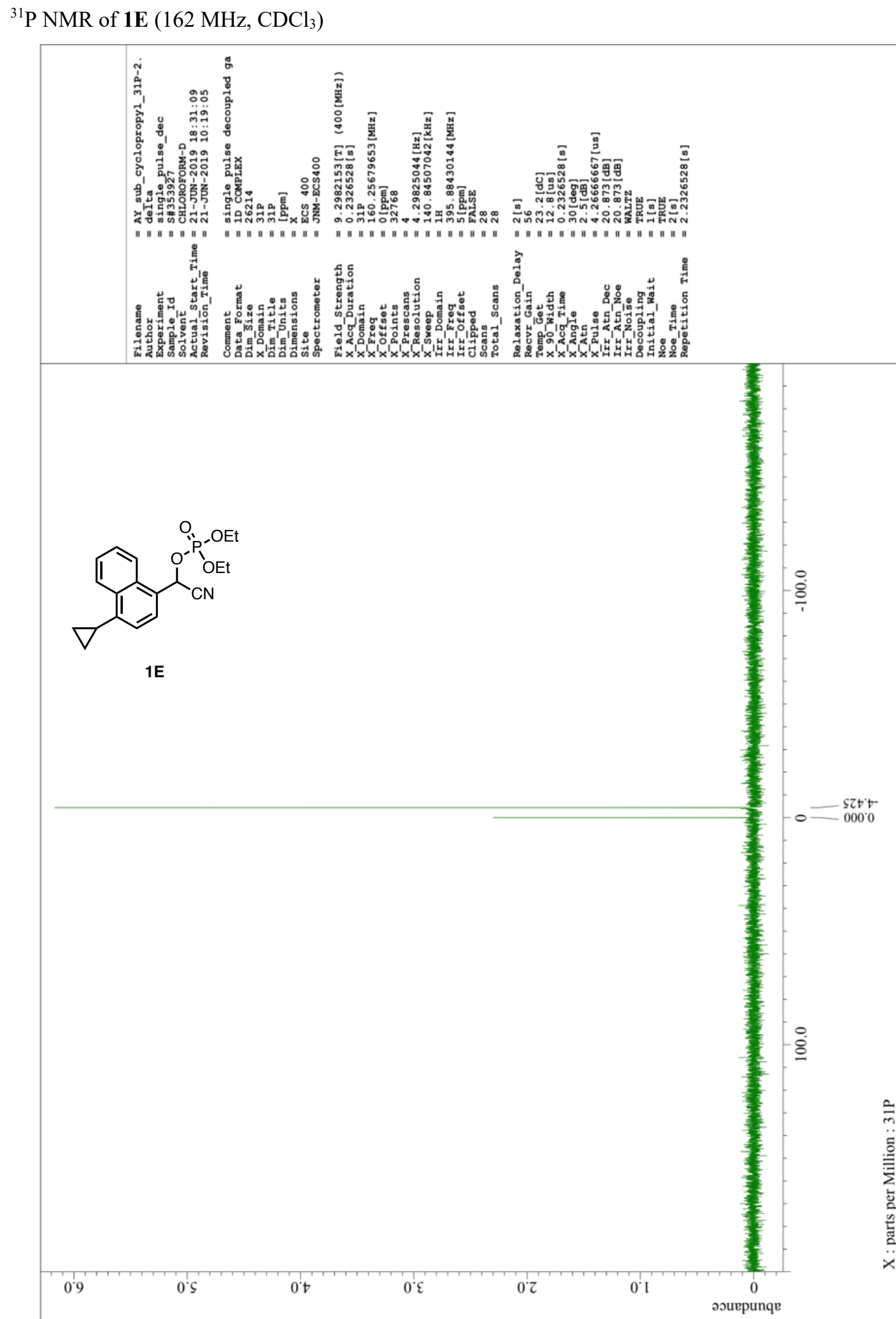


${ }^{1} \mathrm{H} \mathrm{NMR}$ of 1 F $\left(400 \mathrm{MHz}, \mathrm{CDCl}_{3}\right)$

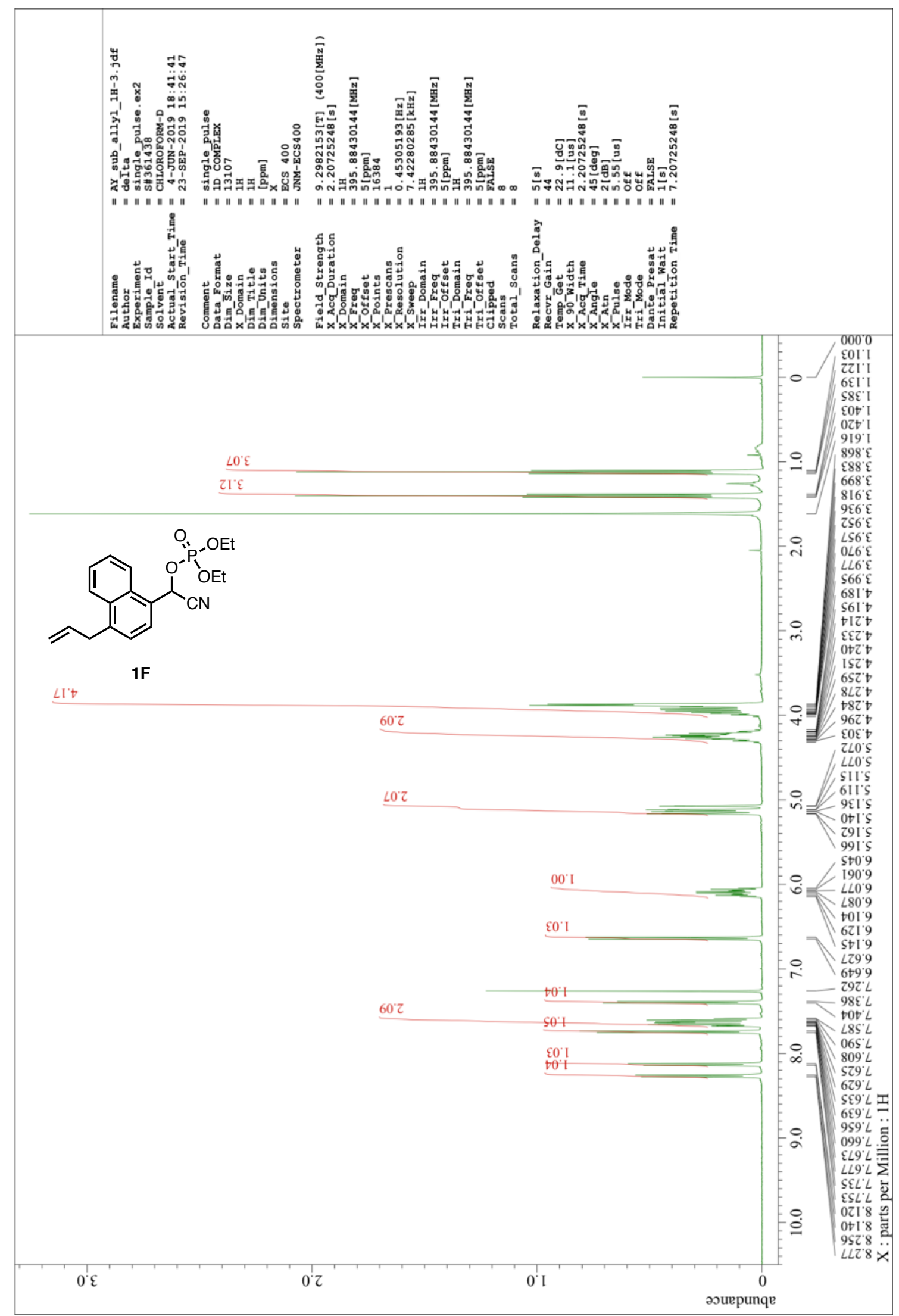


${ }^{13} \mathrm{C}$ NMR of $\mathbf{1 F}\left(101 \mathrm{MHz}, \mathrm{CDCl}_{3}\right)$

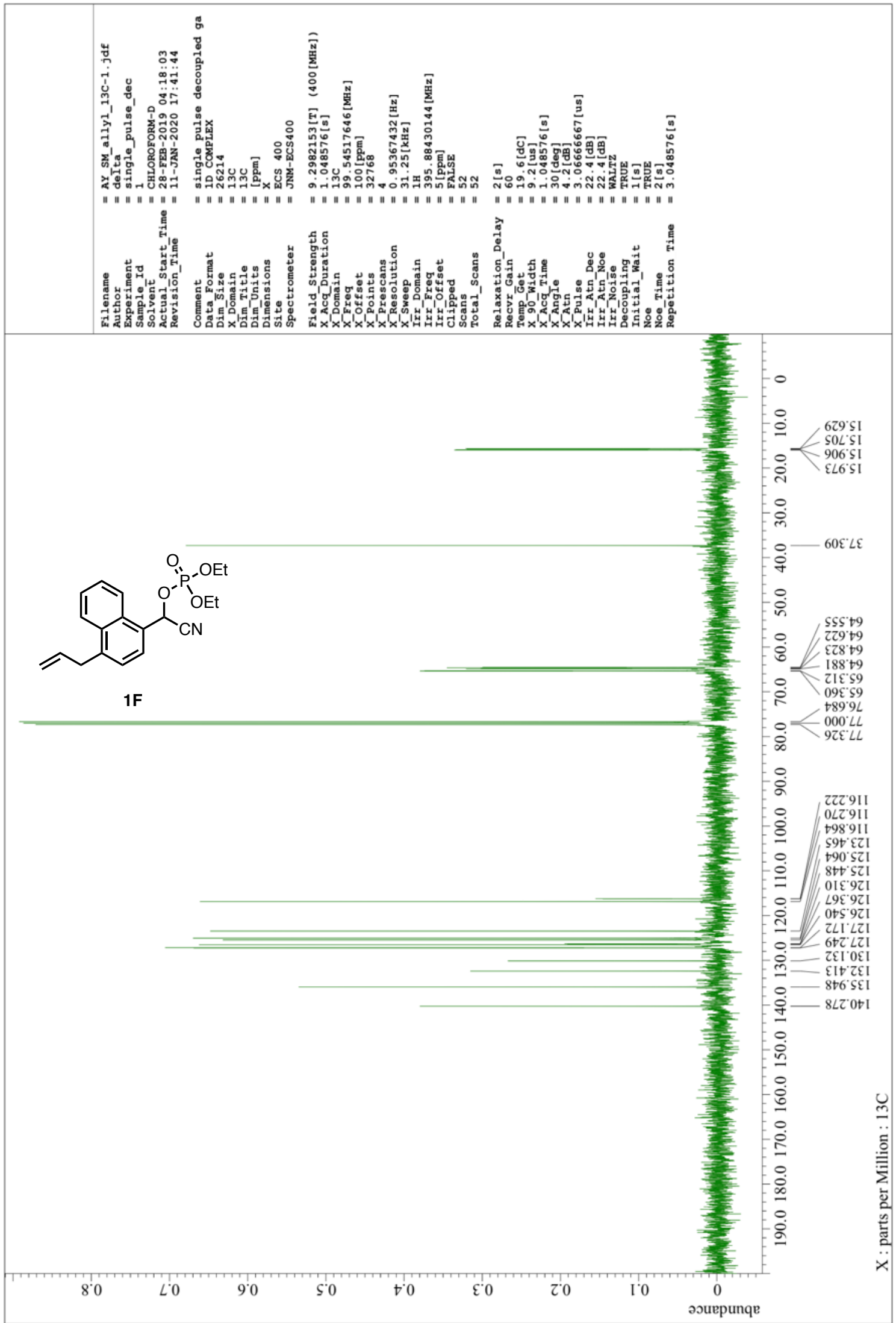


${ }^{31} \mathrm{P}$ NMR of 1F (162 MHz, $\left.\mathrm{CDCl}_{3}\right)$

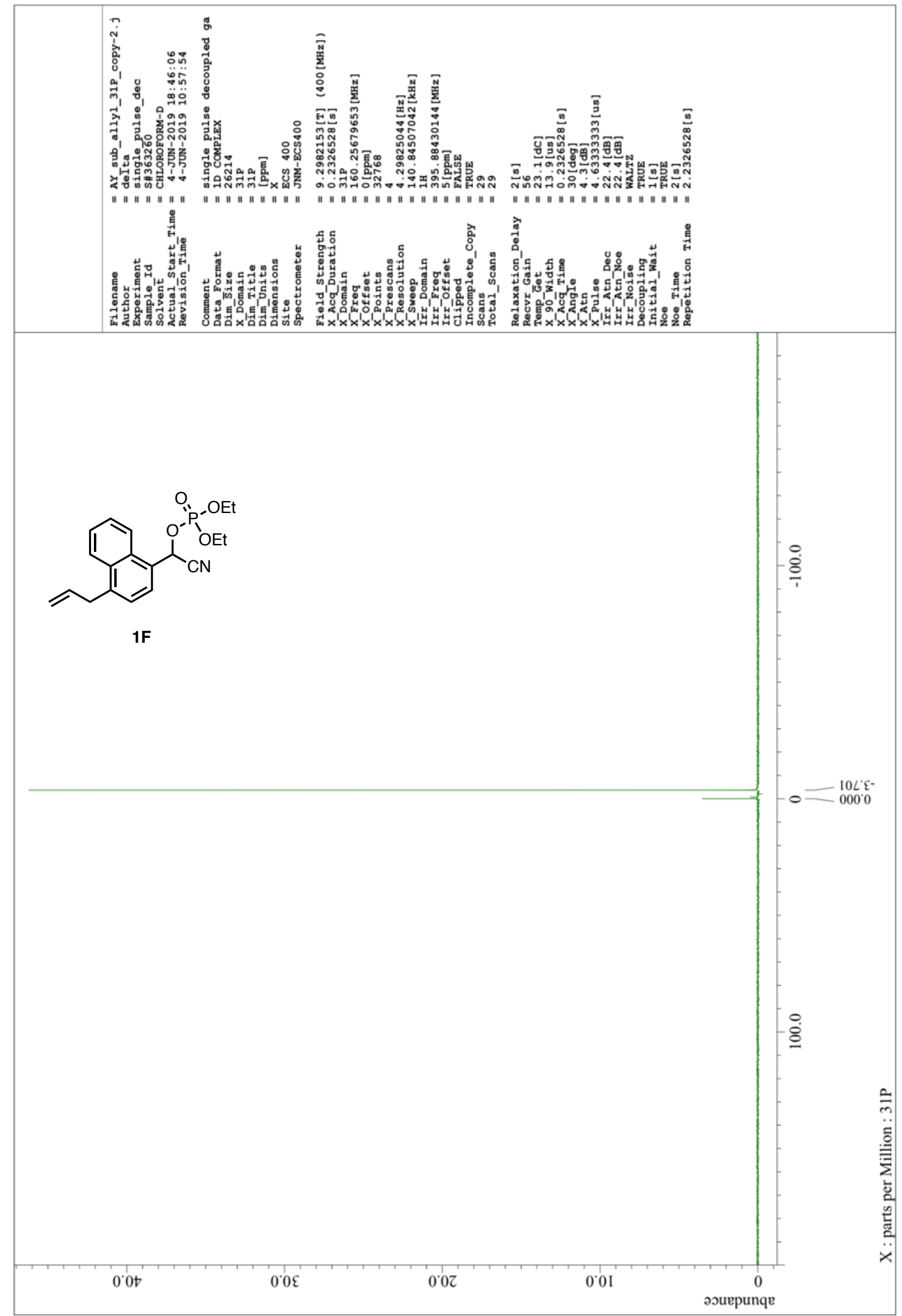


${ }^{1} \mathrm{H}$ NMR of $\mathbf{1 G}\left(400 \mathrm{MHz}, \mathrm{CDCl}_{3}\right)$

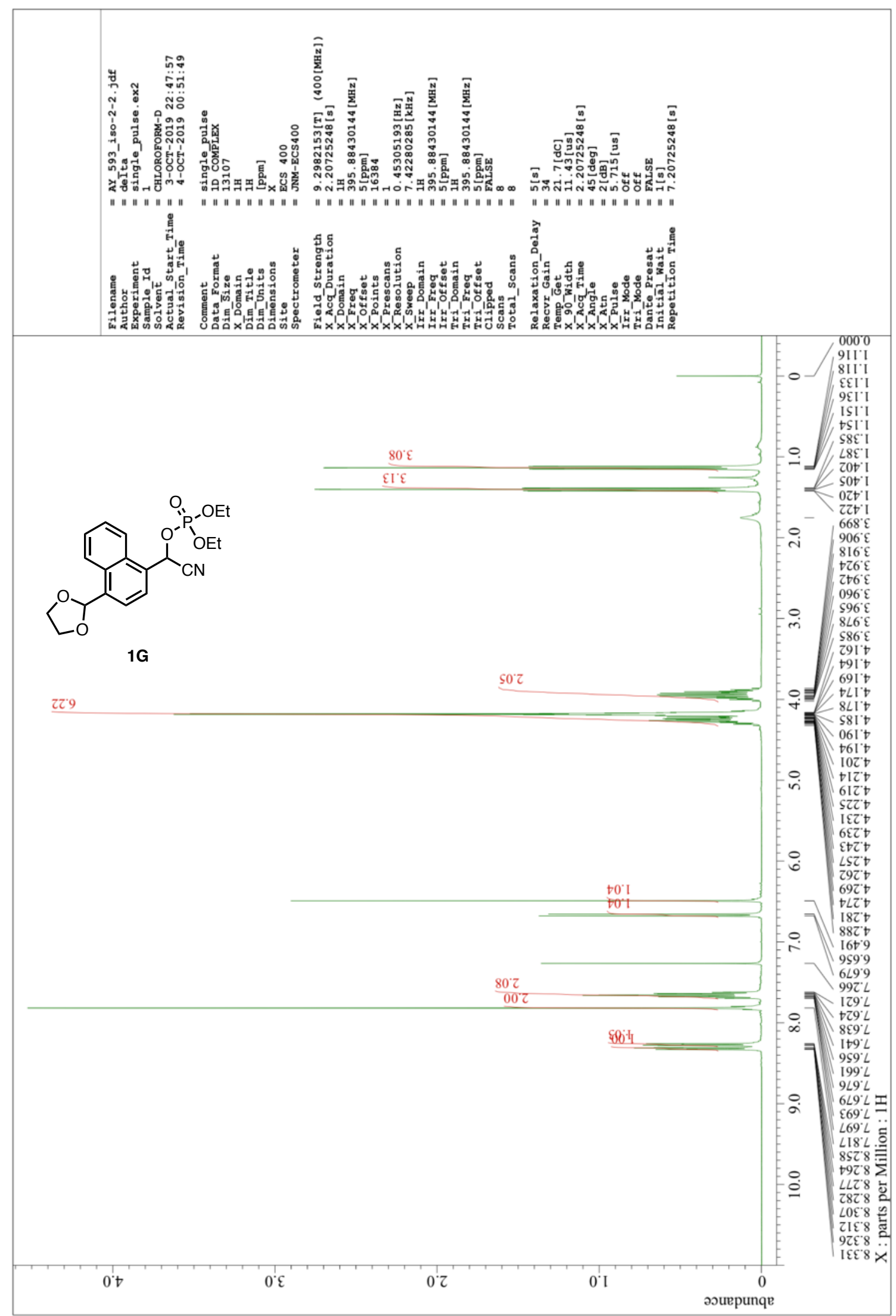


${ }^{13} \mathrm{C}$ NMR of $\mathbf{1 G}\left(101 \mathrm{MHz}, \mathrm{CDCl}_{3}\right)$

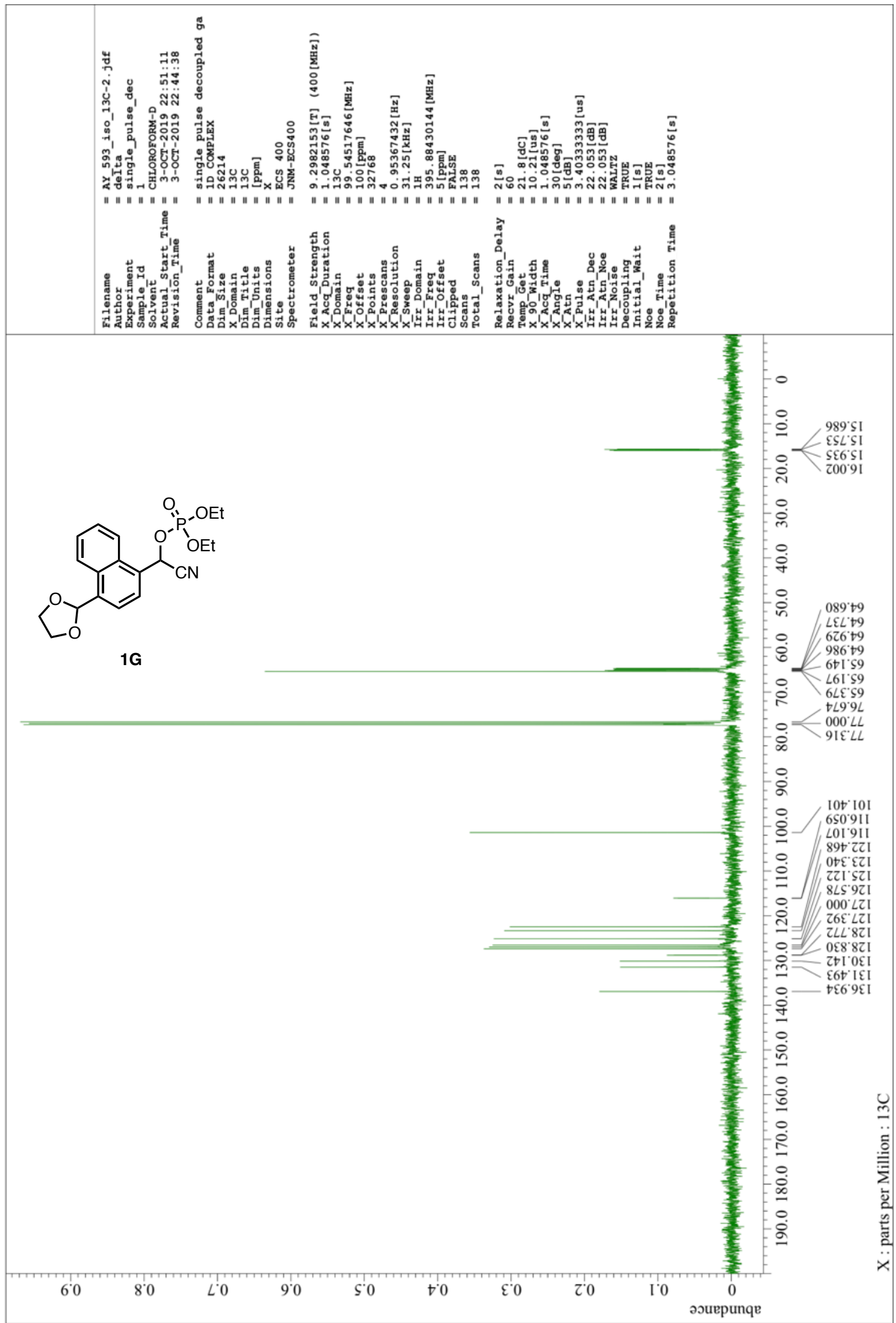


${ }^{31} \mathrm{P}$ NMR of $1 G\left(162 \mathrm{MHz}, \mathrm{CDCl}_{3}\right)$

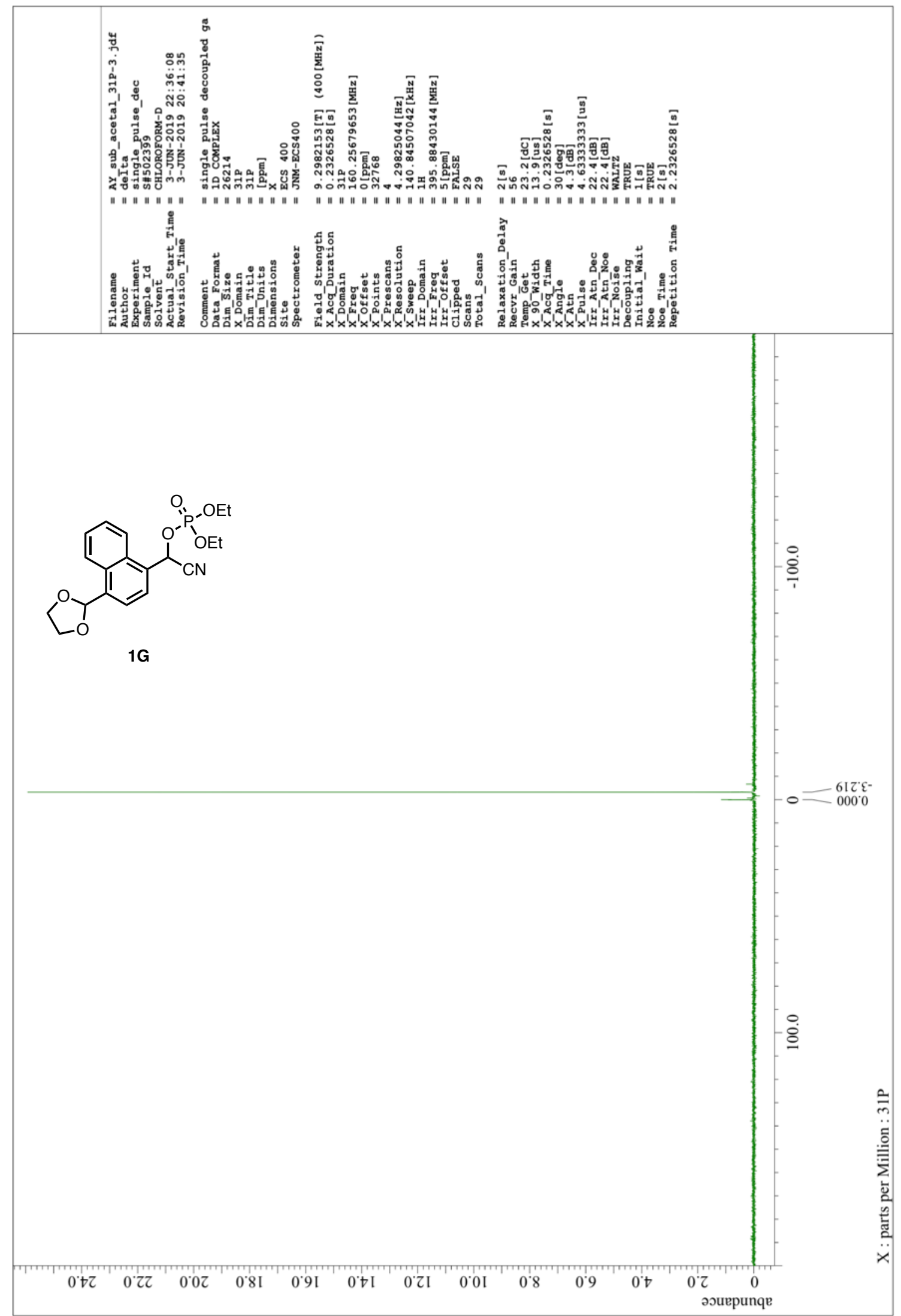


${ }^{1} \mathrm{H}$ NMR of $\mathbf{1 H}\left(400 \mathrm{MHz}, \mathrm{CDCl}_{3}\right)$

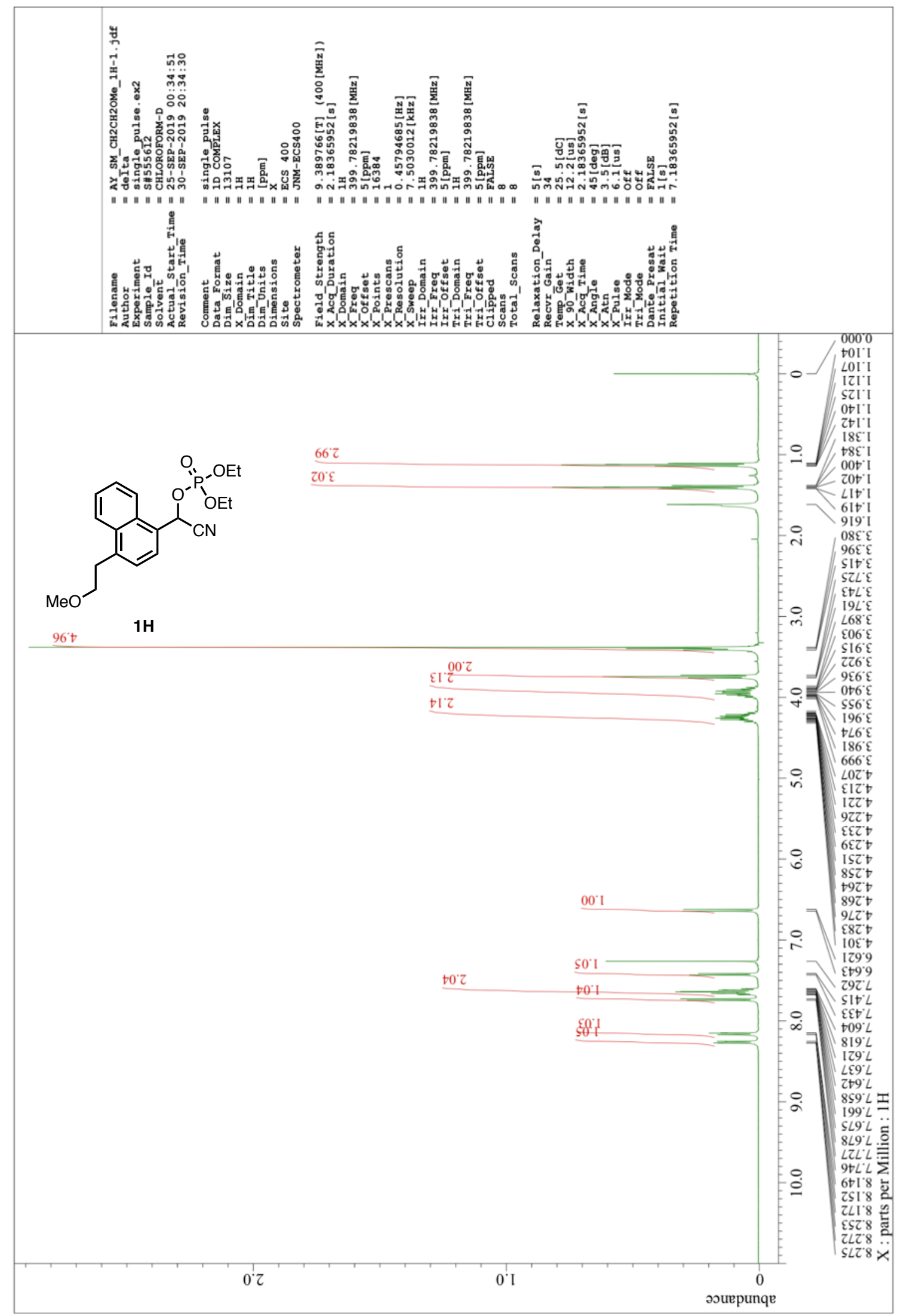


${ }^{13} \mathrm{C}$ NMR of $\mathbf{1 H}\left(101 \mathrm{MHz}, \mathrm{CDCl}_{3}\right)$

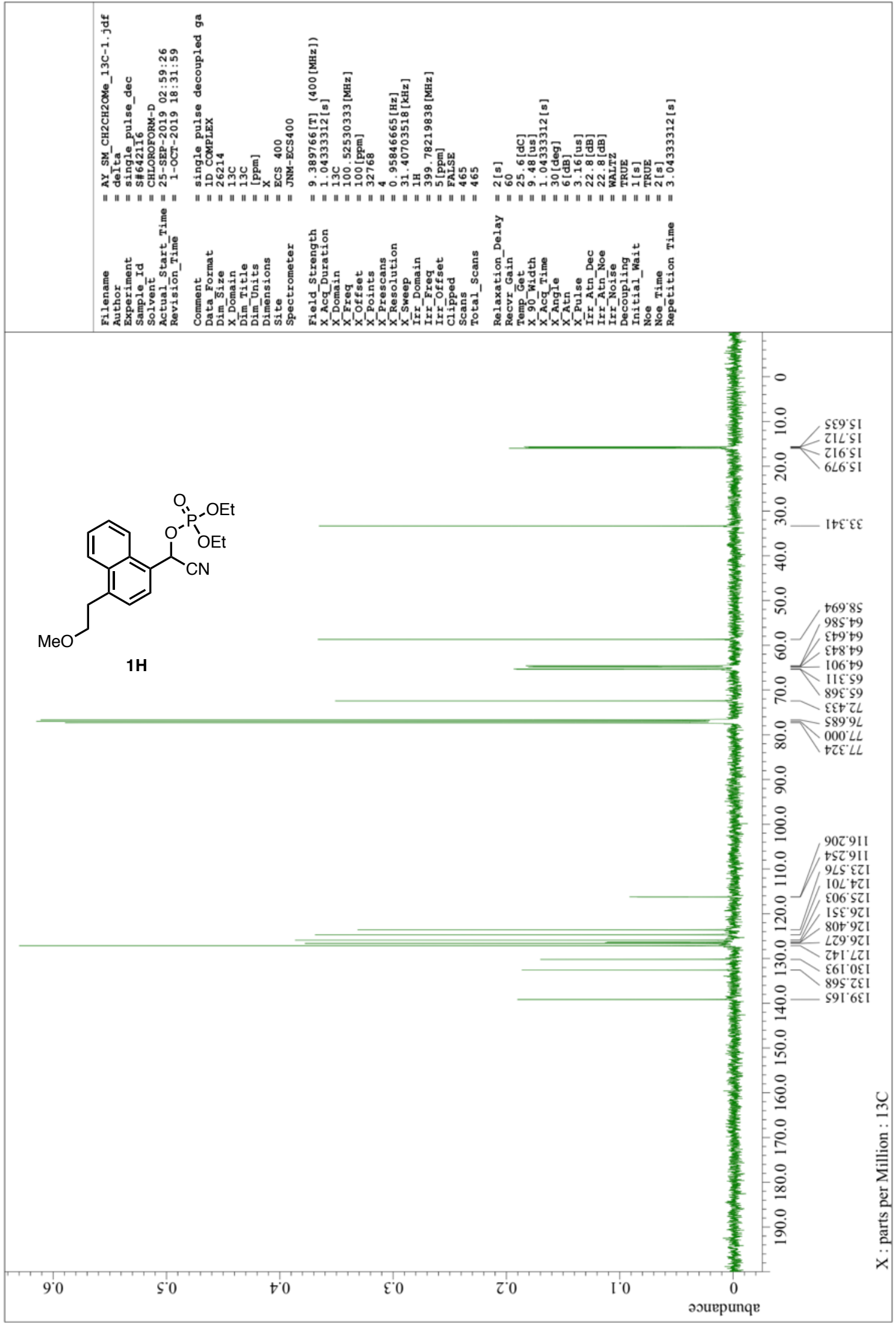


${ }^{31} \mathrm{P}$ NMR of $\mathbf{1 H}\left(162 \mathrm{MHz}, \mathrm{CDCl}_{3}\right)$

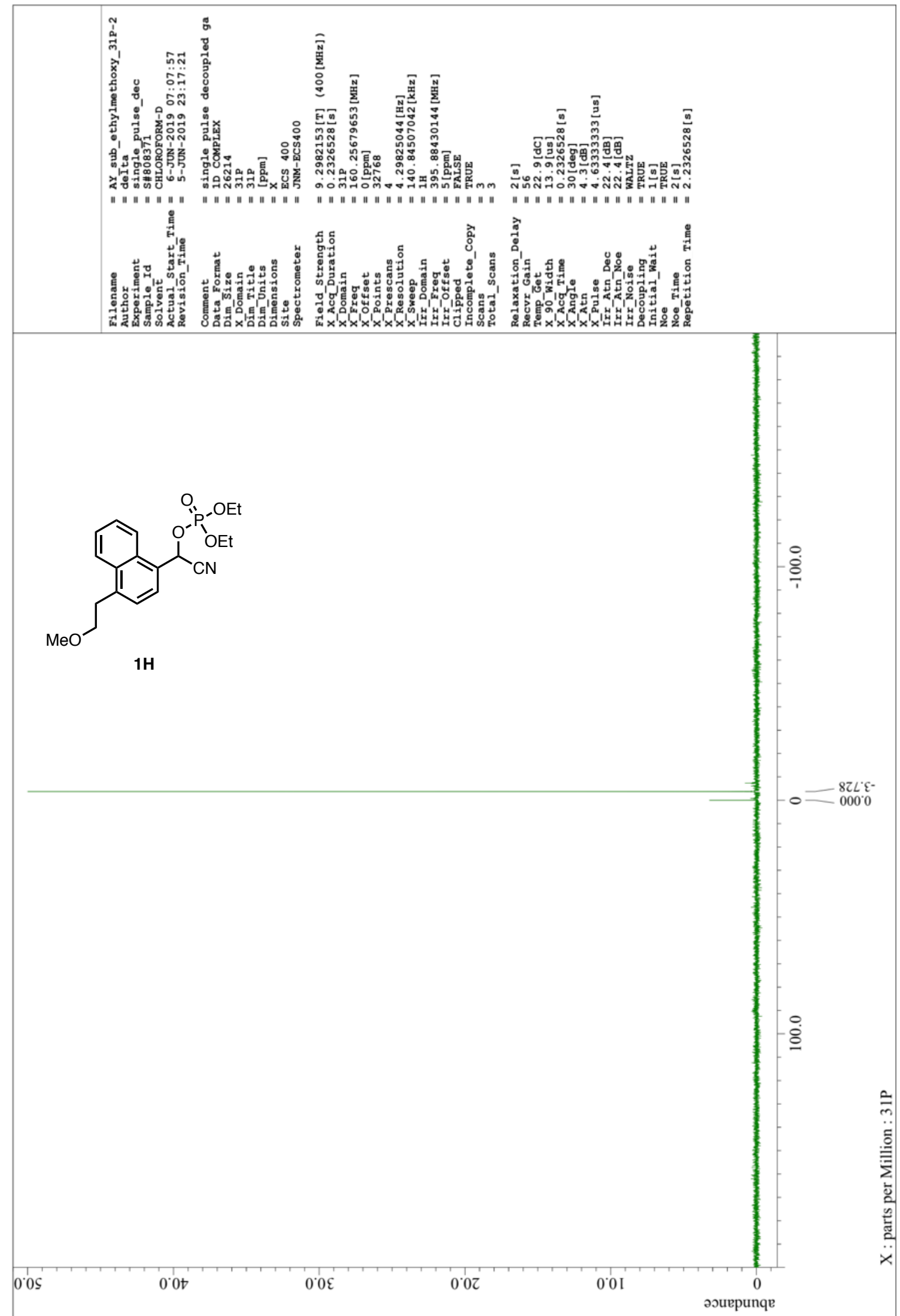


${ }^{1} \mathrm{H}$ NMR of 1 I $\left(400 \mathrm{MHz}, \mathrm{CDCl}_{3}\right)$

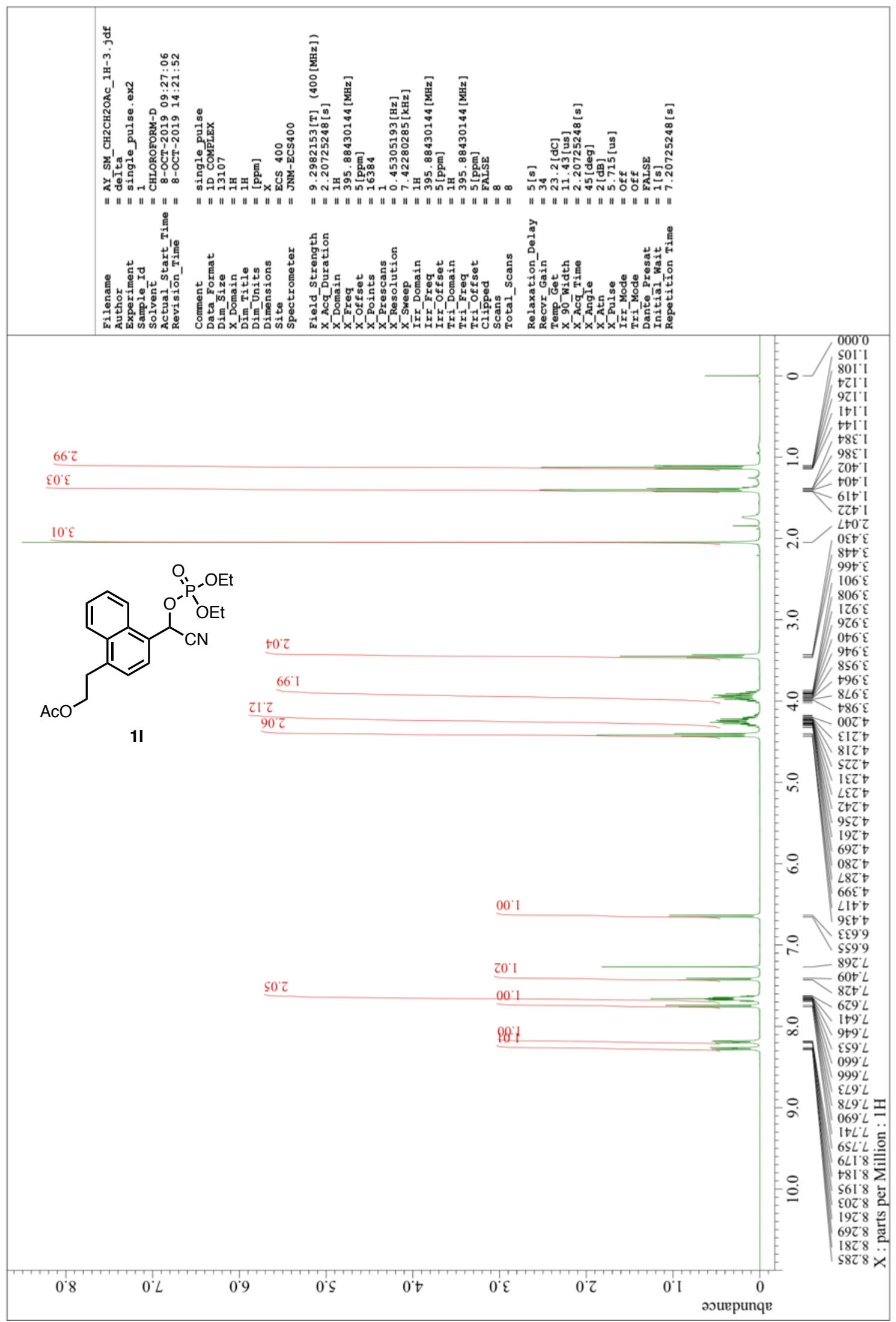


${ }^{13} \mathrm{C}$ NMR of $1 \mathbf{I}\left(101 \mathrm{MHz}, \mathrm{CDCl}_{3}\right)$

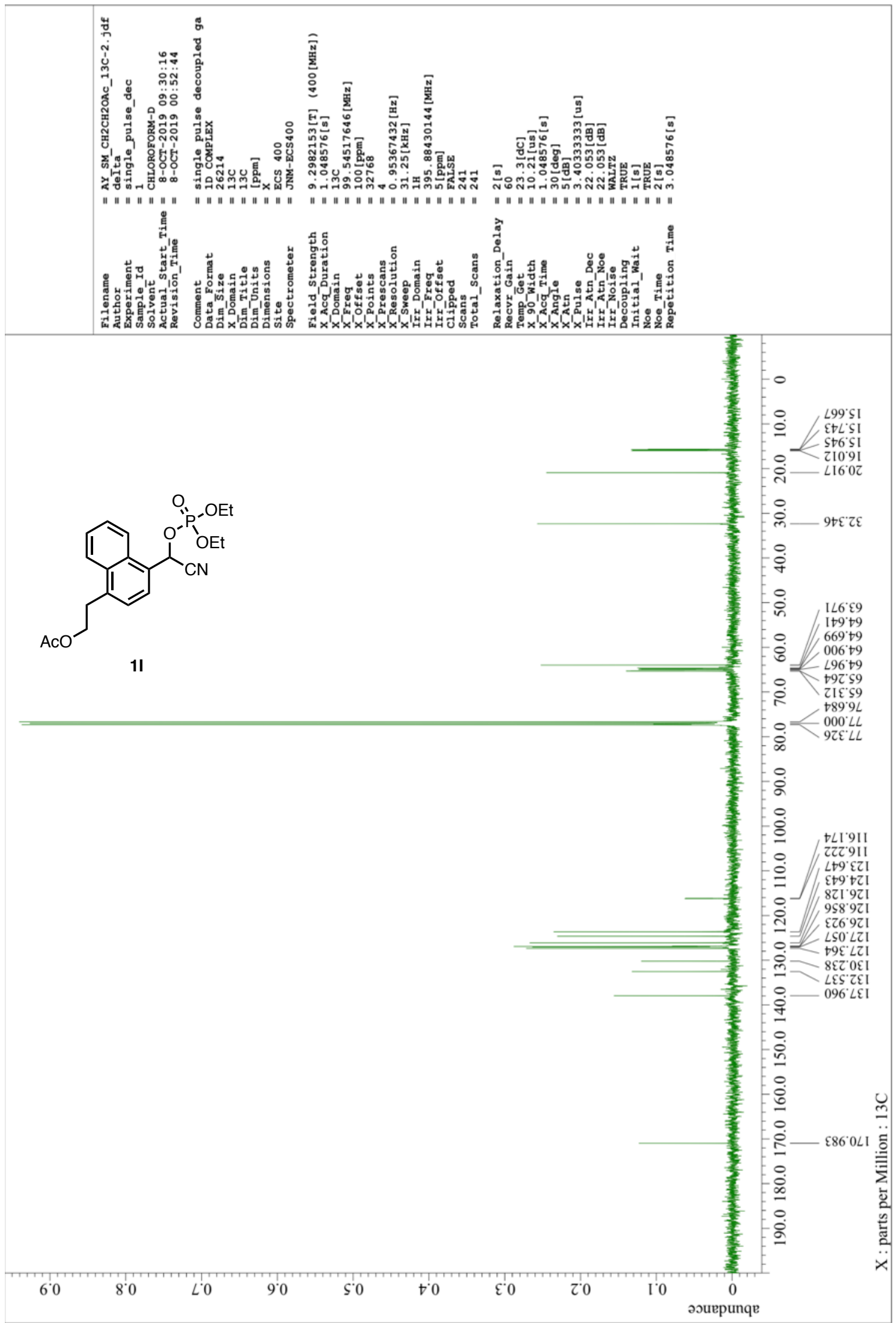


${ }^{31} \mathrm{P}$ NMR of 1 I $\left(162 \mathrm{MHz}, \mathrm{CDCl}_{3}\right)$

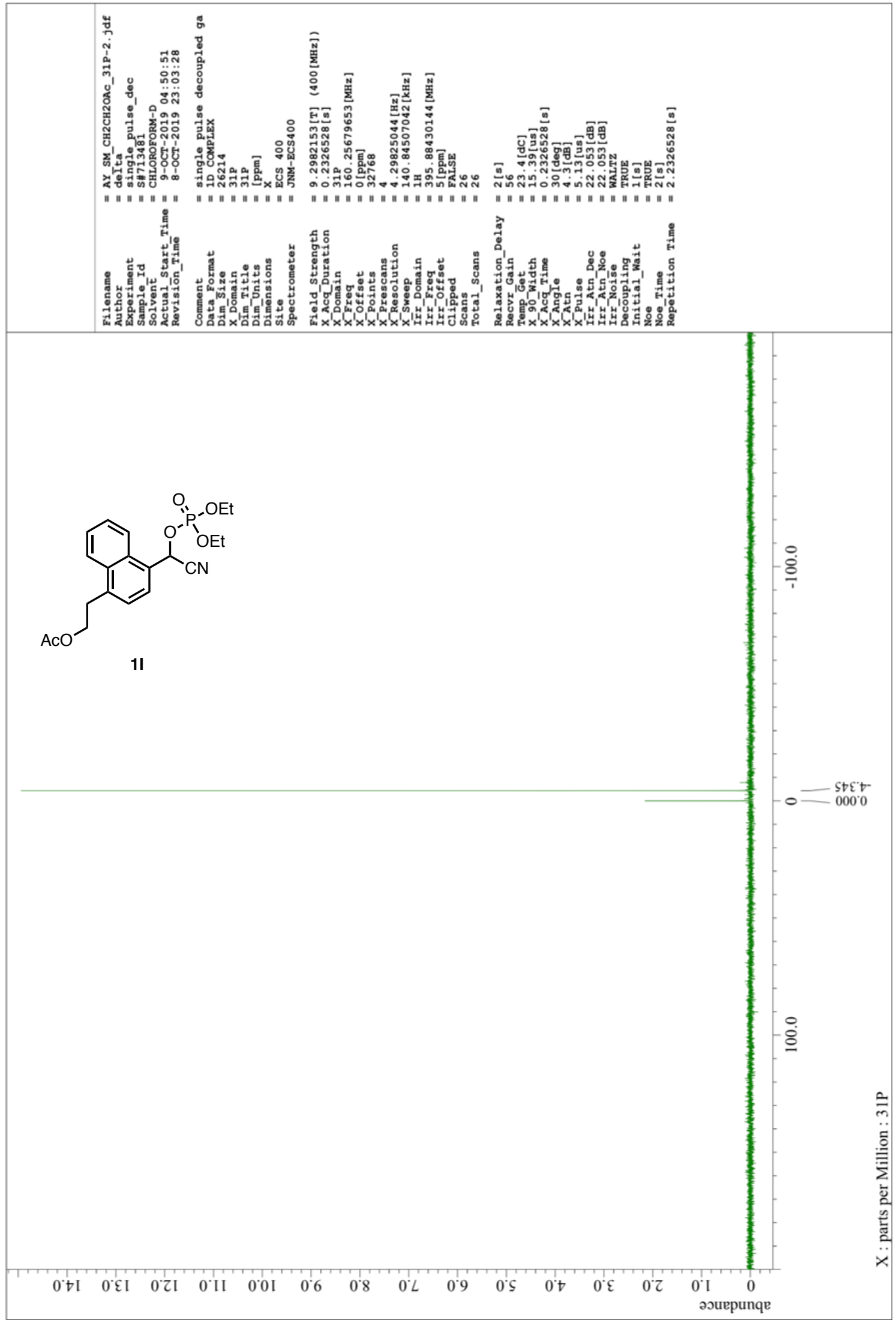


${ }^{1} \mathrm{H} \mathrm{NMR}$ of $\mathbf{1 J}\left(400 \mathrm{MHz}, \mathrm{CDCl}_{3}\right)$

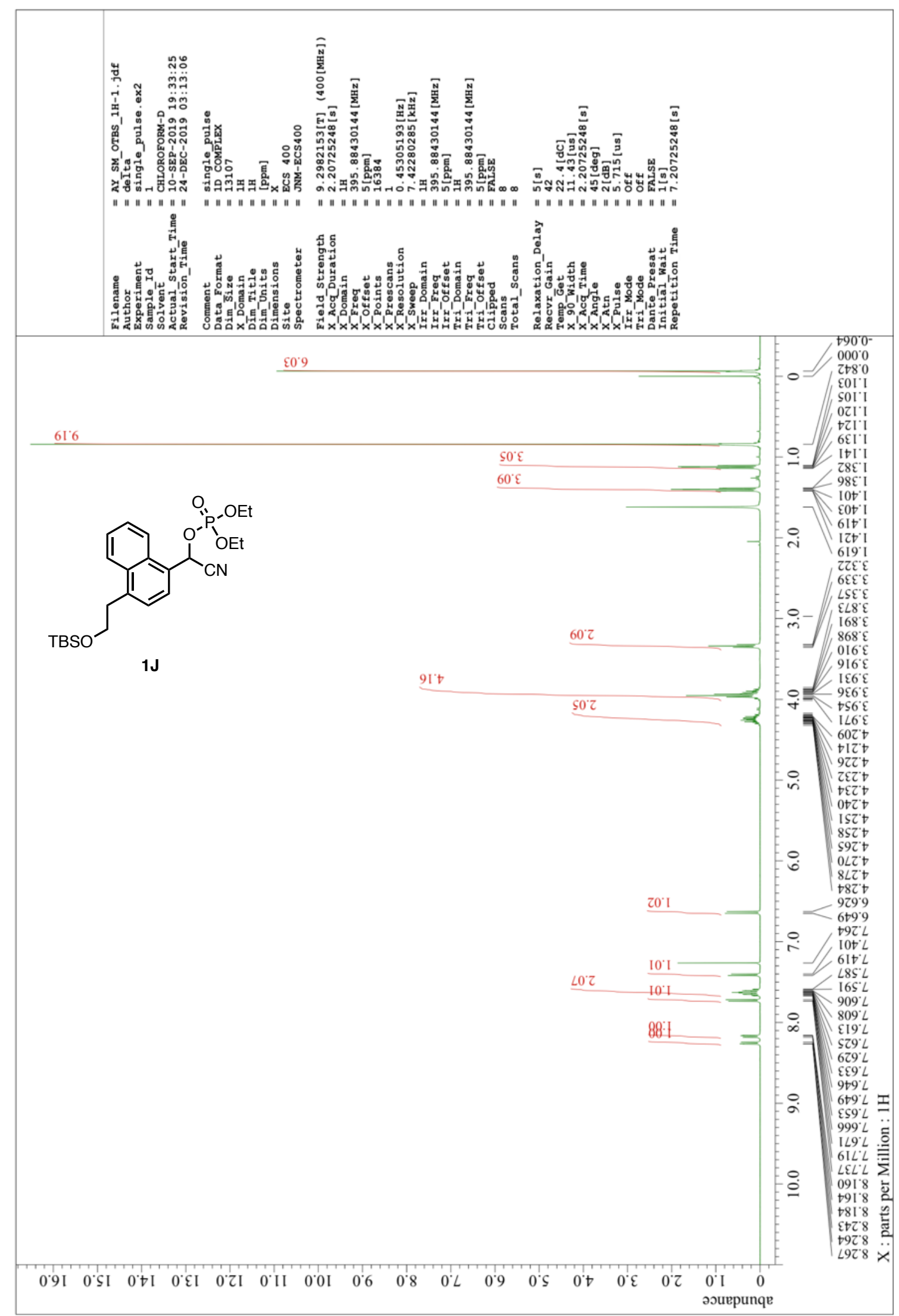


${ }^{13} \mathrm{C}$ NMR of $\mathbf{1 J}\left(101 \mathrm{MHz}, \mathrm{CDCl}_{3}\right)$

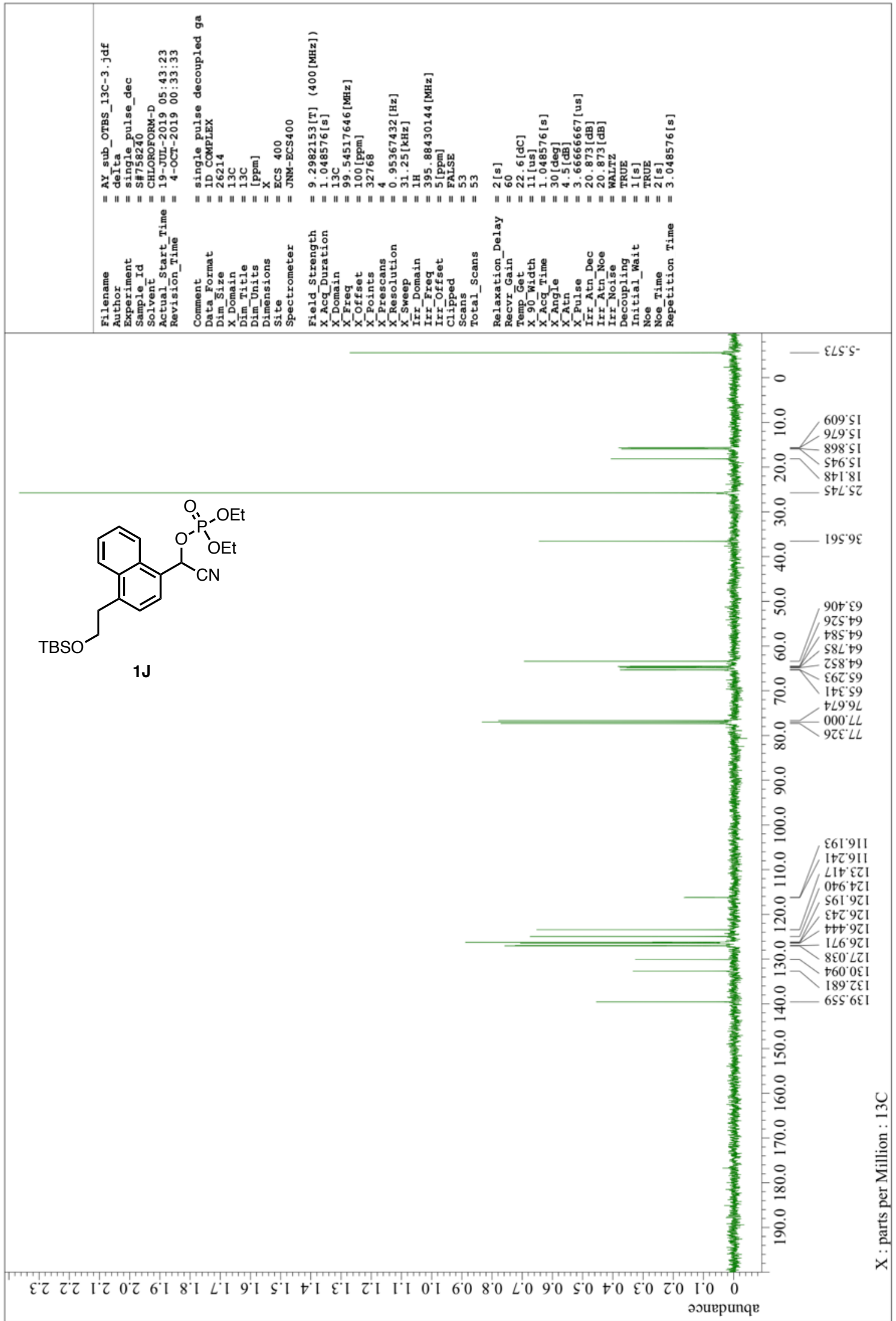




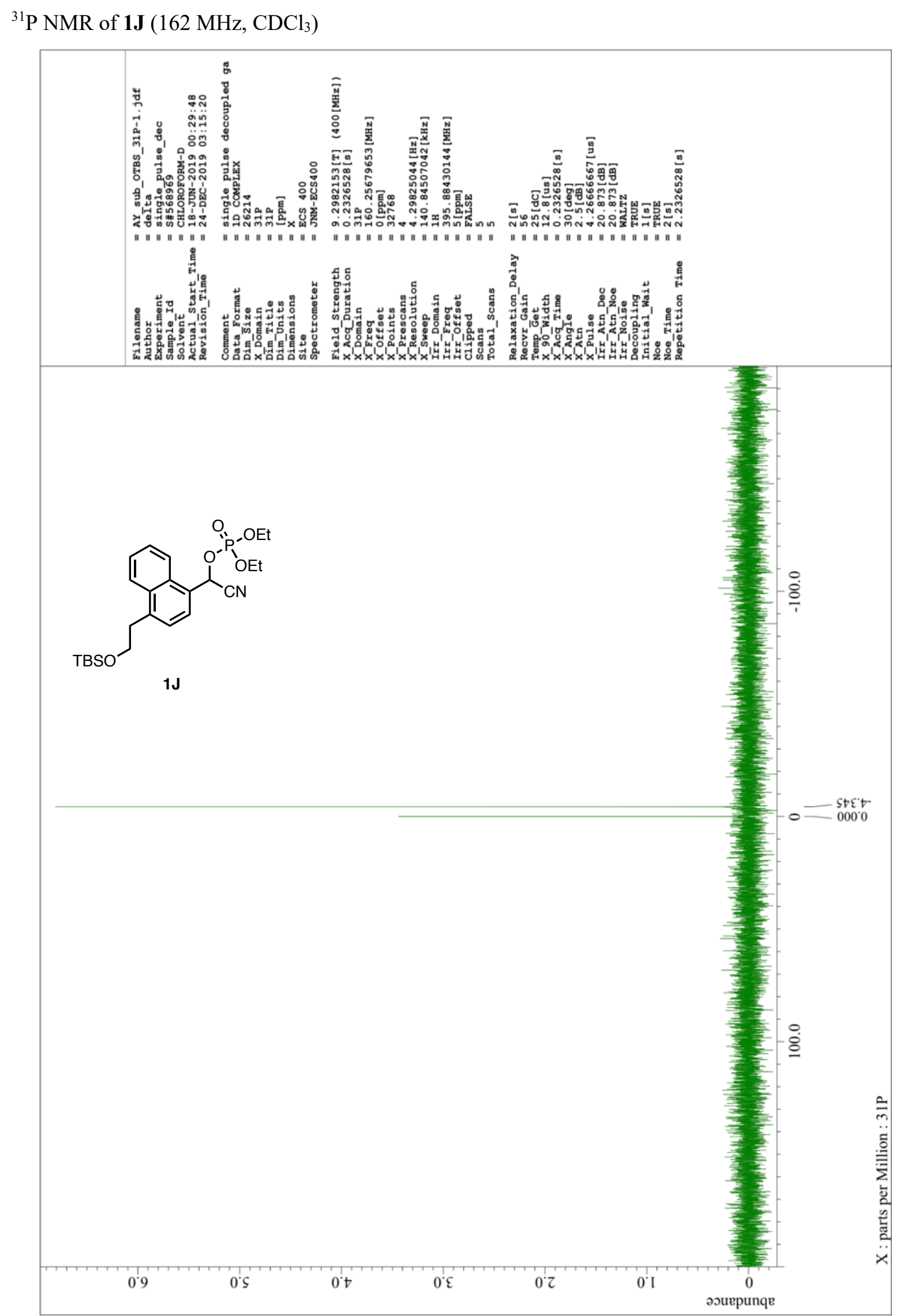


${ }^{1} \mathrm{H}$ NMR of $\mathbf{3 A}\left(400 \mathrm{MHz}, \mathrm{CDCl}_{3}\right)$

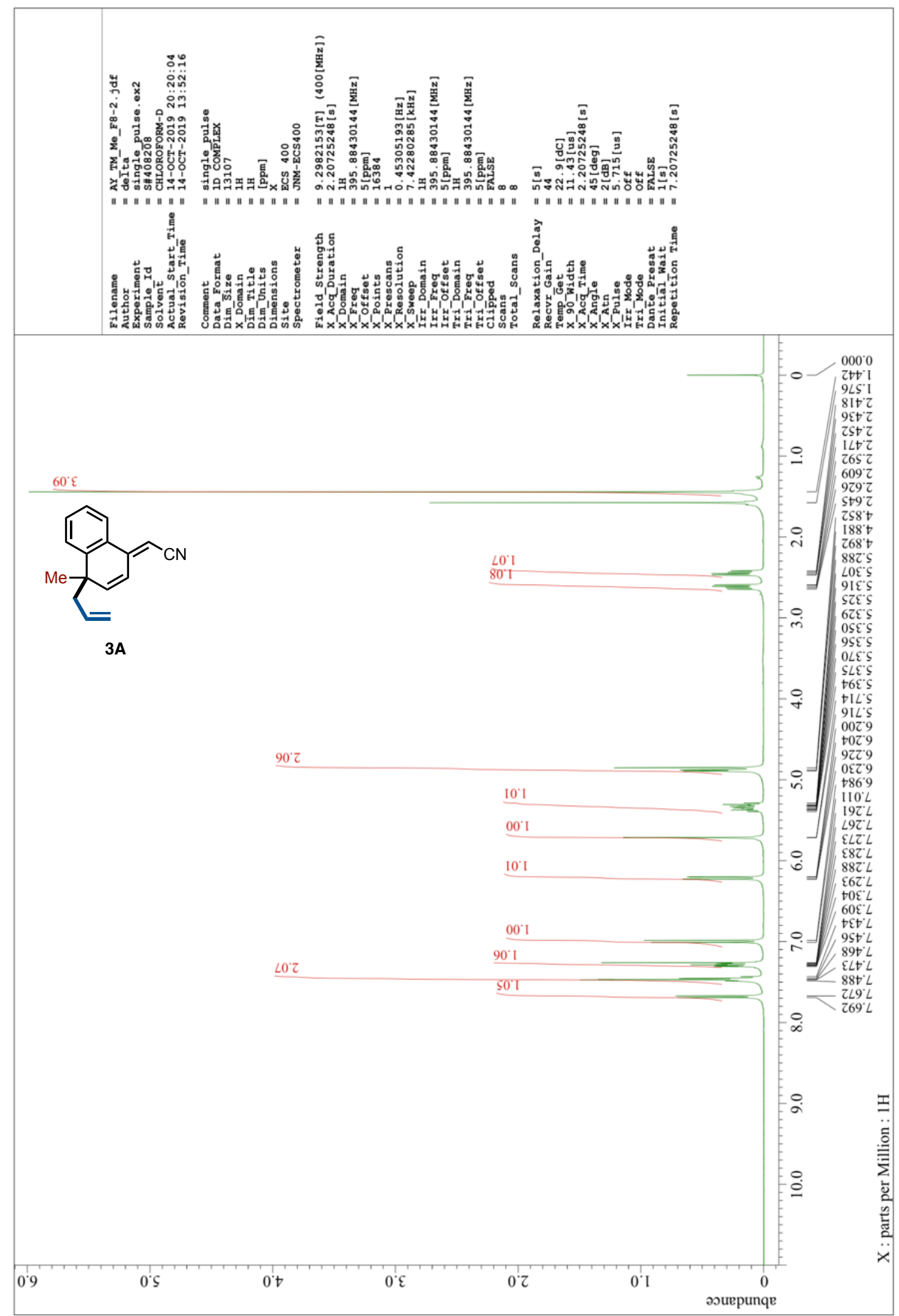


${ }^{13} \mathrm{C}$ NMR of $\mathbf{3 A}\left(101 \mathrm{MHz}, \mathrm{CDCl}_{3}\right)$

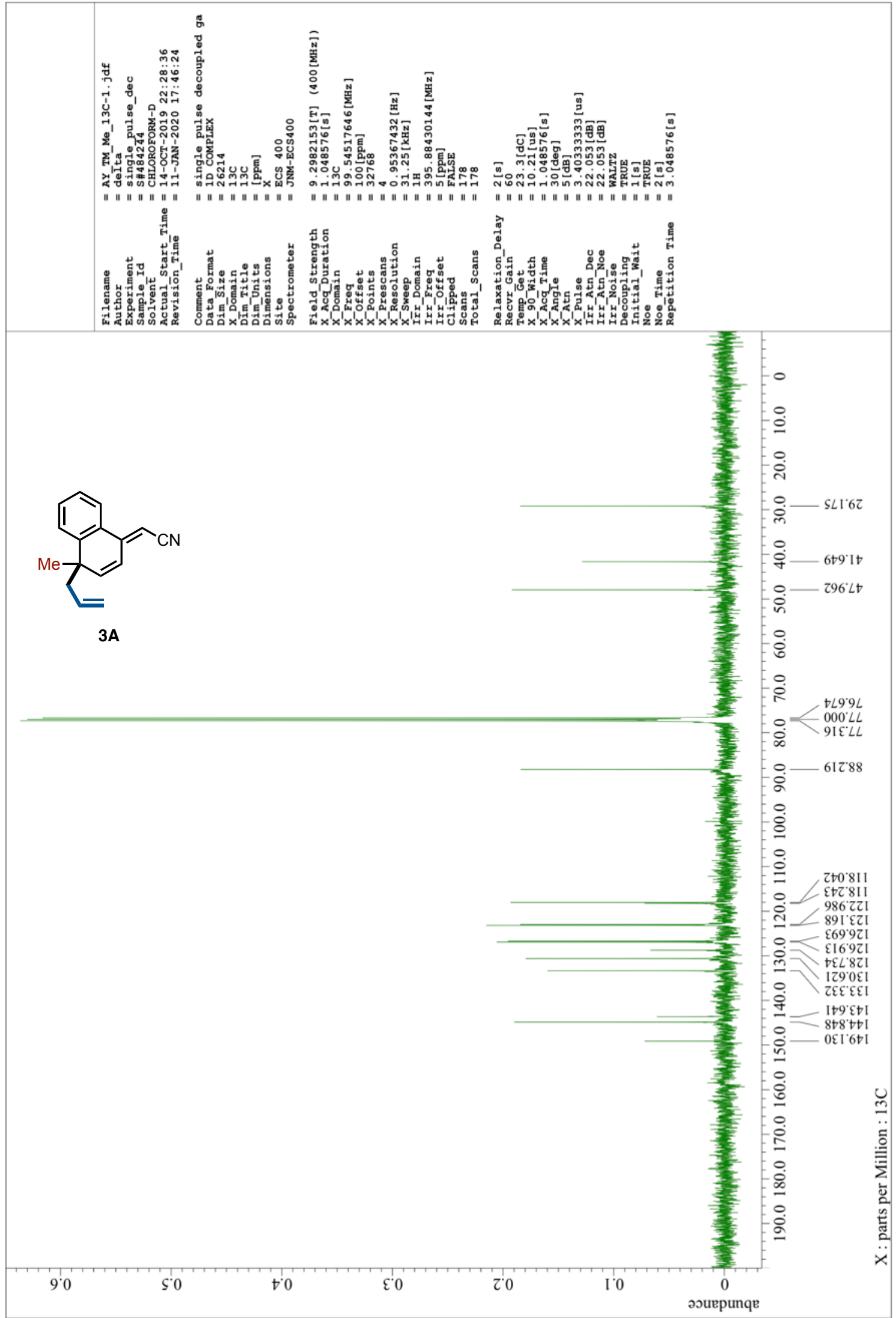


${ }^{1} \mathrm{H}$ NMR of 3B $\left(400 \mathrm{MHz}, \mathrm{CDCl}_{3}\right)$

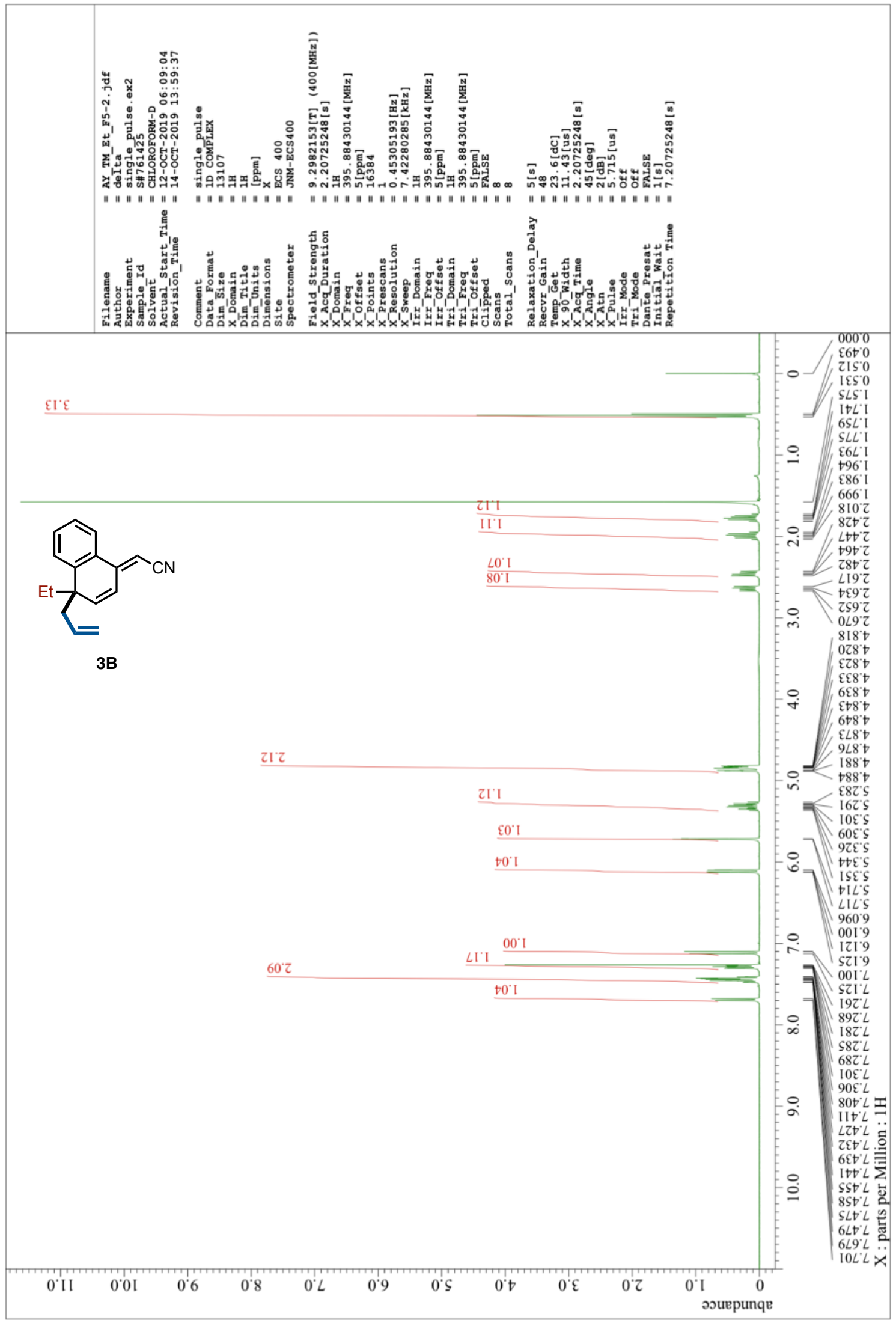


${ }^{13} \mathrm{C}$ NMR of 3B $\left(101 \mathrm{MHz}, \mathrm{CDCl}_{3}\right)$

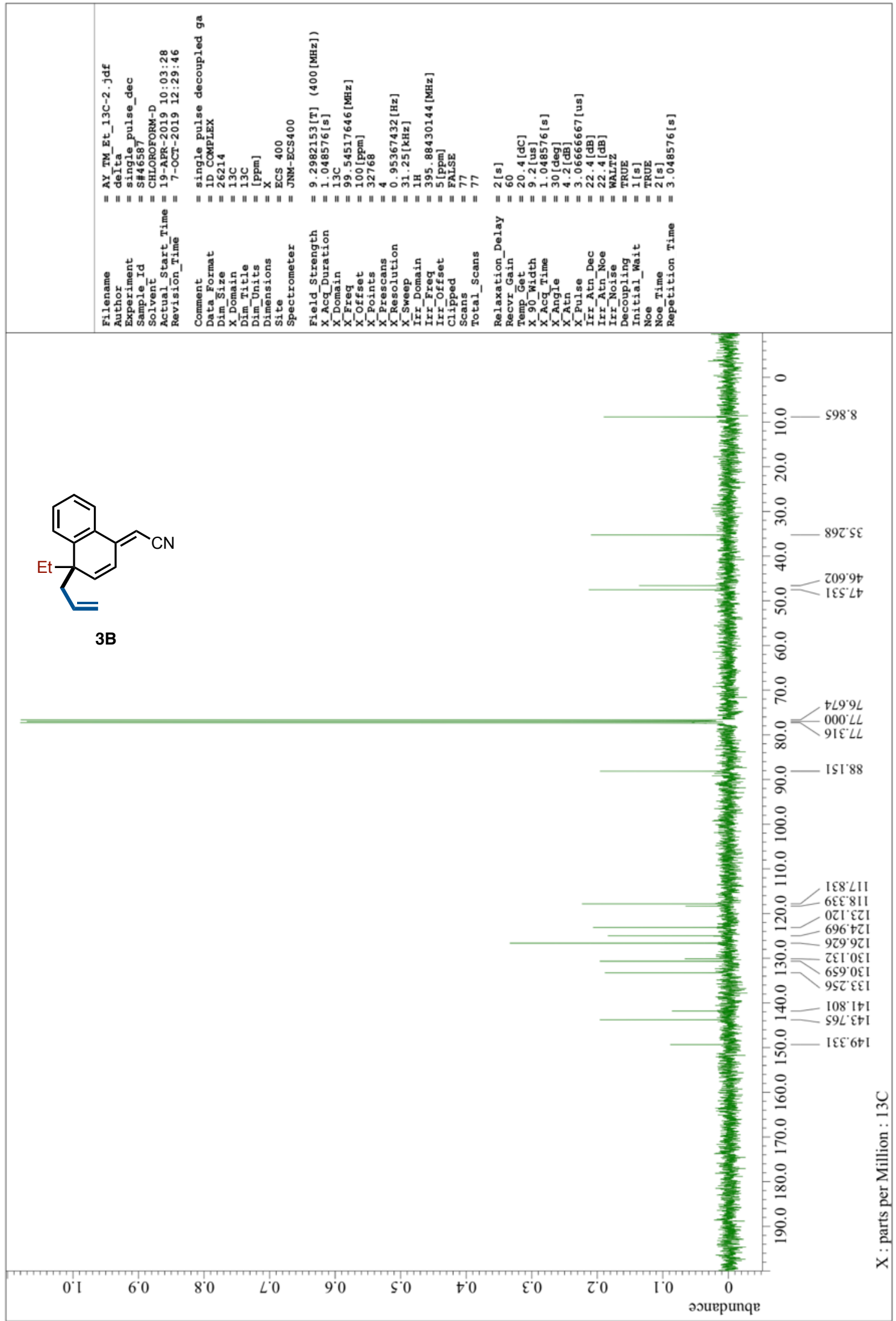


${ }^{1} \mathrm{H}$ NMR of $3 \mathrm{C}\left(400 \mathrm{MHz}, \mathrm{CDCl}_{3}\right)$

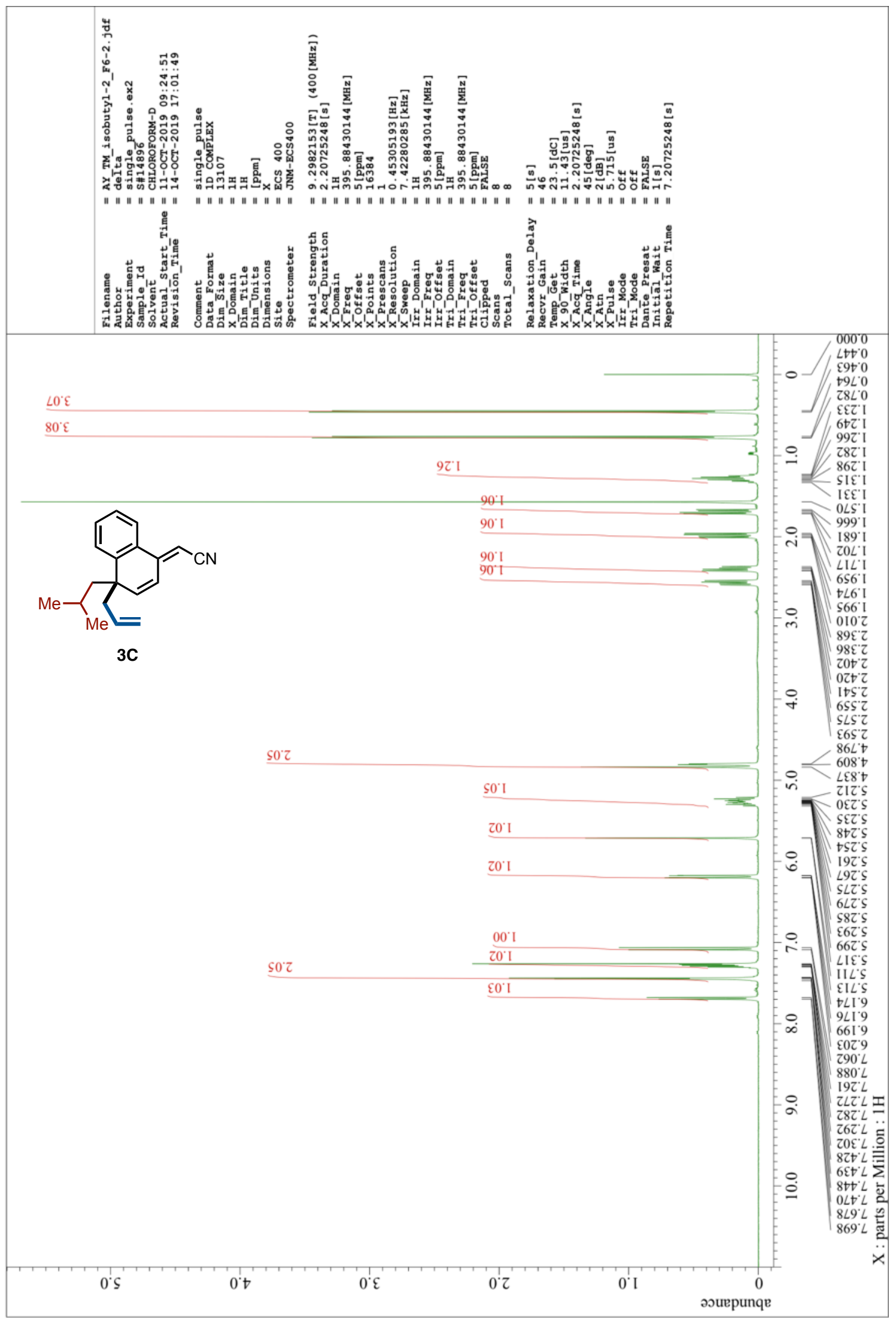


${ }^{13} \mathrm{C}$ NMR of $3 \mathrm{C}\left(101 \mathrm{MHz}, \mathrm{CDCl}_{3}\right)$

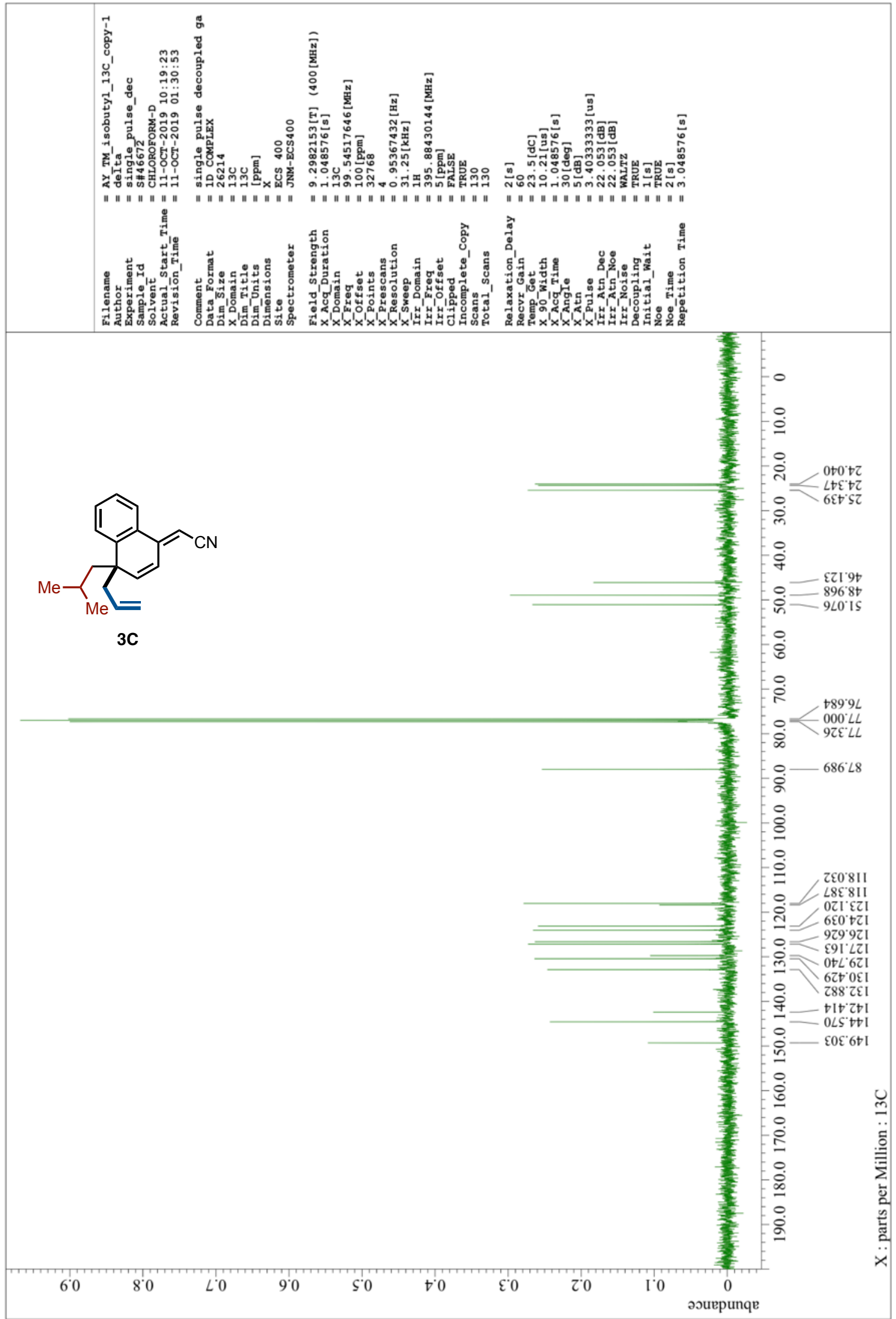


${ }^{1} \mathrm{H}$ NMR of 3D $\left(400 \mathrm{MHz}, \mathrm{CDCl}_{3}\right)$

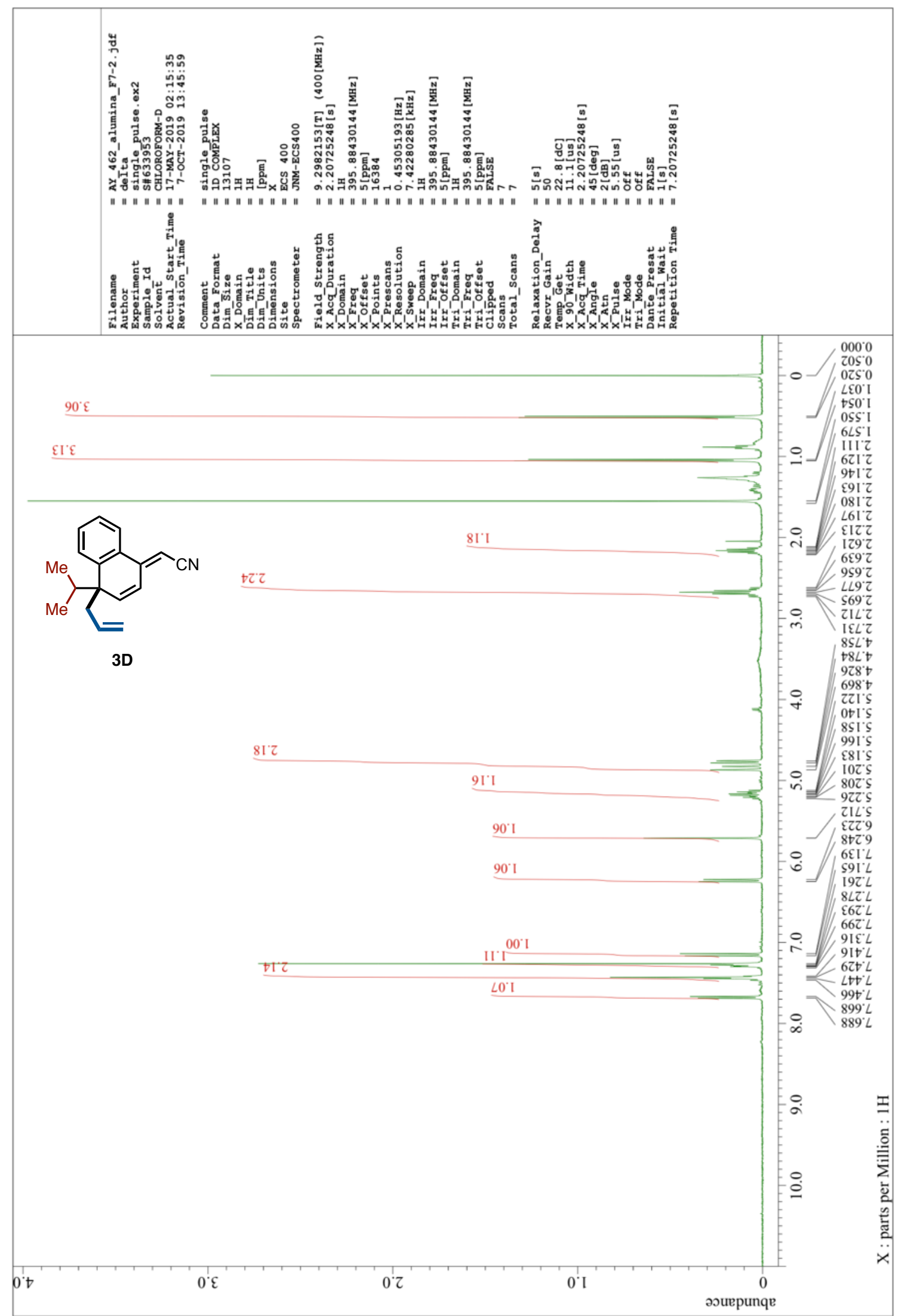


${ }^{13} \mathrm{C}$ NMR of 3D $\left(101 \mathrm{MHz}, \mathrm{CDCl}_{3}\right)$

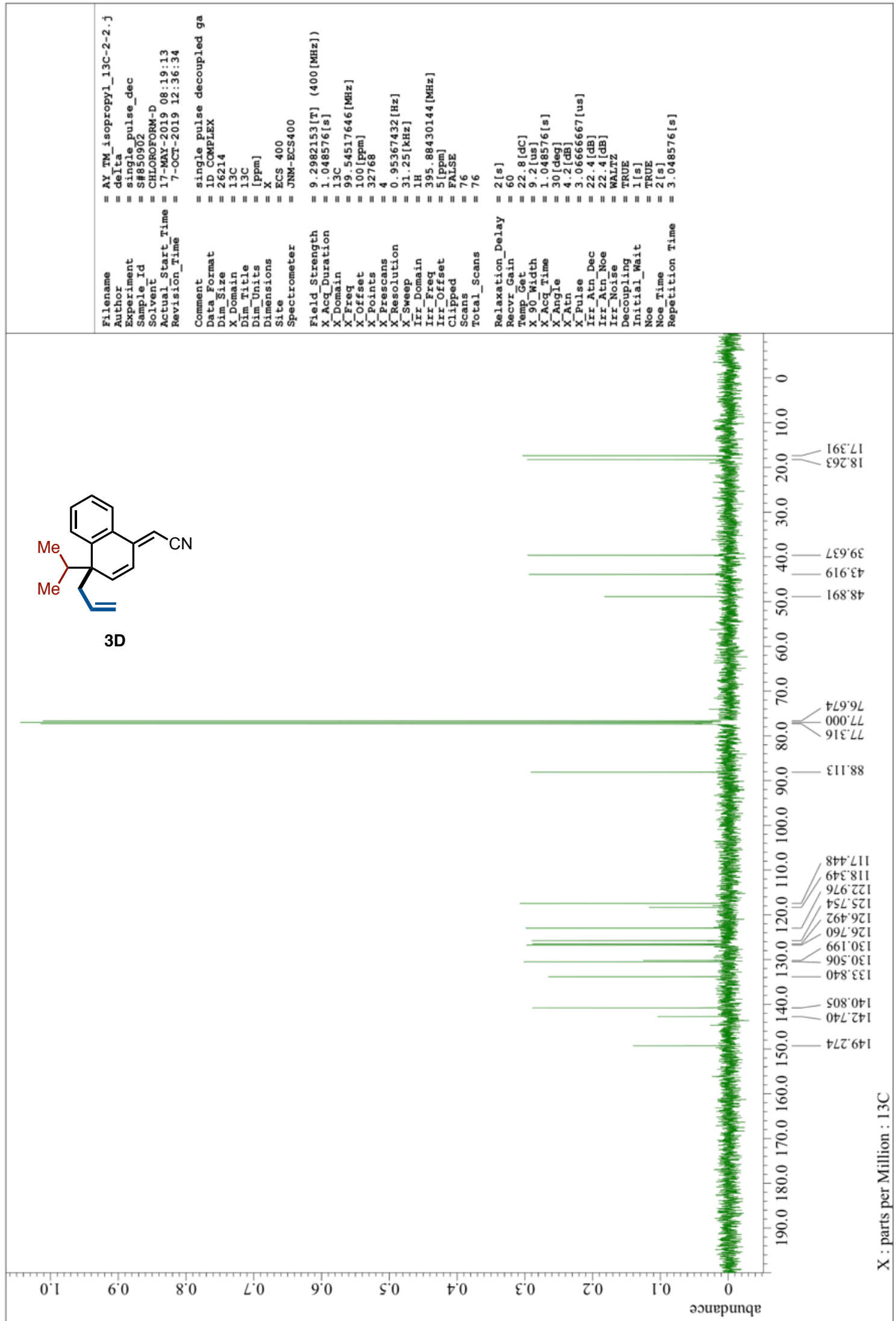


${ }^{1} \mathrm{H}$ NMR of $\mathbf{3 E}\left(400 \mathrm{MHz}, \mathrm{CDCl}_{3}\right)$

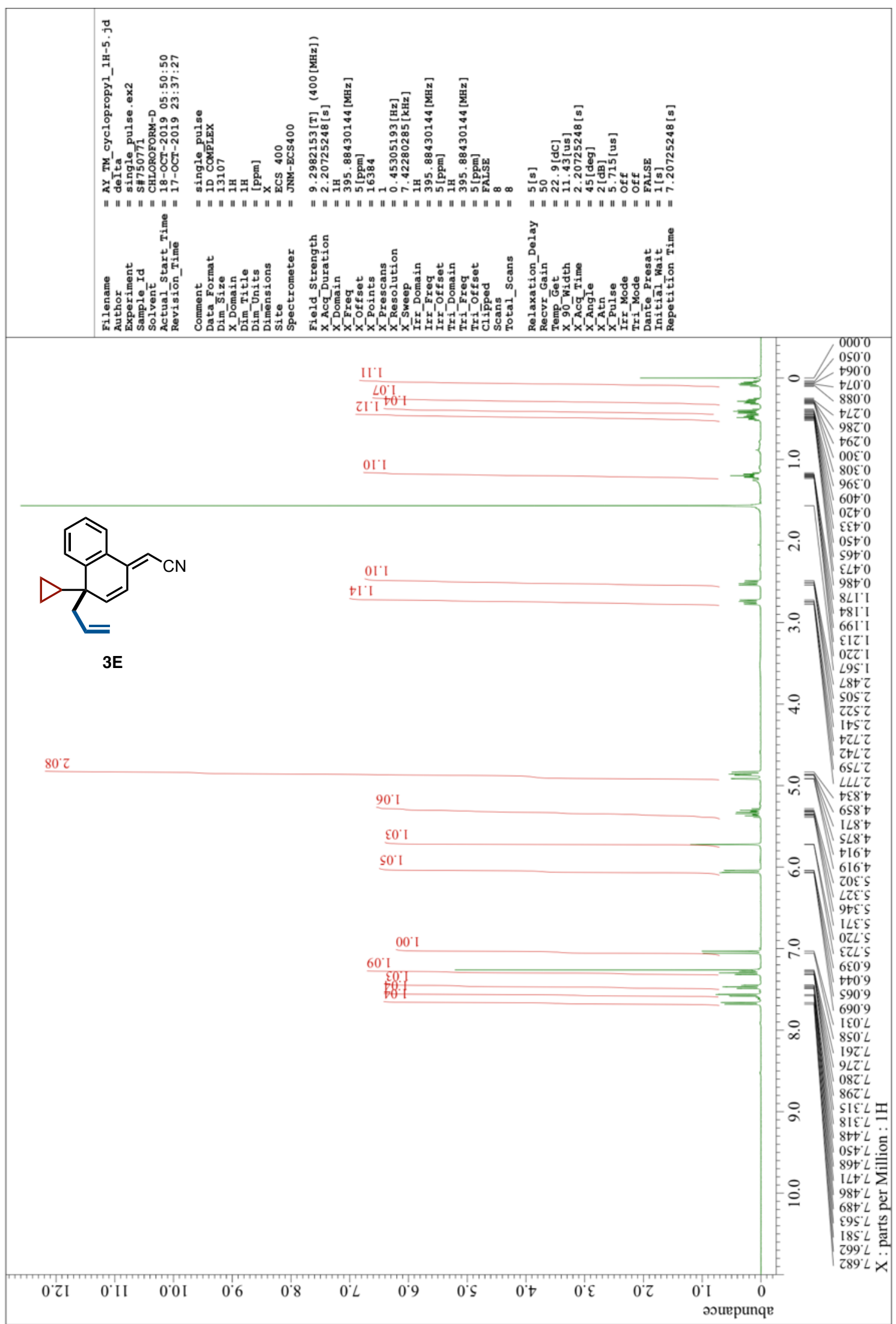


${ }^{13} \mathrm{C}$ NMR of 3E $\left(101 \mathrm{MHz}, \mathrm{CDCl}_{3}\right)$

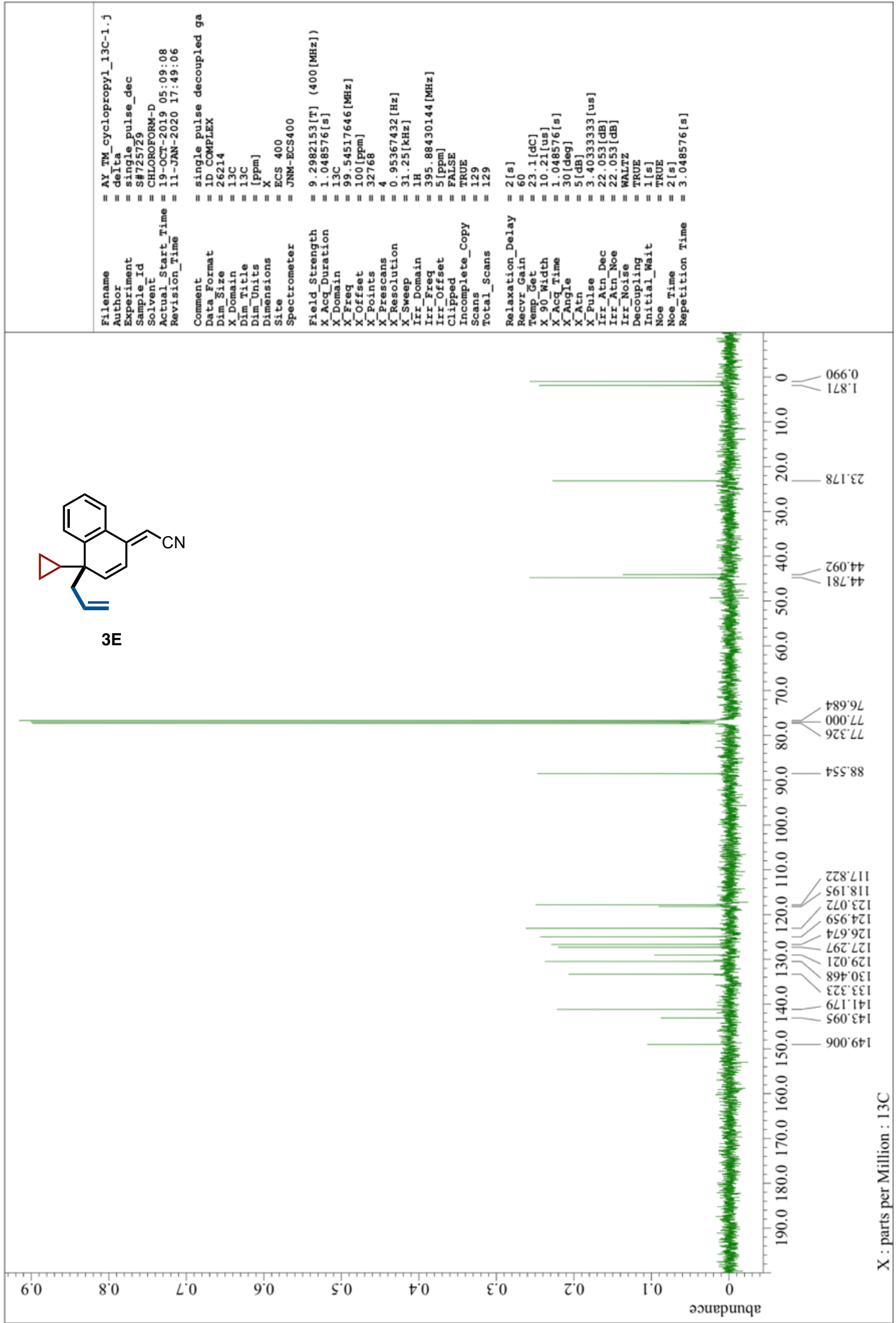


${ }^{1} \mathrm{H}$ NMR of $\mathbf{3 F}\left(400 \mathrm{MHz}, \mathrm{CDCl}_{3}\right)$

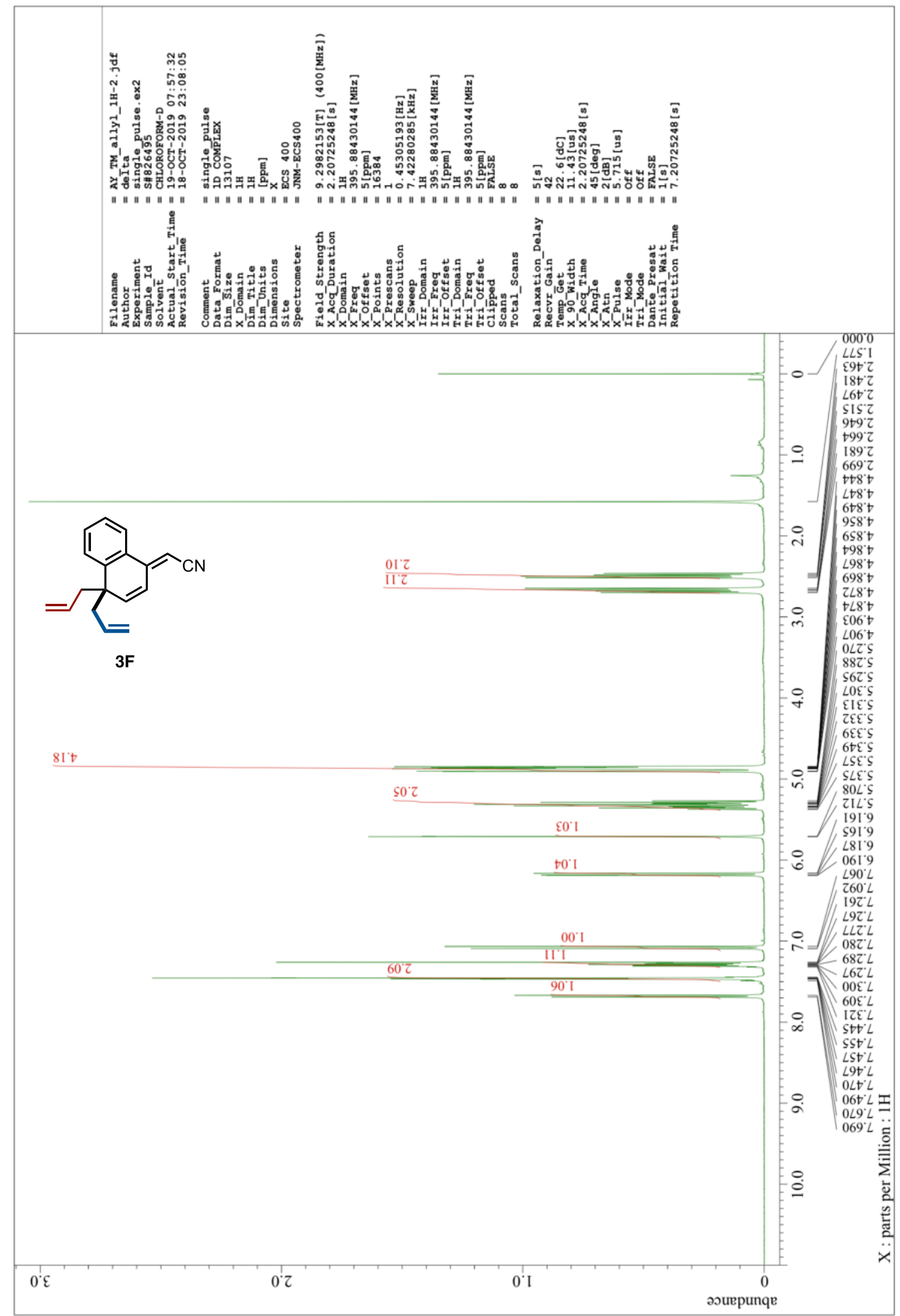


${ }^{13} \mathrm{C}$ NMR of $\mathbf{3 F}\left(101 \mathrm{MHz}, \mathrm{CDCl}_{3}\right)$

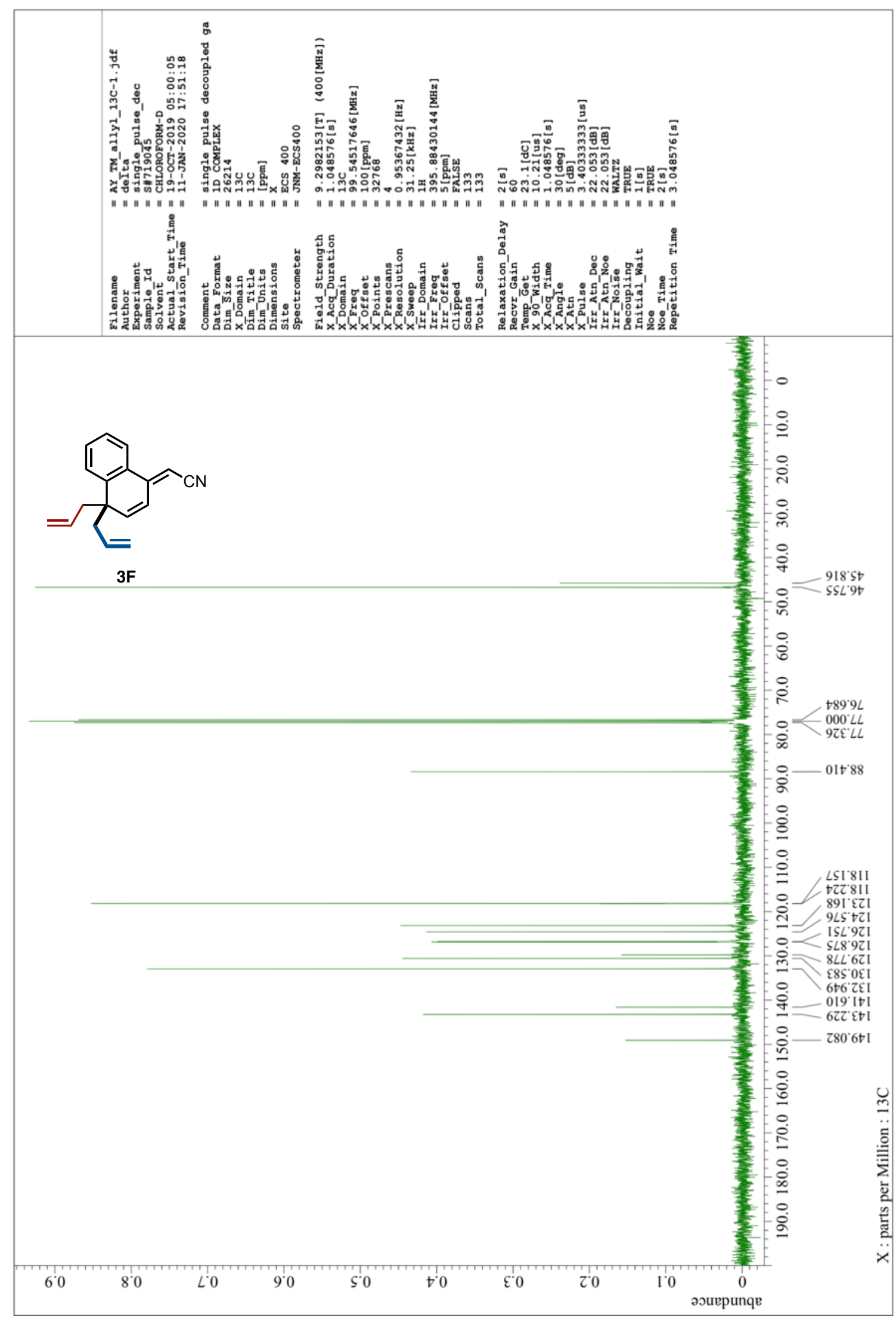

S66 
${ }^{1} \mathrm{H}$ NMR of $\mathbf{3 G}\left(400 \mathrm{MHz}, \mathrm{CDCl}_{3}\right)$

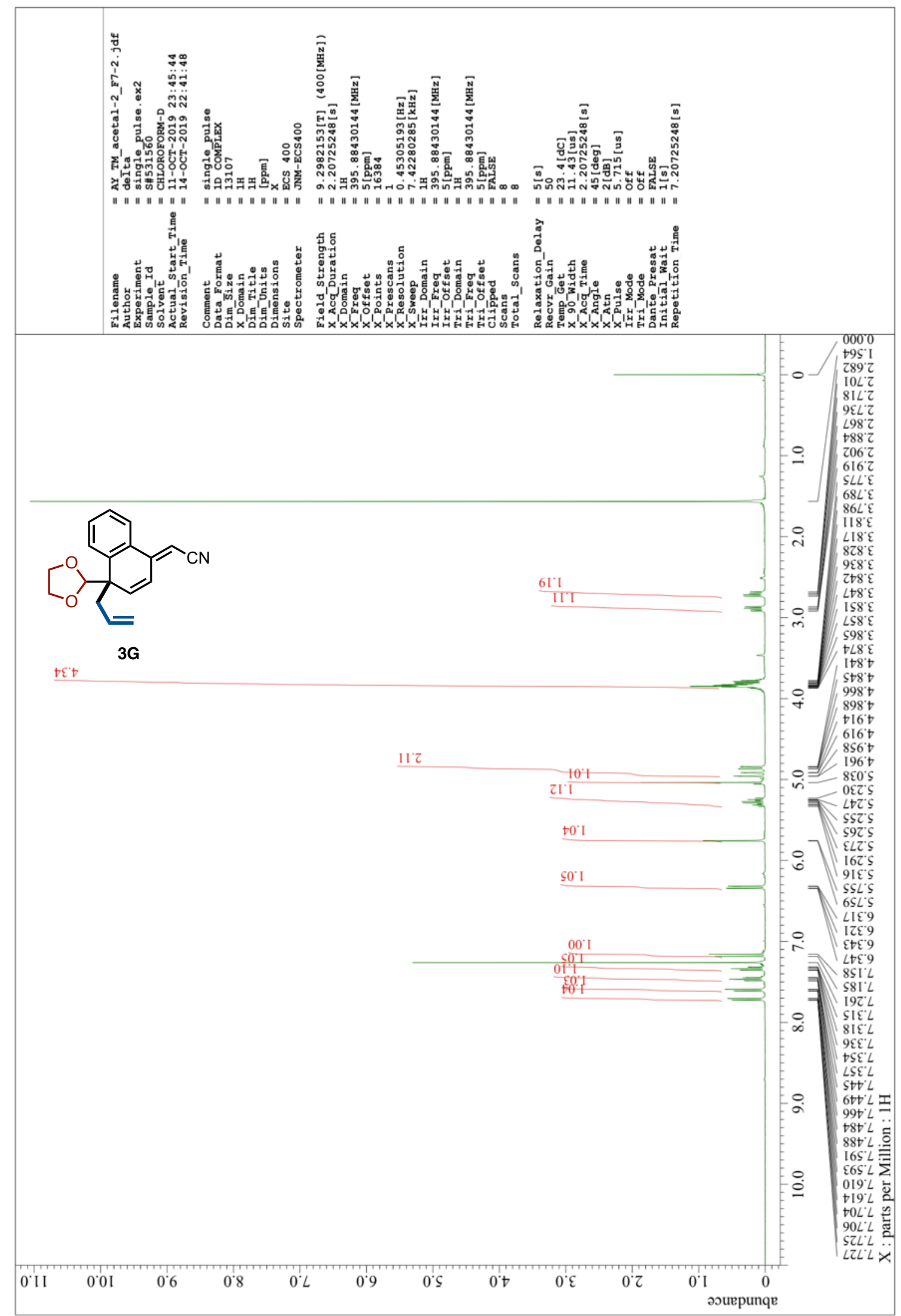


${ }^{13} \mathrm{C}$ NMR of $3 G\left(101 \mathrm{MHz}, \mathrm{CDCl}_{3}\right)$

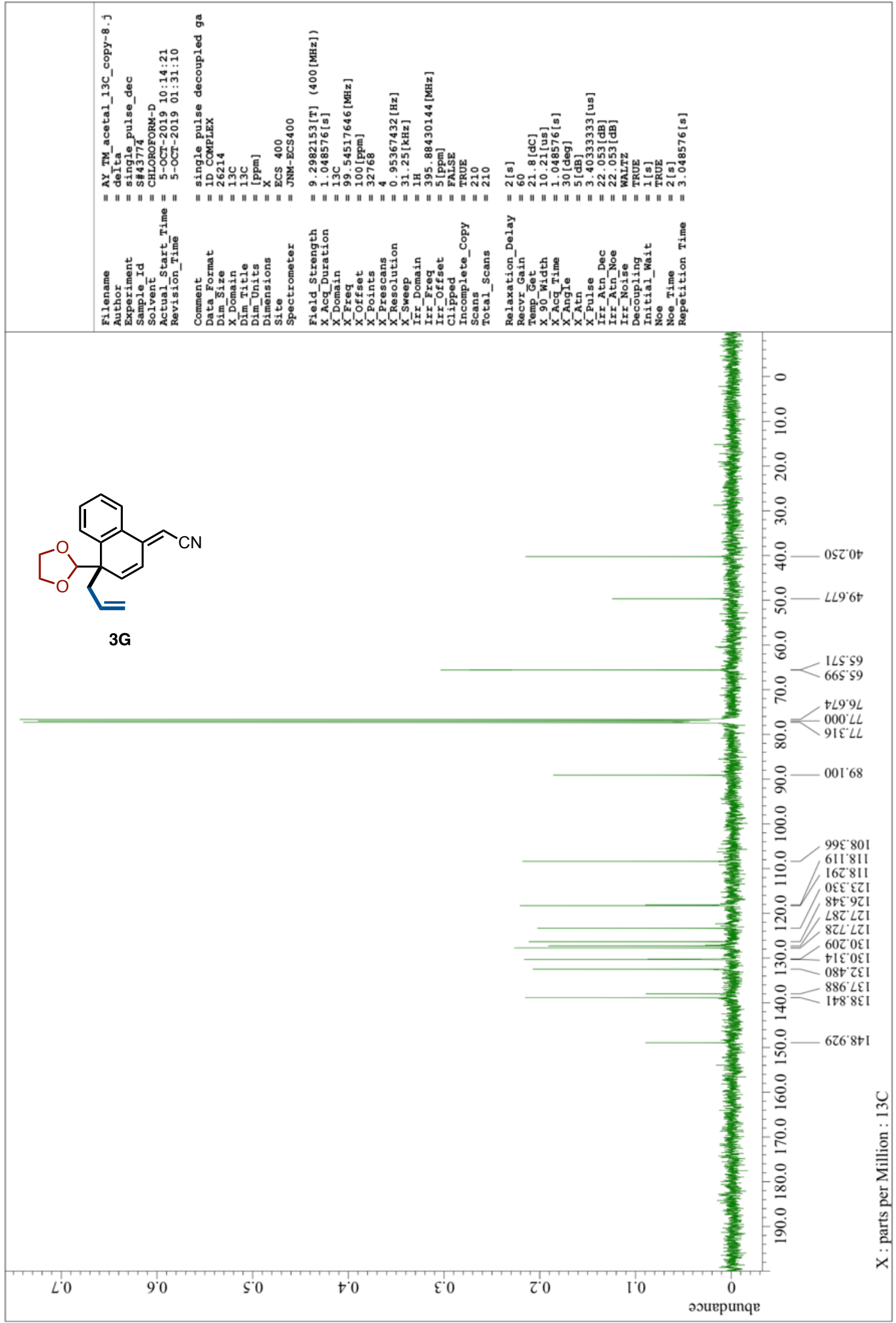


${ }^{1} \mathrm{H}$ NMR of $\mathbf{3 H}\left(400 \mathrm{MHz}, \mathrm{CDCl}_{3}\right)$

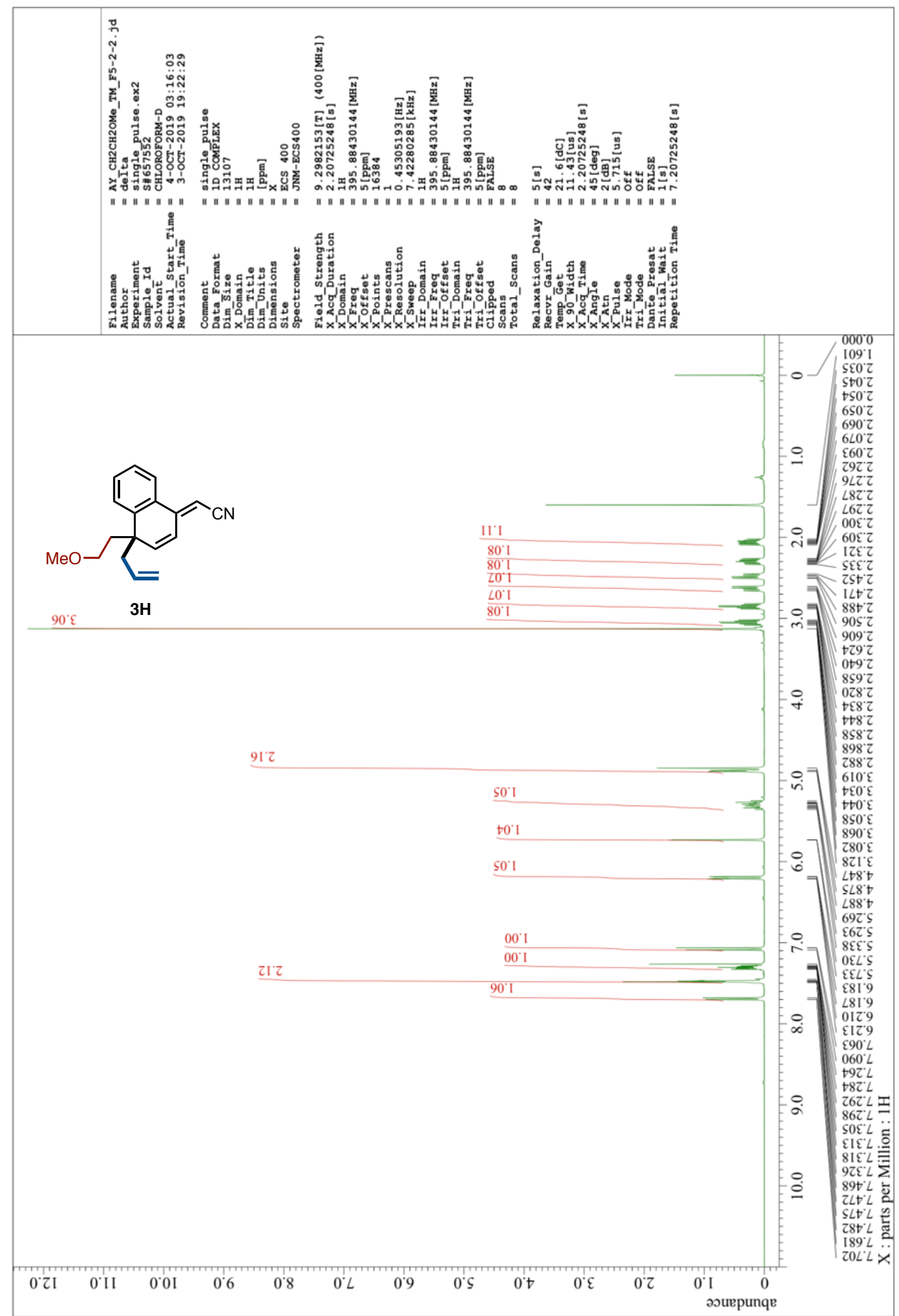


${ }^{13} \mathrm{C}$ NMR of $\mathbf{3 H}\left(101 \mathrm{MHz}, \mathrm{CDCl}_{3}\right)$

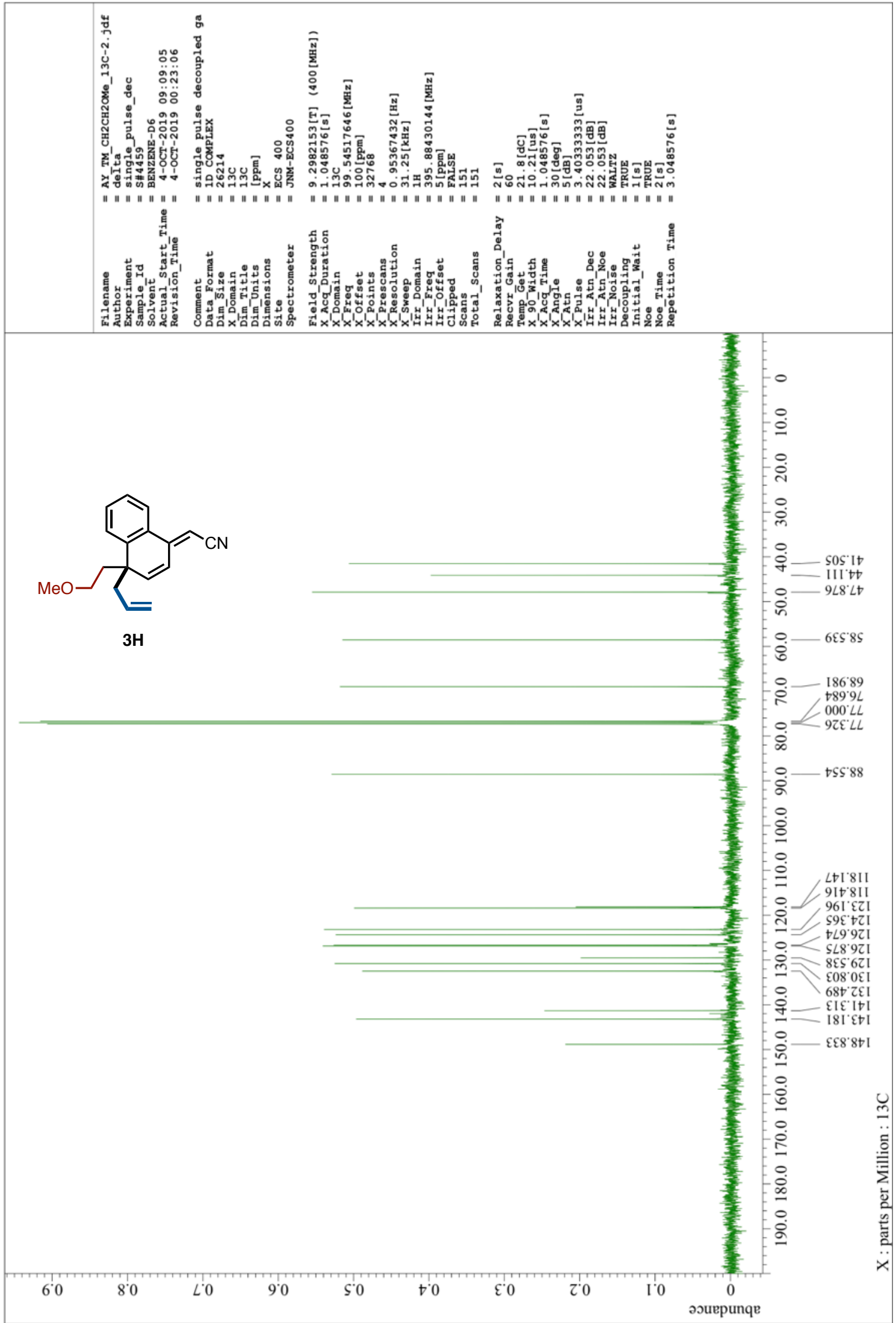


${ }^{1} \mathrm{H}$ NMR of 3I $\left(400 \mathrm{MHz}, \mathrm{CDCl}_{3}\right)$

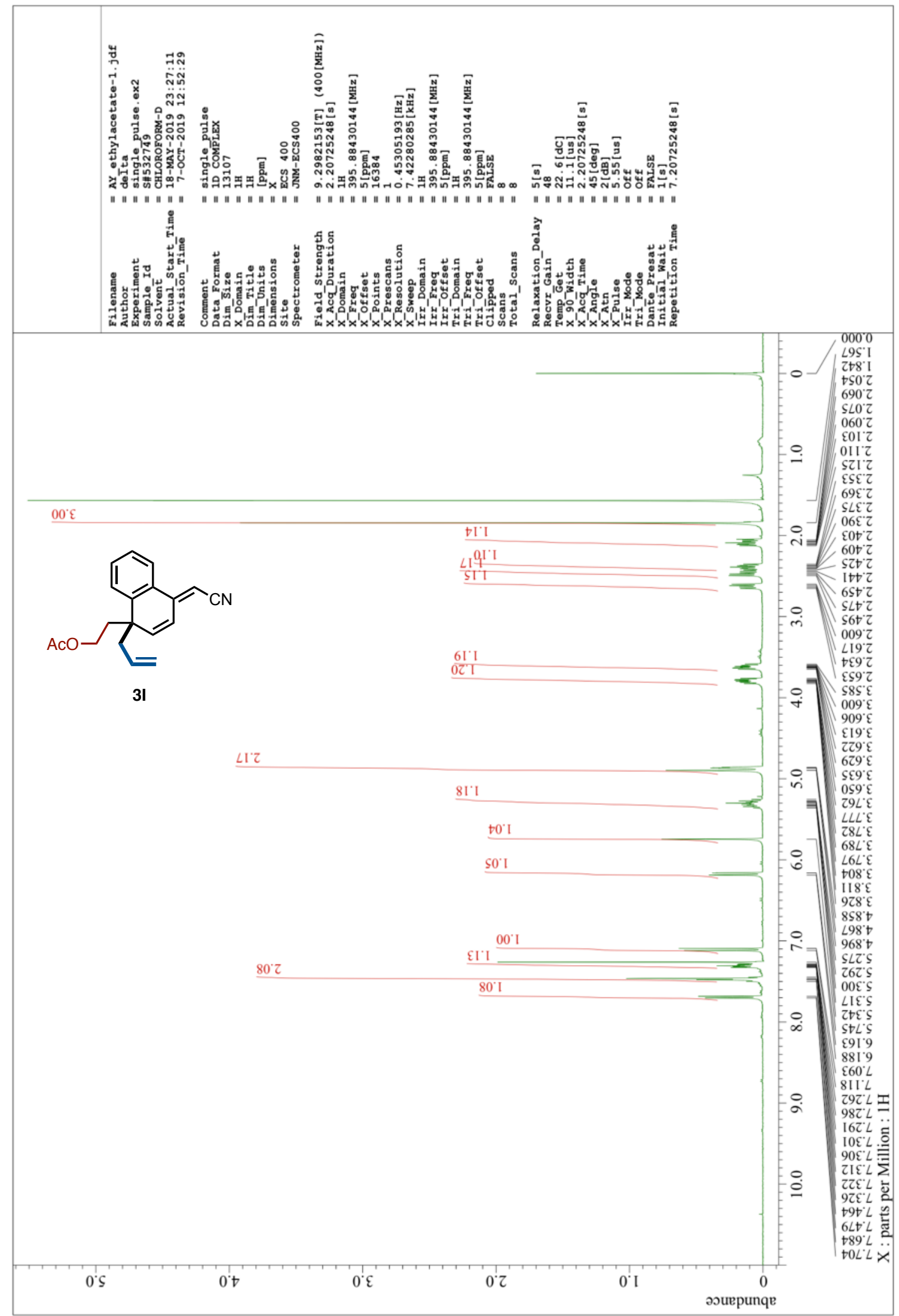


${ }^{13} \mathrm{C}$ NMR of $3 \mathbf{I}\left(101 \mathrm{MHz}, \mathrm{CDCl}_{3}\right)$

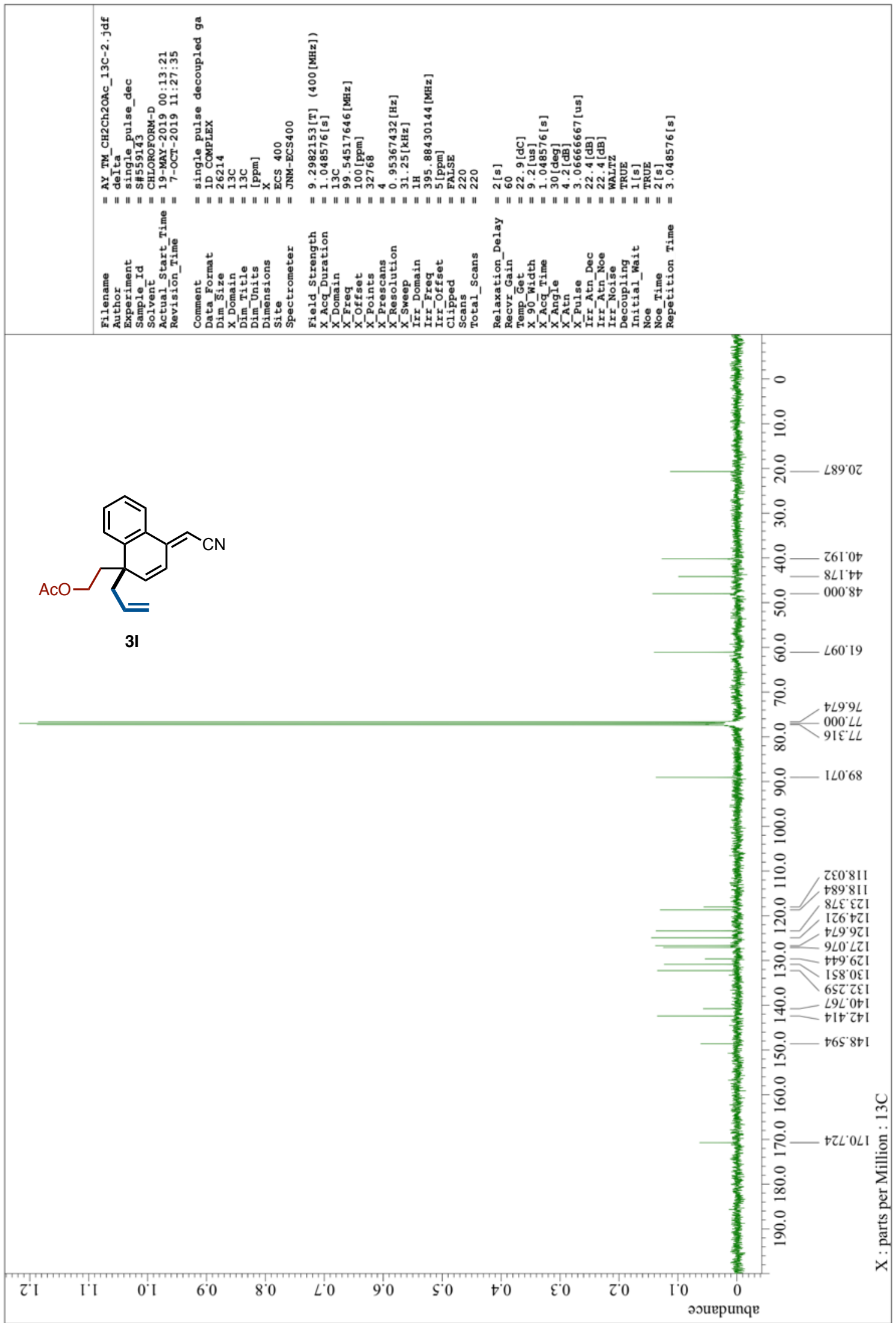


${ }^{1} \mathrm{H}$ NMR of 3J (400 MHz, $\left.\mathrm{CDCl}_{3}\right)$

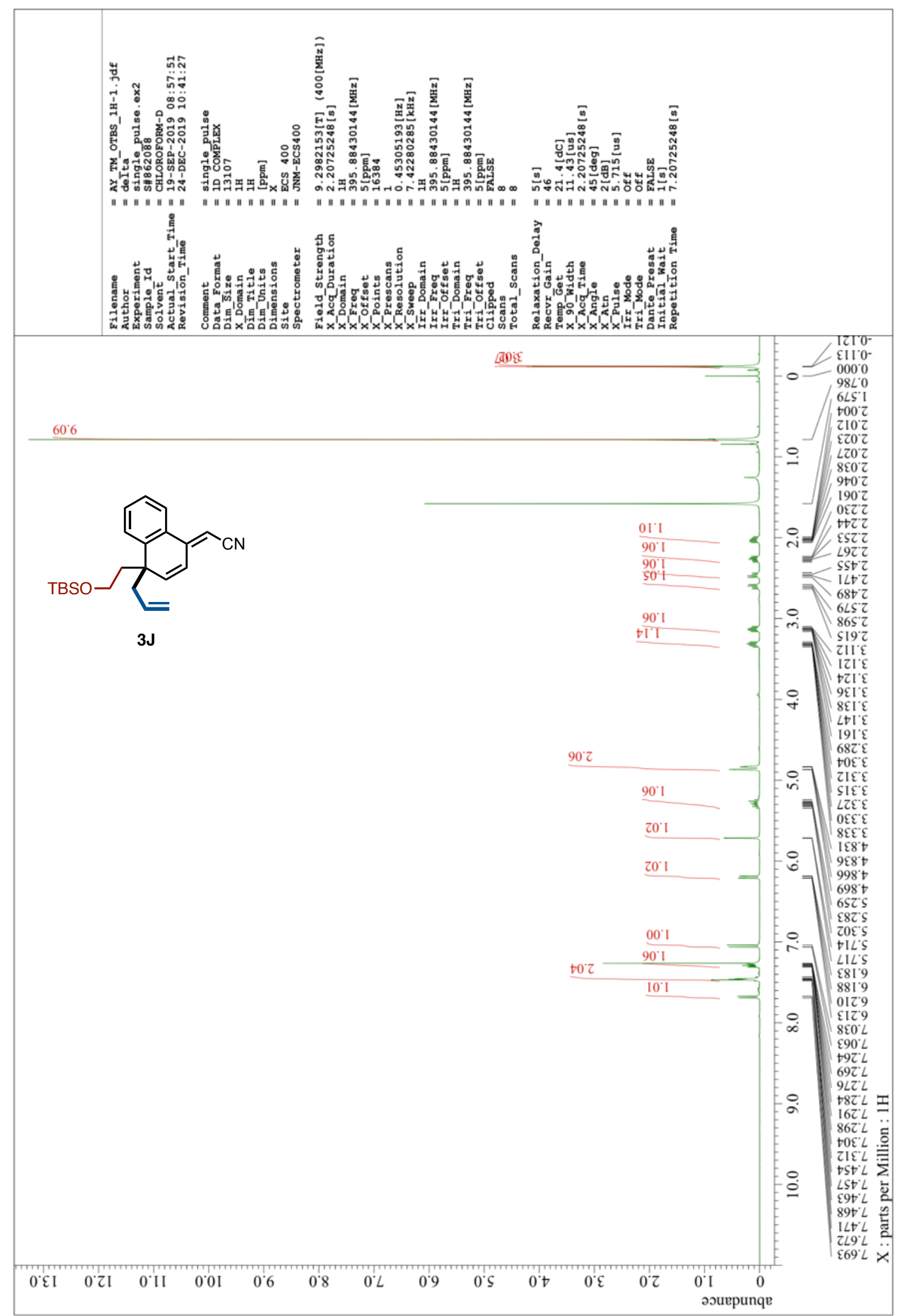


${ }^{13} \mathrm{C}$ NMR of 3J $\left(101 \mathrm{MHz}, \mathrm{CDCl}_{3}\right)$

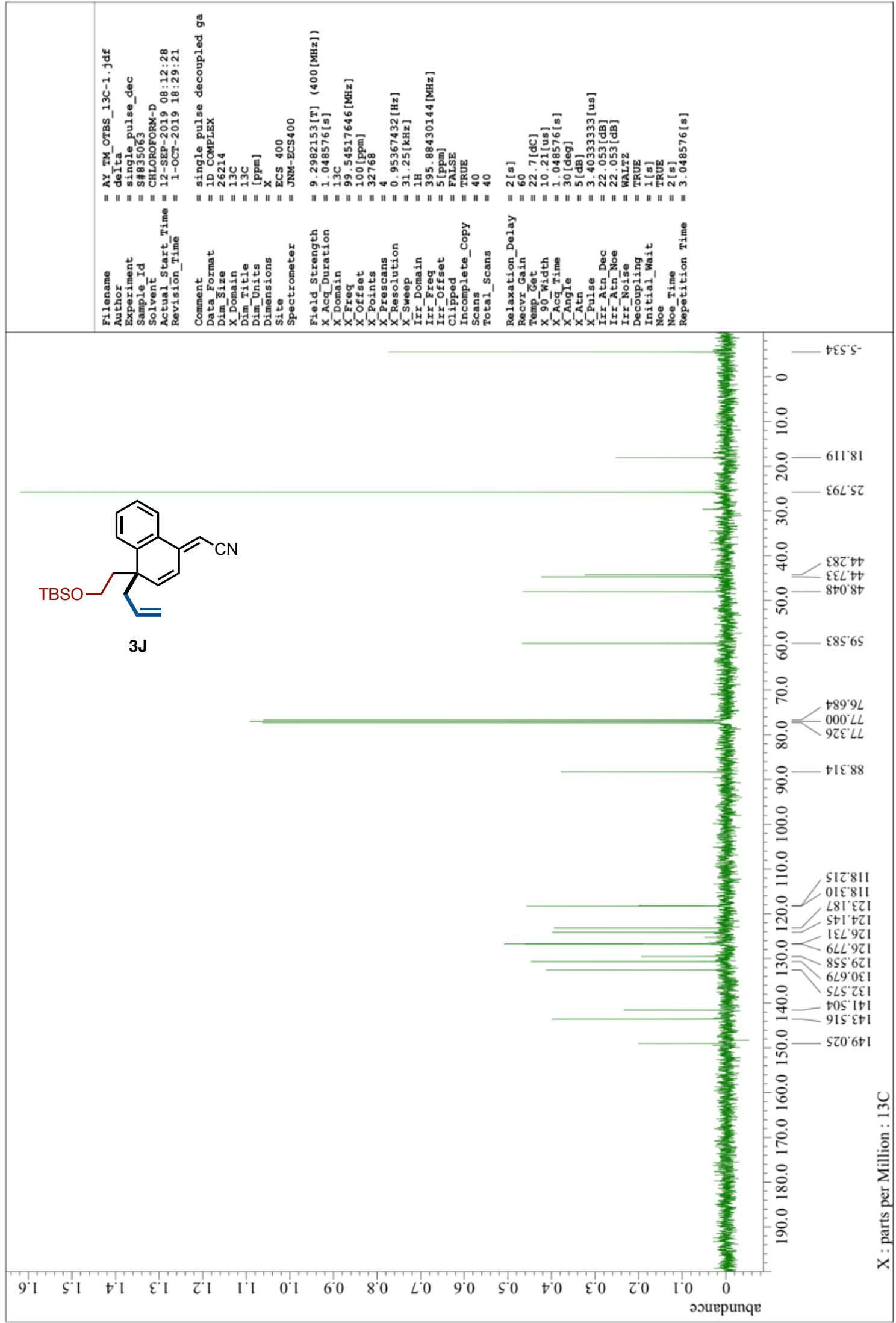


${ }^{1} \mathrm{H}$ NMR of $5\left(400 \mathrm{MHz}, \mathrm{CDCl}_{3}\right)$

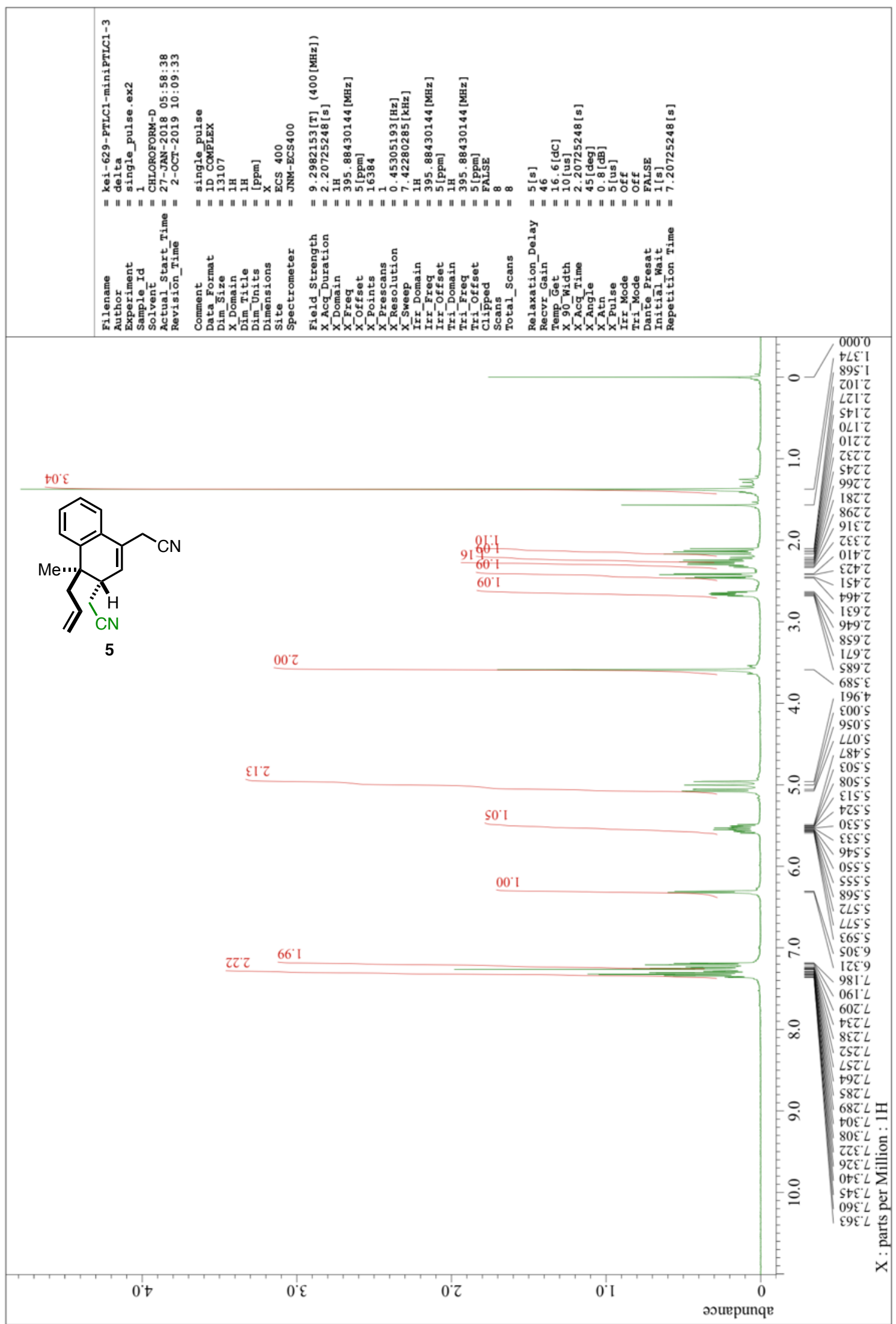


${ }^{13} \mathrm{C}$ NMR of $5\left(101 \mathrm{MHz}, \mathrm{CDCl}_{3}\right)$

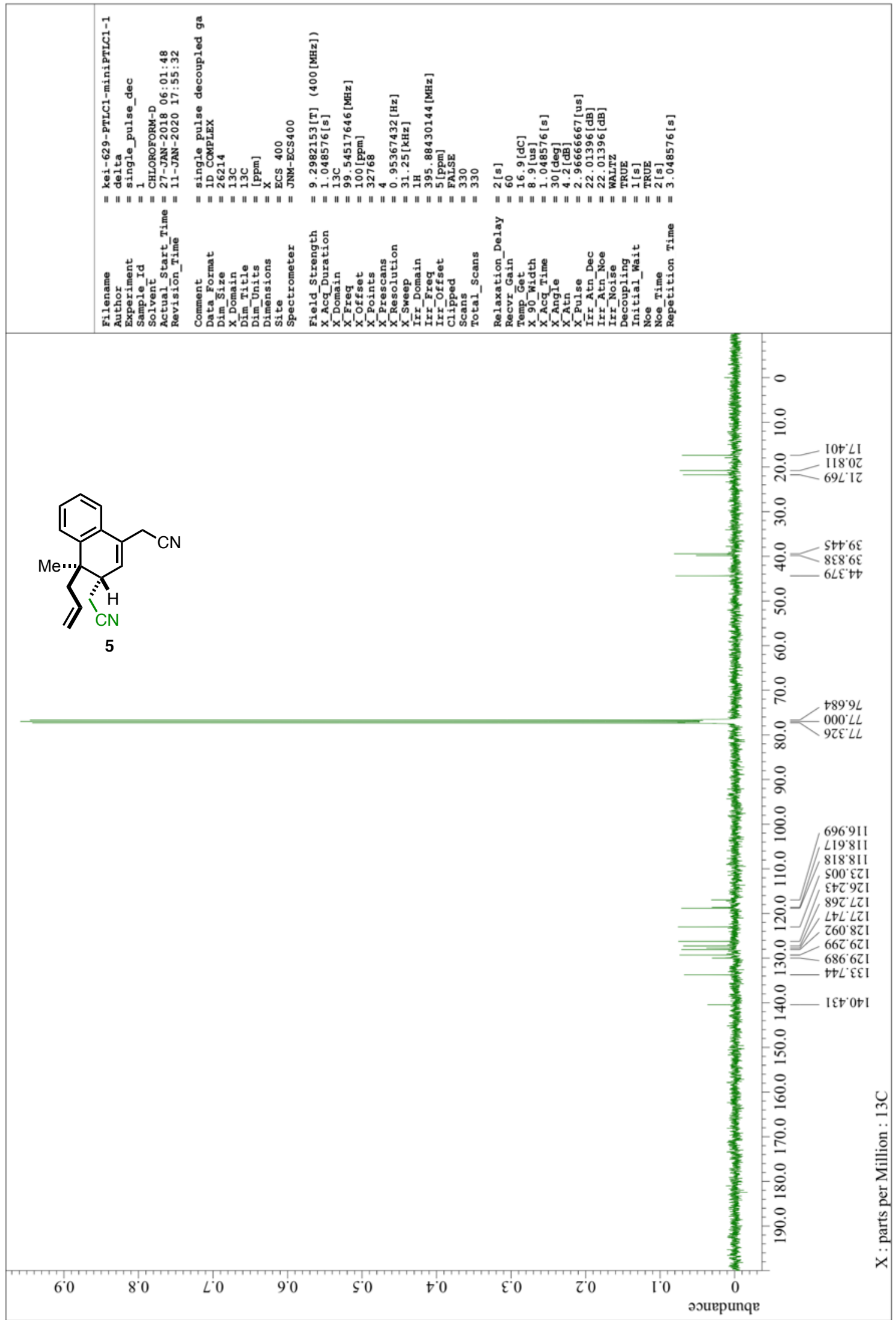


${ }^{1} \mathrm{H}$ NMR of $6\left(400 \mathrm{MHz}, \mathrm{CDCl}_{3}\right)$

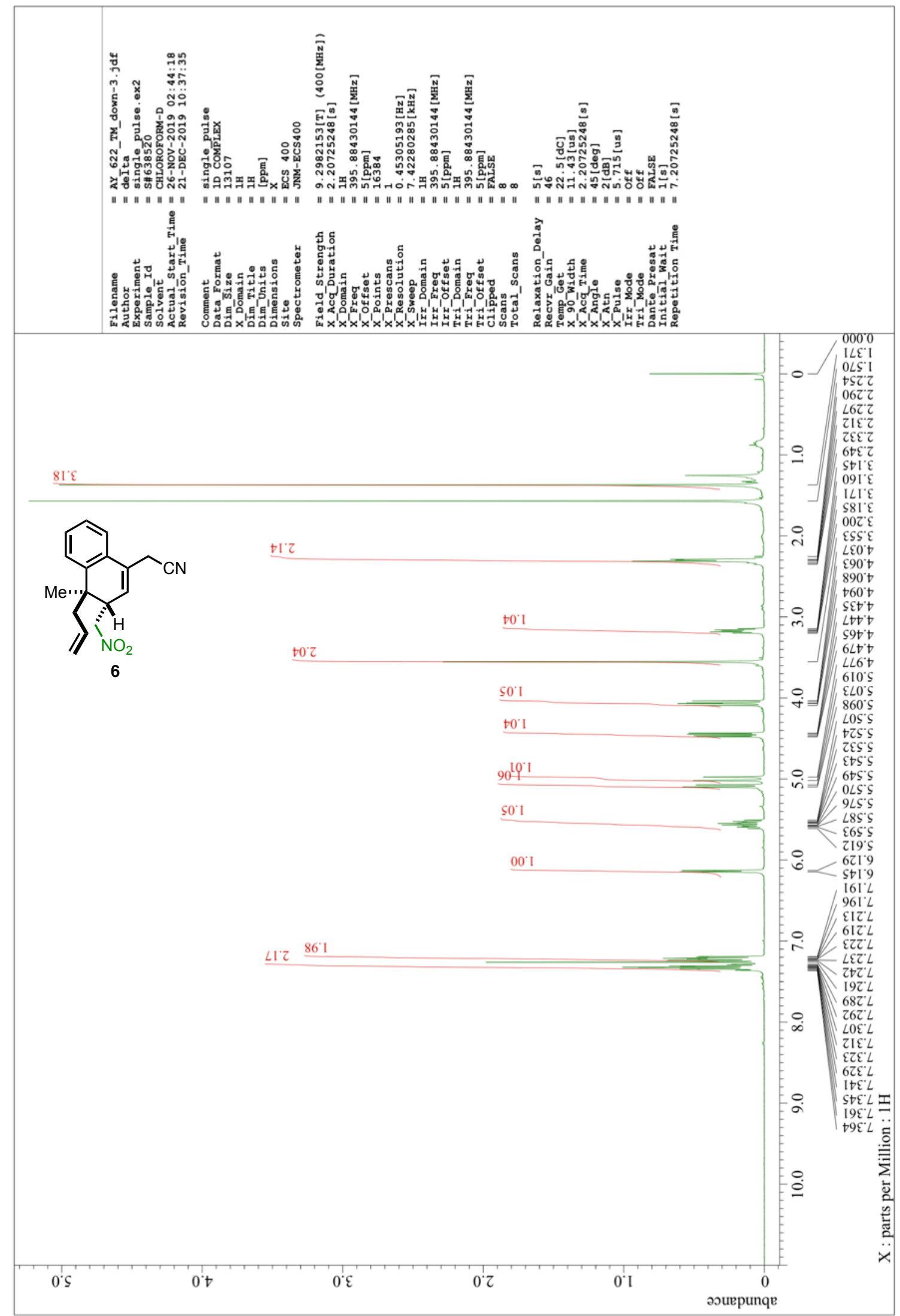


${ }^{13} \mathrm{C}$ NMR of $6\left(101 \mathrm{MHz}, \mathrm{CDCl}_{3}\right)$

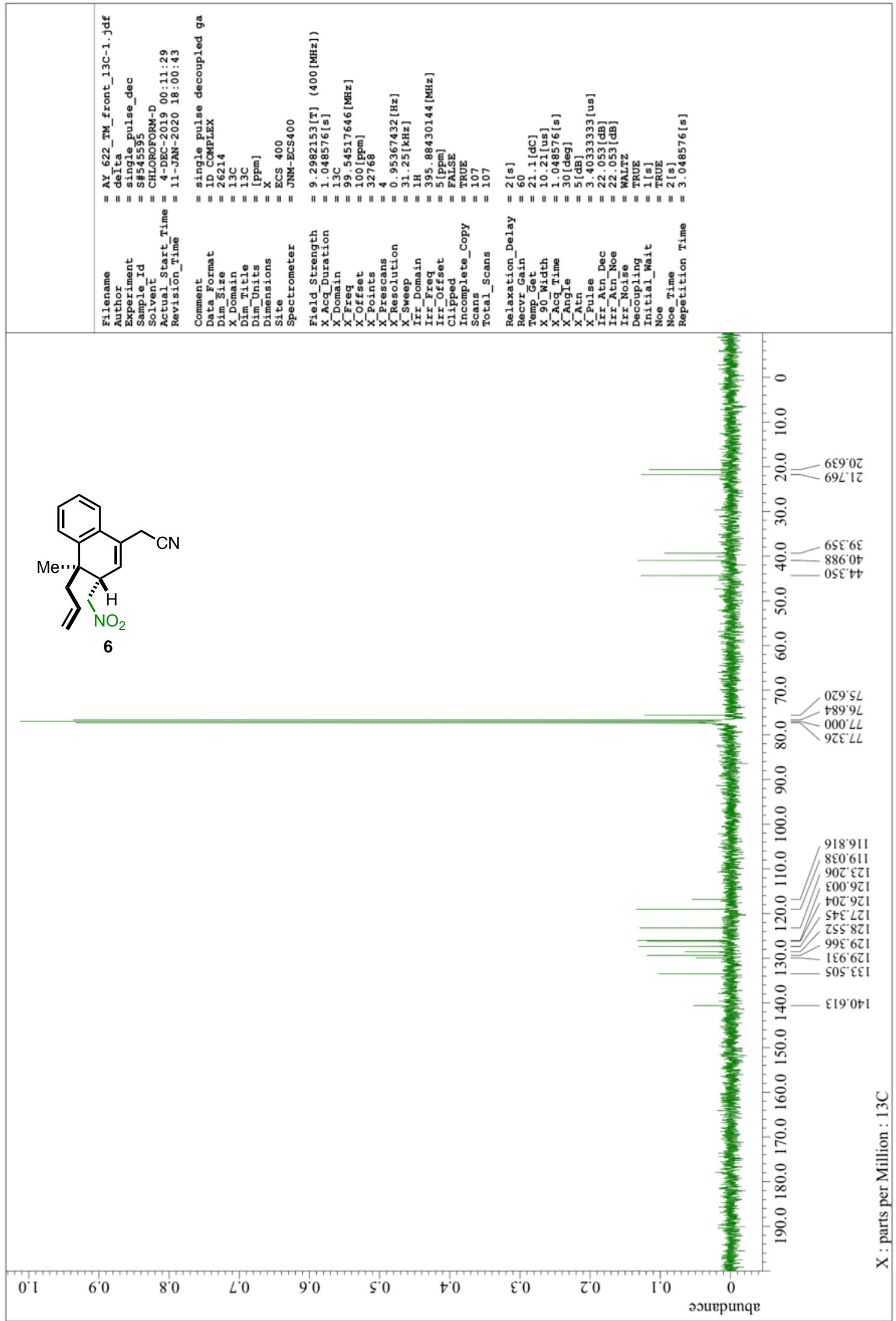


${ }^{1} \mathrm{H}$ NMR of 6' $\left(400 \mathrm{MHz}, \mathrm{CDCl}_{3}\right)$

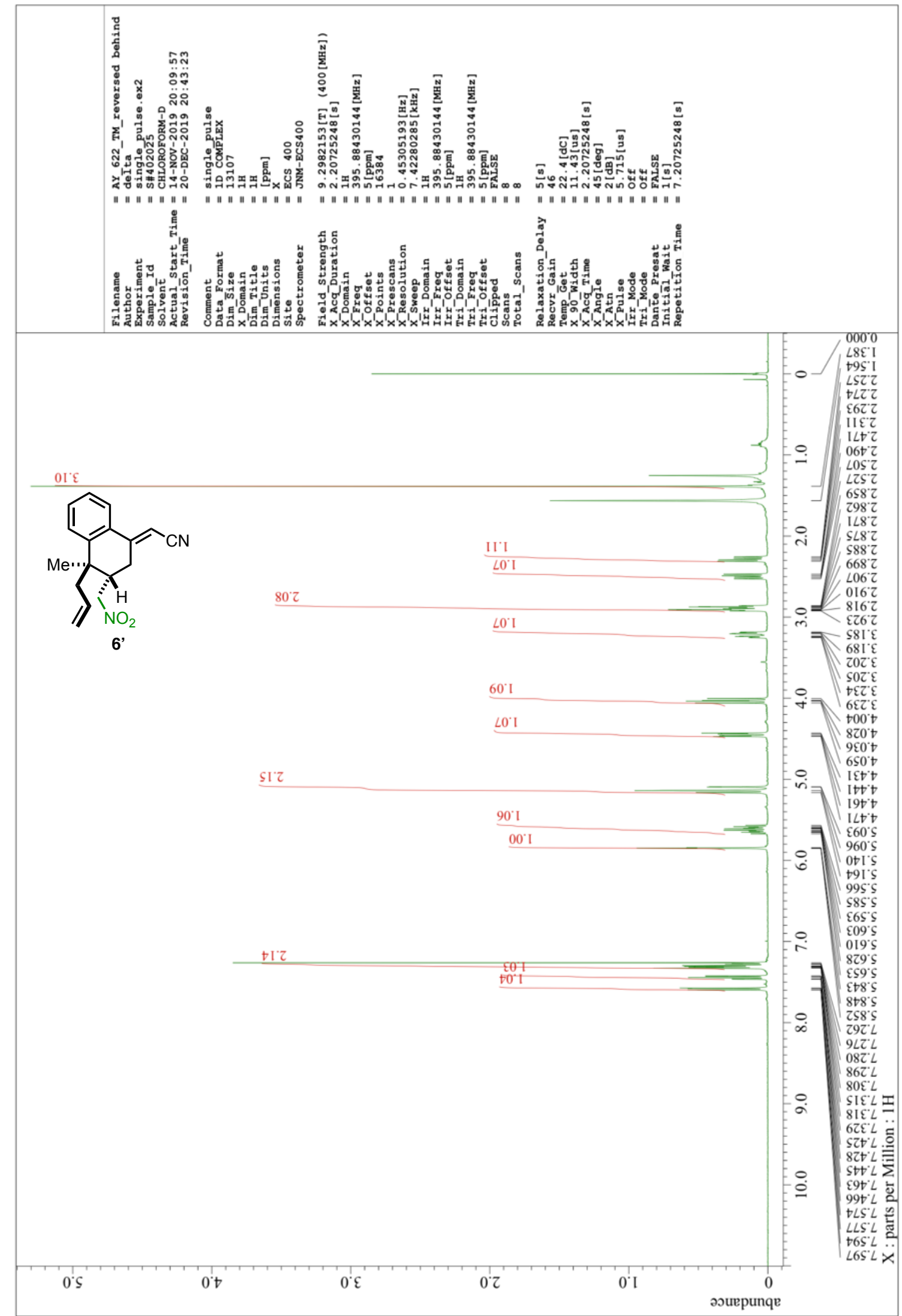


${ }^{13} \mathrm{C}$ NMR of 6' $\left(101 \mathrm{MHz}, \mathrm{CDCl}_{3}\right)$

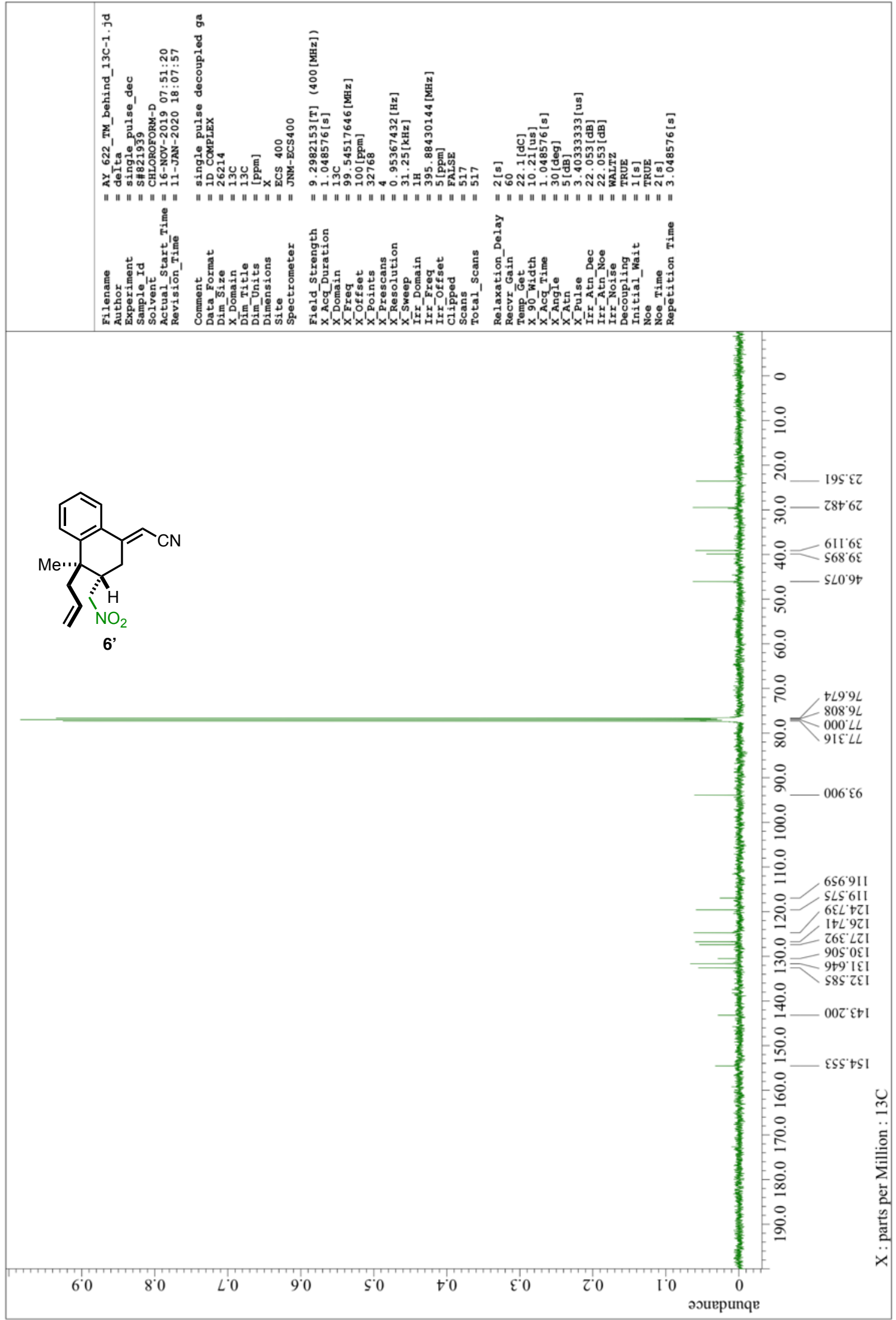


${ }^{1} \mathrm{H}$ NMR of $7\left(400 \mathrm{MHz}, \mathrm{CDCl}_{3}\right)$

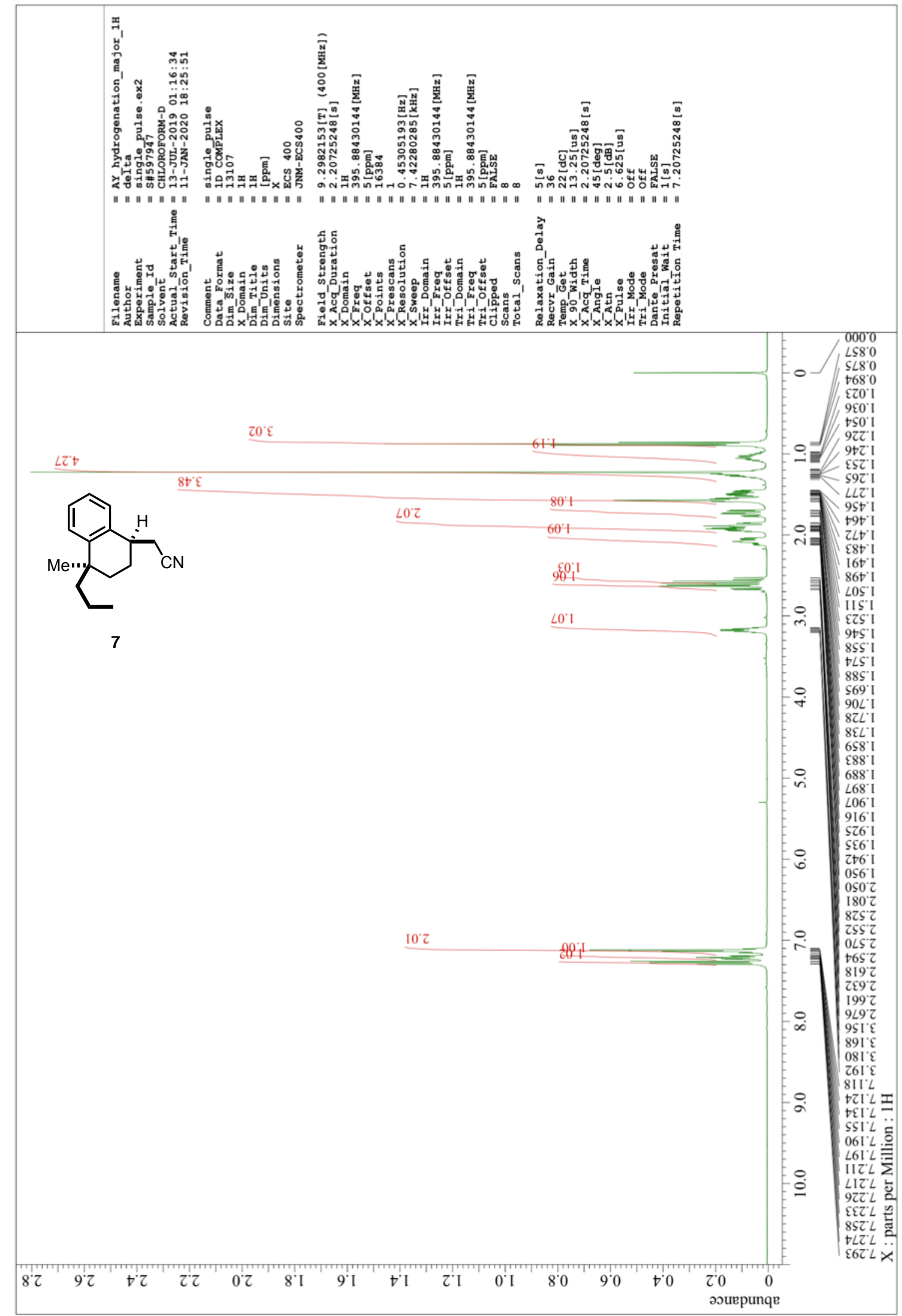


${ }^{13} \mathrm{C}$ NMR of $7\left(101 \mathrm{MHz}, \mathrm{CDCl}_{3}\right)$

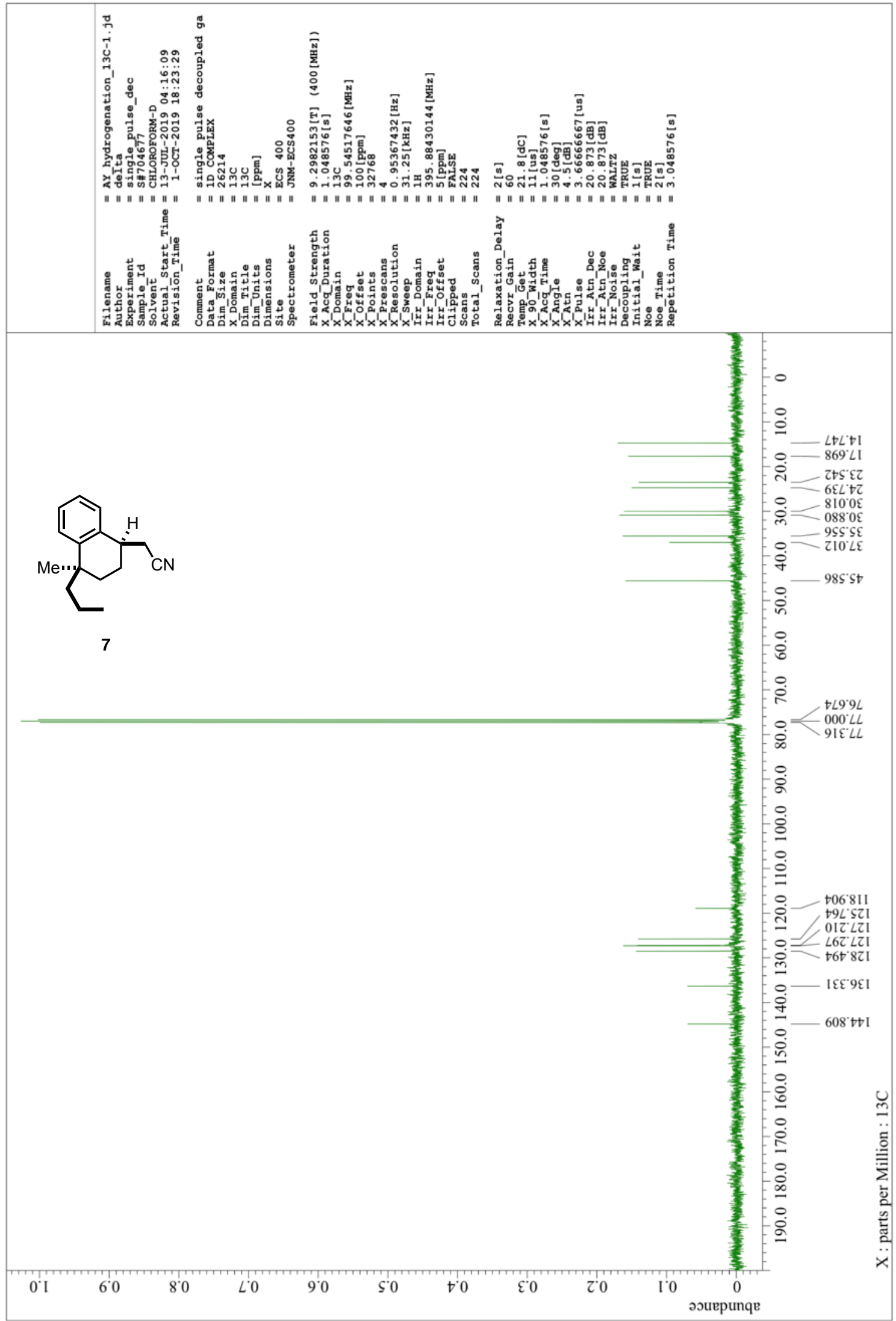


${ }^{1} \mathrm{H}$ NMR of $\mathbf{7}^{\prime}\left(400 \mathrm{MHz}, \mathrm{CDCl}_{3}\right)$

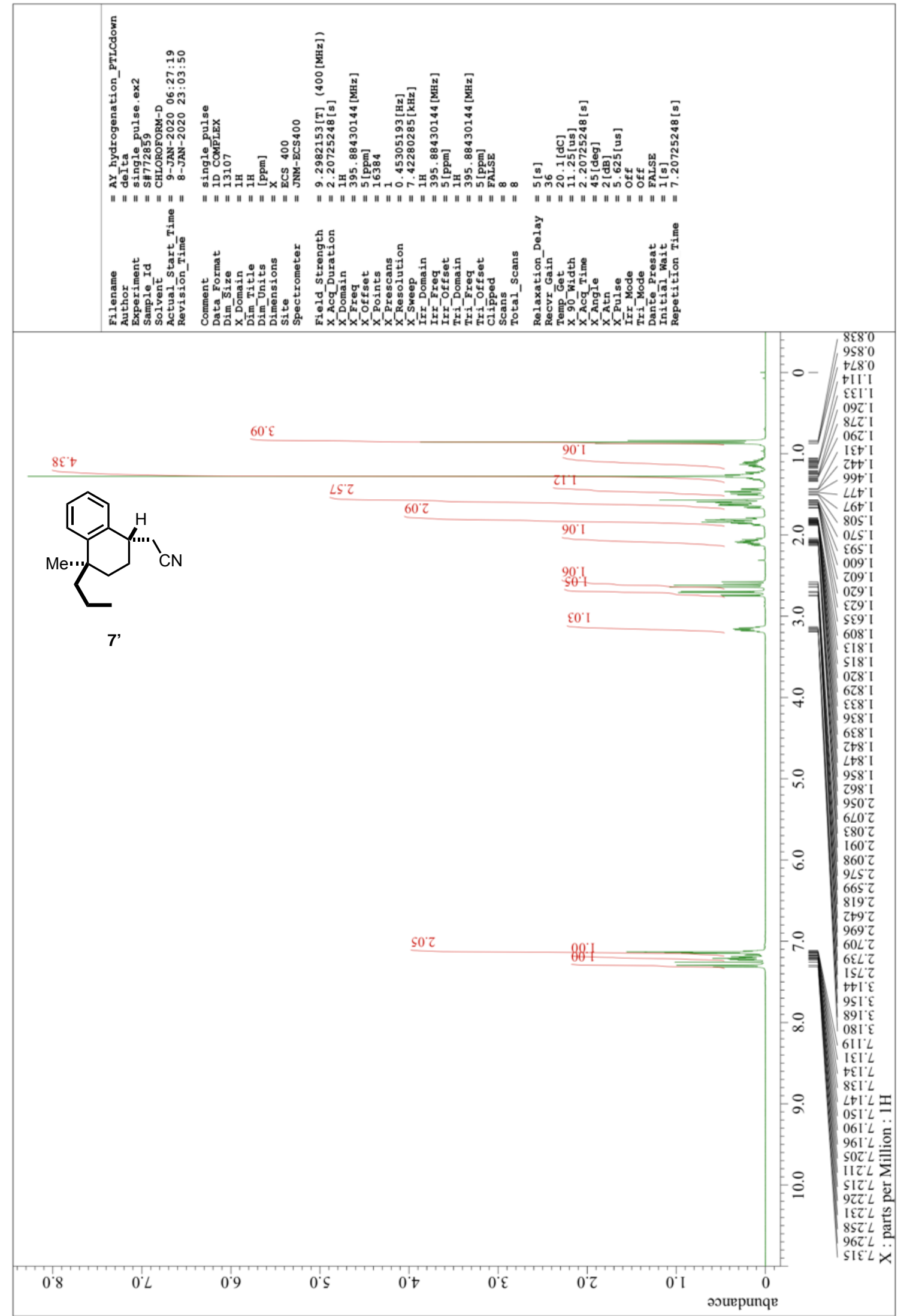


${ }^{13} \mathrm{C}$ NMR of 7 ' (101 MHz, $\left.\mathrm{CDCl}_{3}\right)$

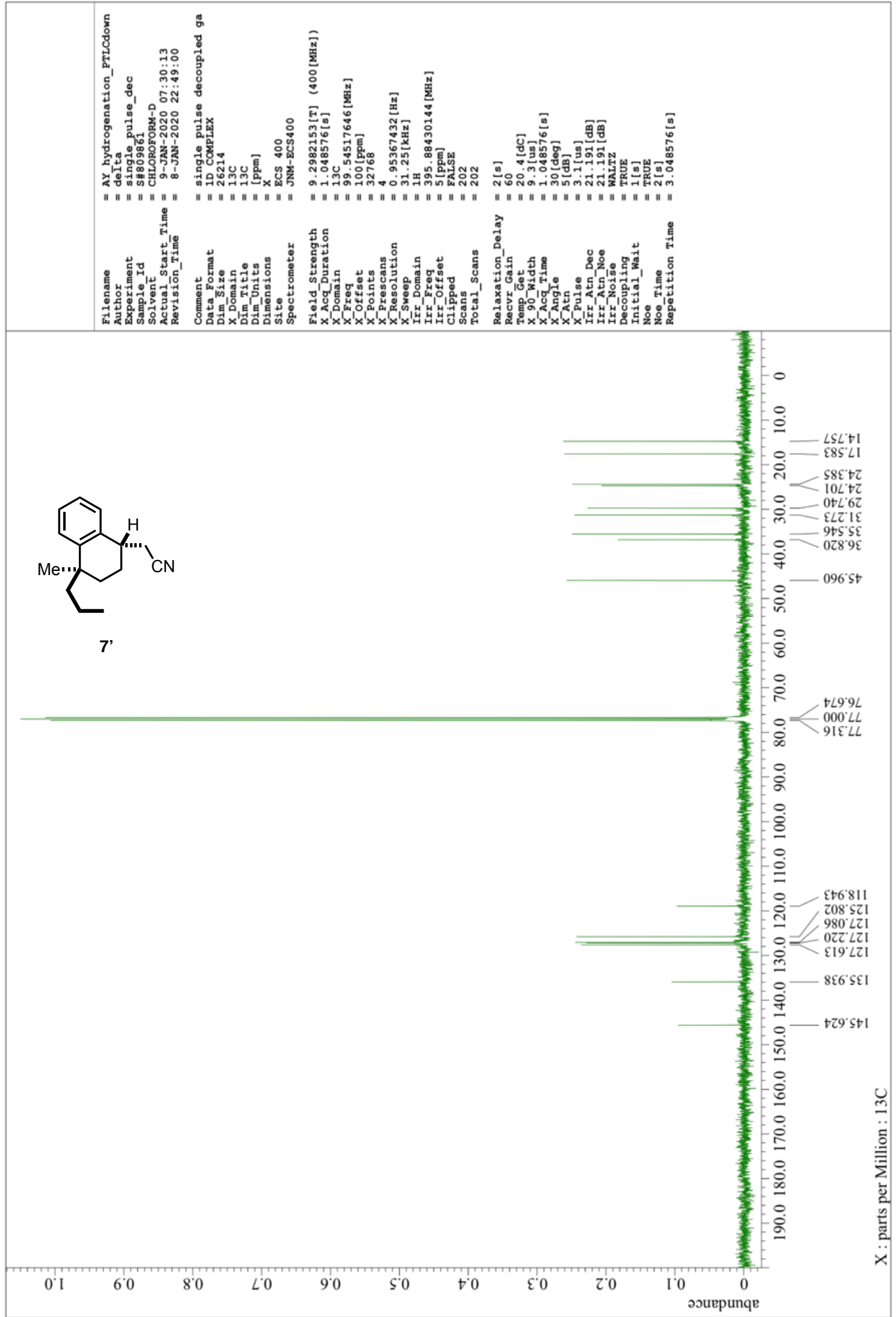


${ }^{1} \mathrm{H}$ NMR of $8\left(400 \mathrm{MHz}, \mathrm{CDCl}_{3}\right)$

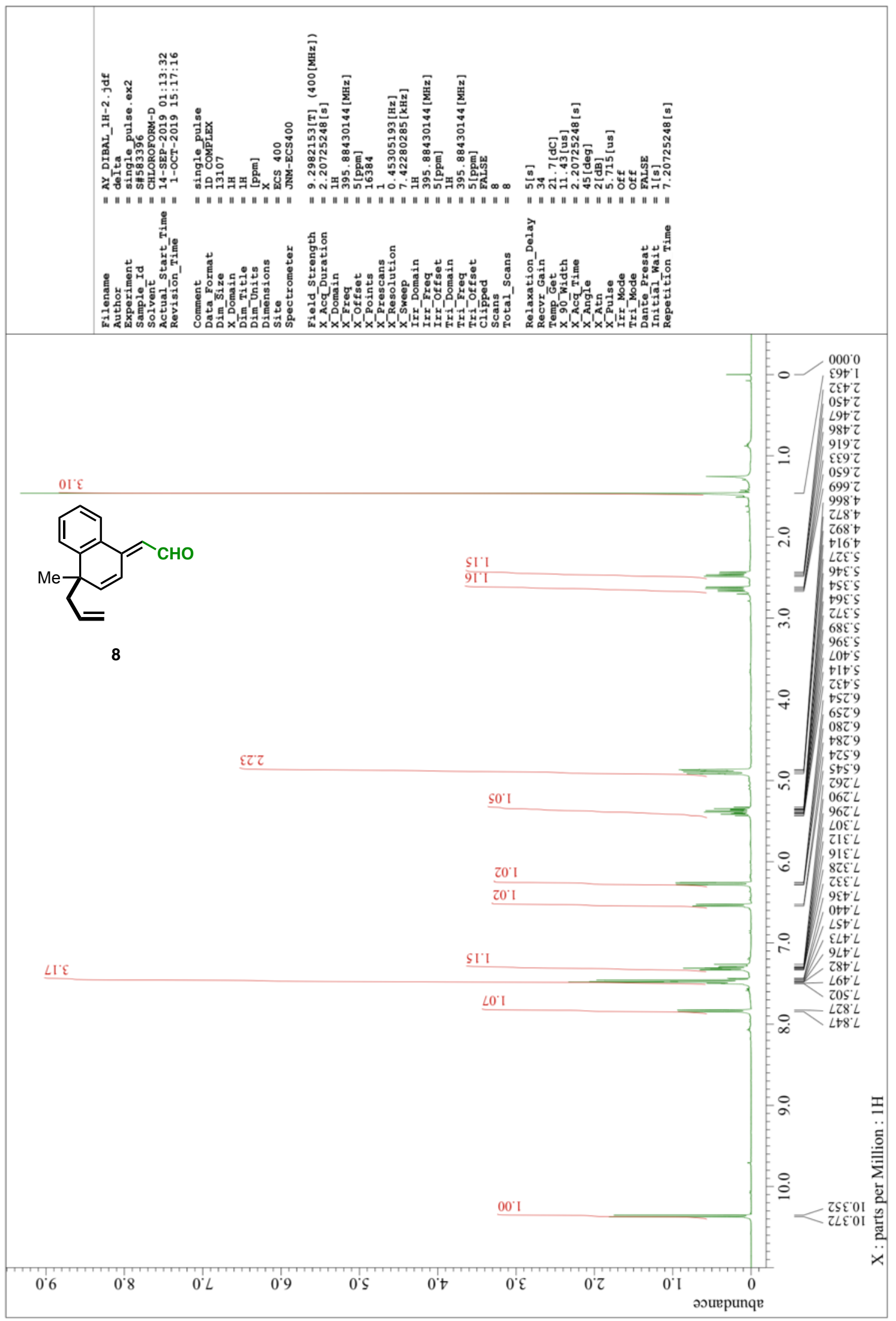




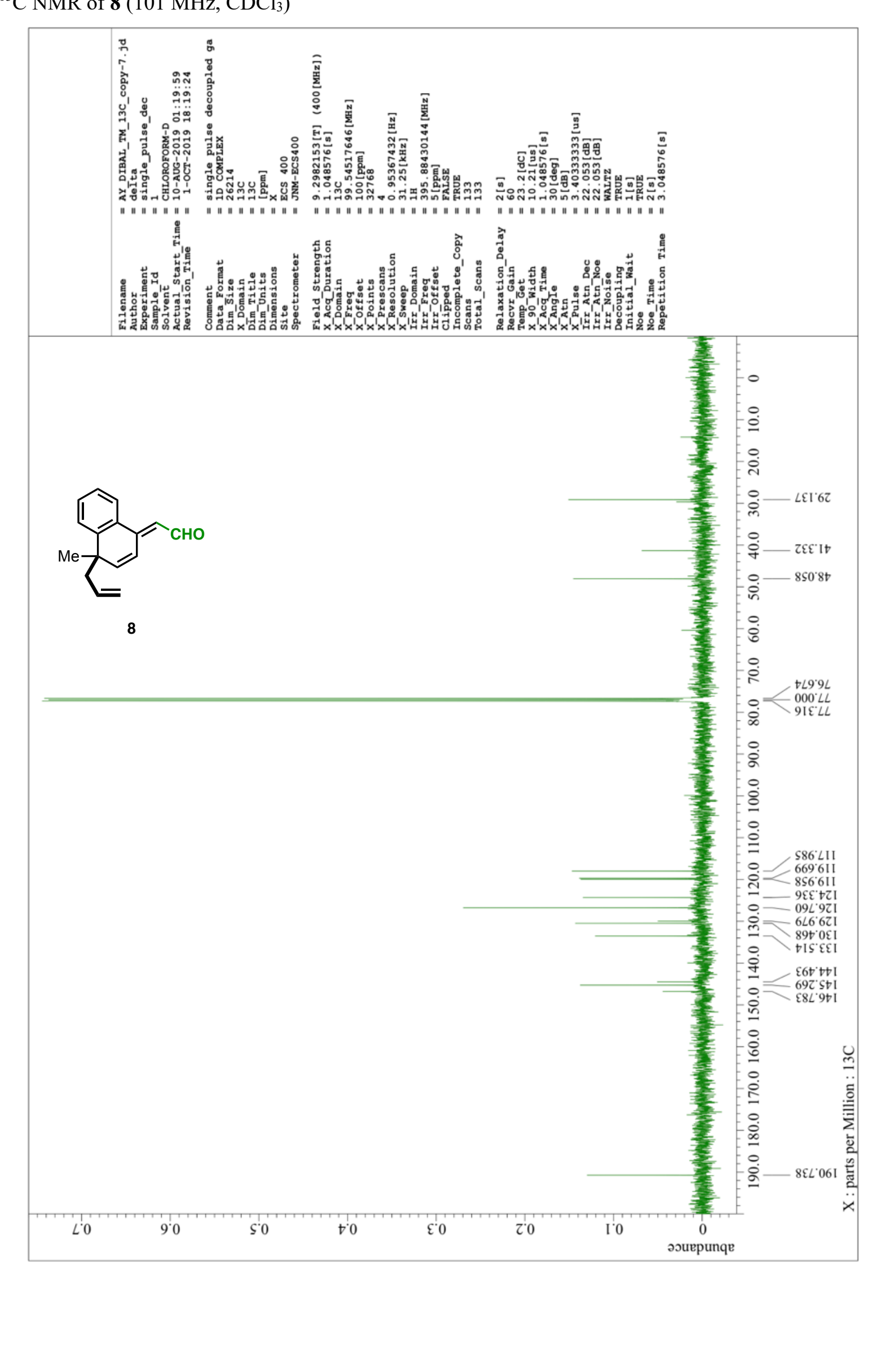

